UNIVERSIDADE DESÃO PAULO

FACULDADE DE CIENCIAS FARMACEUTICAS

Curso de Pós-graduação em

Fármaco e Medicamentos

Área - Elaboração do Medicamento

\title{
ESTUDO FARMACOGNÓSTICO COMPARATIVO DE ESPÉCIES BRASILEIRAS DO GÊNERO Passiflora $L$.
}

PAULO CHANEL DEODATO DE FREITAS

Dissertação para obtenção do grau de MESTRE

Orientador:

Prof. Dr. FERnANDo DE OLIVEIRA 
"O Senhor produziu da terra os medicamentos; o homem sensato não os desprezarā".

Eclesiāstico, 38.4 . 


\section{AGRADECIMENTOS}

Ao Prof.Dr. Fernando de Oliveira, pe la orientação paciente e apoio constante.

A Profá. Assistente Elfriede Marian ne Bacchi, pela amizade e pelas traduções de textos em idioma alemão.

Aos Profs. Drs. Carlos Ruggiero e João carlos de oliveira, da Faculdade de Ciências Agrārias e Veterinärias da UNESP - Jaboticabal, pelo fornecimento do material botânico utilizado neste estudo.

Ao Prof.or. Seizi oga, pelo auxilio e realização dos ensaios farmacológicos.

Aos funcionārios de nossa Faculdade, de modo especial aos do bloco 15, pelo companheirismo destes anos de convivência.

A todos aqueles que de maneira dire ta, ou indiretamente, contribuiram na elaboração deste traba lho. 


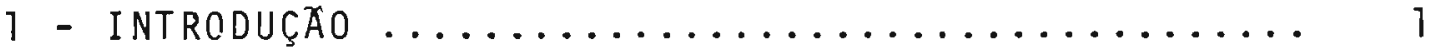

1.1 - Objetivo do Trabalho .............. 3

2 - ReVisAo Bibliografica .................... 4

2.1 - Aspectos Botānicos ................ 4

2.1.1 - Generalidades ............. 4

2.1 .2 - Posição sistemätica ........... 5

2.1 .3 - o gēnero Passiflora L. ......... 5

2.1.4 - Características anatómicas de Passifloraceae Jussieu ......... 17

2.2 - Aspectos Histōricos ............... 18

2.3 - Aspectos Químicos ................. 20

2.4 - Aspectos Farmacológicos ............. 26

3 - materiais e metodos ....................... 29

3.1 - Material Botānico ................. 29

3.1 .1 - Cortes histológicos .......... 29

3.2 - Estudo dos Extratos f1uidos ........... 32

3.2.1 - Preparo dos extratos ......... 32

3.2.2 - Anālise cromatogrāfica dos extratos .................... 32

3.2.2.1 - obtenção da fração flavonoidica dos extratos ............. 32 
Pàg.

3.2.2. - Cromatografia em camada delgada das frações flavnoídicas .......... 33

3.2.2.3 - obtenção da fração alcaloídica dos extratos.... 34

3.2.2.4 - Cromatografia em camada delgada das frações

a lcaloidicas .......... 35

3.2.3 - Determinação de flavonōides em extrato de P.alata Dryand. por densitometria em camada delgada ...

3.2.4 - Determinação de alcalöides em ex trato de $\underline{\text { Palata }}$ Dryand. por anā lise densitométrica em camada de 1 gada $\ldots \ldots \ldots \ldots \ldots \ldots \ldots \ldots$

3.3 - Ensaios Farmacológicos de Extrato seco de . alata Dryand. ................. 37

3.3 .1 - Animais e tratamento ......... 37

3.3.2 - Tempo de sono induzido pelo pentobarbitat sodico ............ 37

3.3 .3 - Convulsão por estricnina ....... 38

3.3 .4 - Convulsão por pentetrazol ...... 38

3.3 .5 - Atividade motora espontānea ..... 38

3.3.F - Toxicidade aguda ............... 39

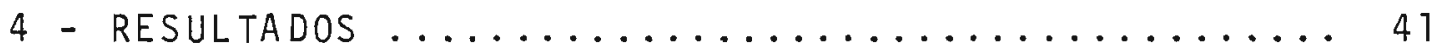

$4.1-$ Botānica ....................... 41

4.1 .1 - Passiflora a 1 ata Dryander ...... 41 
Pāg.

4.1 .2 - Passiflora quadrangularis L..... 54

4.1 .3 - Passiflora edul is sims......... 65

4.1 .4 - Passiflora incarnata L. ........ 78

4.2 - Química ...................... 89

4.2.1 - Anālise cromatogrāfica da fração flavonoidica dos extratos fluidos das diversas espécies de $\underline{\text { Pas }}$ siflora L. .................. 89

4.2.2 - Anāilise cromatogrāfica em camada del gada da fração alcaloỉdica dos extratos de Passiflora L......... 90

4.2.3 - Teores flavonoidico e alcaloidi co do extrato seco de $\underline{P}$. alata Dryand.................... 91

4.2.3.7 - Determinação dos flavonóides por anālise densitométrica ......... 91

4.2.3.2 - Determinação de alcalóides harmānicos por densitometria em placa cromatogrāfica ......... 91

4.3 - Farmacologia .................... 94

4.3.1 - Atividade farmacológica do extra to de P.alata Dryand. ............ 94

4.3.1.1 - Tempo de sono induzido pelo pentobarbital ..... 94

4.3.1.2 - Convulsão por estricni na ................ 96

4.3 .1 .3 - Convulsão por pentetra zol $\ldots \ldots \ldots \ldots \ldots \ldots .98$ 
Pàg.

$$
\begin{aligned}
& \text { 4.3.1.4 - Atividade motora espon } \\
& \text { tānea .............. } 100 \\
& \text { 4.3.1.5 - Toxicidade aguda ...... } 100
\end{aligned}
$$

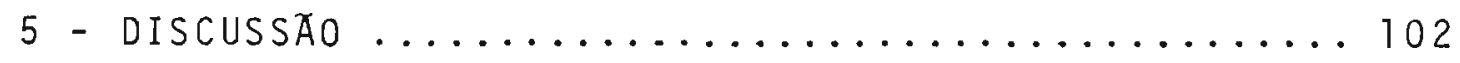

5.1 - Botānica ......................... 102

5.1 .1 - Caracterização macroscópica ..... 102

5.1 .2 - Caracterização microscópica ...... 104

5.2 - Quimica ........................ 108

5.3 - Farmacologia ................... 115

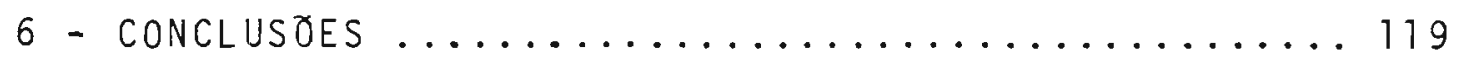

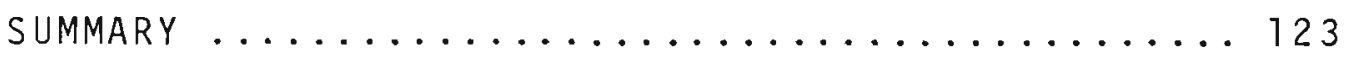

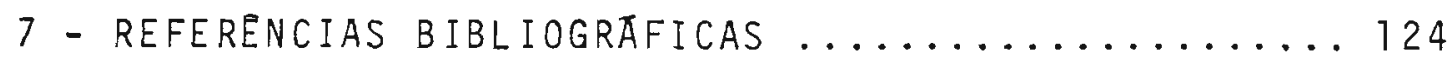




\section{1 - INTRODUÇAOO}

Recorrer à natureza em busca do que - alimente e o cure, é tarefa que o homem desde cedo apren deu, e em momento algum de sua existência, deixou de fazé10. Variou, é fato, a forma da utilização, ou mesmo da ex ploração, principalmente, do reino vegetal. o que era, nos primōrdios e atē anos atrās, busca empīrica, tornou-se com - progresso, pesquisa sistemātica de recursos naturais.

Só por volta de 1810 teve início o isolamento de principios ativos de origem vegetal e a entrada do sēculo passado, foi marcada pelo advento da moder na indūstria da sintese química.

Ainda assim, a contribuição do reino vegetal à medicina clāssica manteve-se presente. Entra ram para ficar consagrados como recursos insubstituiveis na terapêutica:- o öpio:- látex dessecado de papaver somniferum L.; as folhas da dedaleira:- Digitalis purpurea L.; as rai zes de Rauvolfia serpentina Benth., para citar alguns exemplos.

Em 1867, ajuntou-se a esta 1 ista as folhas de Passiflora, utilizadas pela sua ação calmarì em casos de insōnia e irritabilidade ( 3 ) por Phares, a quem é atribuĩda a introdução de Passiflora incarnata L. na terapēutica.

No Brasil, as espécies do gēnero Passiflora L. são conhecidas por "maracujās". 
Algumas são cultivadas por seus fru tos comestiveis, apreciados e consumidos, principalmente, na forma de sucos e refrescos. Passiflora edulis sims for ma flavicarpa Deg. Conhecida vulgarmente por maracujä ama relo, maracujä-mirim ou maracujā de comer representa a for ma mais cultivada em escala comercial. São também difundi das em nosso paîs, embora não na mesma escala:- Passiflora edulis Sims, Passiflora alata Dryander, Passiflora quadran gularis L., Passiflora caerulea L. e Passiflora laurifolia L. (59).

Graças às propriedades sedantes, vā rias farmacopéias incluem entre suas monografias, espēcies deste gênero. Assim, Passiflora incarnata L. consta dos cödigos farmacēuticos da França, Bēlgica, Suiça e Chile. Passiflora caerulea L., por sua vez consta das farmacopéias do Paraguai e da Indonésia (49).

A Farmacopéia Brasileira à diferença das anteriores, em suas tres edições, elegeu como oficial a espécie passiflora alata Dryander, indicando a foTha como parte usada $(50,17,18)$. Esta espécie tem sido com frequēncia substituĩda por outras, entre as quais se destaca Passiflora edulis sims. A rigor, tal procedimento de"? ser evitado, pois constitui fraude.

A substituição indevida de drogas vegetais ao lado da falta de padronização de seus extratos tem representado obstáculos à eficācia da fitoterapia em nosso pats. 
Tem por objetivo o presente traba1 ho fornecer subsidios para o conhecimento da droga denomi nada maracujá e de seus extratos, efetuando:-

a) a morfodiagnose comparativa das espécies:

Passiflora alata Dryander

Passiflora edulis sims.

Passiflora quadrangularis L.

Passiflora incarnata L.

b) diferenciação e caracterização cromatogrāfica dos extratos fluídos obtidos a partir destes vegetais

c) estudo do extrato de Passiflora alata Dryand.abor dando os seguintes aspectos:

- anālise quantitativa das frações alcaloídica e flavonoídica

- verificação da atividade depressora sobre o sis tema nervoso central

- determinação da toxicidade aguda. 


\title{
2.1 - ASPECTOS BOTANNICOS
}

\subsection{1 - Generalidades}

\begin{abstract}
A famflia Passifloraceae, criada por Jussieu no ano de 1805 (1), consiste de aproximada mente 650 espēcies e de 16 genneros distribuidos nas regiões tropicais e subtropicais do globo (13). Suas espécies ocor rem em maior número na Amërica e Africa Tropical. Segundo Sacco (58) quatro gêneros de Passifloraceae ocorrem no Bra sil, a saber: Passiflora L., Tetrastylis B. Rodr., Dilkea Mast. e Mitostemma Mast. Na famiilia predomina o gênero Passiflora L. com aproximadamente 400 espécies. Este gêne ro é originārio da região tropical da América do Sul com seu maior centro de distribuição geogrāfica no Brasil centro norte. Apenas poucas espēcies ocorrem na Asia, Austrā lia, Africa e Estados Unidos, ocorrendo somente uma em Madagascar (59).
\end{abstract}

O Brasil é bem representado no que diz respeito ao género Passiflora L.. De acordo com Master ocorrem no Brasil pelo menos 79 espécies de Passiflora L.. An gely ( 1 ) cita a presença de 24 espécies de Passiflora L. pa ra o Estado de São Paulo ao passo que Sacco (58) menciona a presença de 28 espécies deste gênero na região compreendida entre Santa Catarina e Rio Grande do Sul. 
2.1.2 - Posição Sistemática

Segundo o Sistema de classificação de Engler (16), o gênero em estudo assim se posiciona:

$$
\begin{aligned}
& \text { 17- Divisão: Angiospermae Brongniart } \\
& \text { 1a Classe: Dicotyledoneae } D C \text {. } \\
& \text { 1a Sub-Classe: Archichlamydeae Engler } \\
& \text { 34a Ordem : Violales Melchior } \\
& \text { 1a Sub-Ordem: Flacourtiineae Engler } \\
& \text { 8a Familia: Passifloraceae Jussieu } \\
& \text { Gênero: Passiflora L. }
\end{aligned}
$$

Segundo o sistema filogenētico de Cronquist (13) Passiflora L. é gēnero com a seguinte posição sistemātica:

$$
\begin{aligned}
& \text { Divisão: Magnoliophyta } \\
& \text { Classe : Magnoliopsida } \\
& \text { Sub-Classe IV: Dilleniidae } \\
& \text { Ordem 6: Violales } \\
& \text { Famīia: Passifloraceae }
\end{aligned}
$$

\subsection{3 - O Gênero Passiflora L.}

o gênero Passiflora L., segundo Leitão Filho e Aranha (30) compõe-se de plantas herbáceas ou sublenhosas, trepadeiras ou muito raramente eretas. As folhas são alternas, simples, inteiras lobadas ou digitadas, com estipulas persistentes, no geral bem desenvolvidas e foliáceas. Com frequēncia, na base da folha ou sobre o pe- 
cĩolo, surgem nectārios alongados ou esféricos. Também è comum a ocorrência de gavinhas. As flores são grandes, muj to vistosas, solitārias, aos pares, em rácemos ou cimeiras, na base protegidas por brácteas foliāceas, hermafroditas. o cālice é tubuloso, de forma variāvel, herbáceo ou subcarnoso, com 5 sépalas oblongas, membranāceas ou coriāceas, comumente providas, no āpice da face externa, de um apēndice agudo. A corola possui 5 pétalas (muito raramente com pētalas ausentes) de tamanho, às vezes, pouco menor que o das sépalas. Apresentam-se livres ou levemente concrescidas na base, inseridas sobre o bordo do tubo calicinal. A corona, formada por 1-5 verticilos, e inserida na base do tú bo calicinal, é composta por filamentos ou efigurações diversas, de cores vivas e atraentes, desempenhando importan te papel para atração de insetos polinizadores. 0 androgi nōforo é colunar e bem desenvolvido. 0 androceu é formado por 5 estames, com filetes livres e inseridos abaixo do ovārio; anteras dorsifixas, versāteis. 0 ovārio está loca lizado sobre ginöforo globoso e é unilocular, e multiovula do com placentação parietal. Os estiletes em nümero de 3 , são livres ou conatos na base, sendo providos de estigmas capitados. O fruto é do tipo baga, possuíndo forma variável e as sementes possuem arilo e endosperma carnoso.

Killip (28) divide o gēnero Passiflora L. em 22 sub-gēneros. Granadilla, o décimo oitavo deles,ē constituĩdo de 15 sēries. A sërie 1 - Quadrangularis inclui as espécies: Passiflora quadrangularis L. e Passiflora alata Dryand. e ’a sērie 9 - Incarnatae pertencem as espé- 
cies Passiflora incarnata L. e passiflora edulis sims, espē cies estas, alvo do nosso estudo.

- Diagnose das espëcies

- Passiflora alata Dryand.

Bot.Mag. 1: p1. 66. 1781 .

Sinonimia(28): - Passiflora mauritiana Du Pet. Thouars.

Ann.Mus.Hist.Nat. 6: 457.pl. 65. 1805.

Passiflora maliformis Vell.

F1.Flum. 9: p1. 73. 1827. Not P.maliformis L.

Passiflora tetradena Vand.

in DC. Prodr. 3:331. 1828. Not P.tetraden Ve11.

Passiflora latifolia DC.

Prodr. 3:328. 1828.

Passiflora pyriformis DC.

Prodr. 3:331. 1828 .

Passiflora brasiliana Desf.

Cat.P1.Hort.Reg. Paris ed. 3.411. 1829.

Passiflora mascarensis Pres 1 .

Bot.Bemerk. 72. 1844.

Passiflora oviformis M. Roemer.

Fam.Nat.Syn.2:167. 1846 .

Passiflora alata var. brasiliana Mast.

Trans.Linn.Soc. 27:635. 1871; in Mart.F1.

Bras. 13, pt. 1:597. 1872.

Passiflora alata var. latifolia Mast.

Trans.Linn.Soc. 27:635. 1871; in Mart.F7.

Bras. 13, pt. 1:597. 1872 . 
Passiflora alata var. mauritiana Mast.

Trans.Linn.Soc. 27:635. 1871; in Mart.F1.Bras. 13, pt. $1: 597.1872$.

Passiflora sarcosepala Barb. Rodr.

Contr.Jard.Bot. Rio de Janeiro 4:93. pl 15. 1907.

Provavelmente origināria do Brasil,

segundo Sacco (58), é planta inteiramente glabra, de caule firme, tetraangulado, sendo os āngulos alados. As folhas são simples, inteiras, ovadas ou ovado-ablongas, membranäceas, peninervadas, acuminadas no āpice, arredondadas, sub cordadas ou subcuneadas na base, de margem lisa ou finamen te denticulada, com 6,0 a $21,5 \mathrm{~cm}$ de comprimento e 5,0 a $13,5 \mathrm{~cm}$ de largura; os pecíolos medem 2,0 a $6,0 \mathrm{~cm}$ de compr $\underline{i}$ mento e são superiormente canaliculados com 2 a 4 glāndulas sēsseis, orbiculares. As estîpulas são persistentes, 1 ineares ou 1 inear-1anceoladas a ovado-1anceoladas, de margem 1 isa ou serrilhada, com 1,0 a $2,0 \mathrm{~cm}$ de comprimento e 0,3 a $1,0 \mathrm{~cm}$ de 1 argura. As flores medem 10,0 a $12,0 \mathrm{~cm}$ de diāmetro e são odorîferas, axilares, em geral isoladas, às vezes em inflorescências pseudoracemosas. os pedūnculos apresentam-se trigonos, com 1,2 a $2,5 \mathrm{~cm}$ de comprimento e as brācteas são foliāceas, 1 ivres, inseridas junto à base da flor, ovadas, agudas, sub-cordadas na base, de margem lisa ou serrilhada, com atē $3,0 \mathrm{~cm}$ de comprimento e $2,2 \mathrm{~cm}$ de largura. O tubo calicinal possui forma curto-campanulada com cerca de $1,2 \mathrm{~cm}$ de diāmetro e sépalas carnosas, oblon gas, obtusas, aristadas, pouco abaixo do āpice. Externamen te são verdes com as porções que permanecem encobertas bran 
co-arroxeadas e a face interna profundamente carmesim, medindo cerca de $3,5 \mathrm{~cm}$ de comprimento e $1,7 \mathrm{~cm}$ de 1 argura. As pētalas são oblongas, obtusas, externamente, brancas ou bran co arroxeadas e internamente, carmesins, com 3,8 a $5,0 \mathrm{~cm}$ de comprimento e 1,5 a $2,0 \mathrm{~cm}$ de 1 argura. A coroa possui quatro sēries, as duas externas filamentosas, com os filamentos subulados, bandeados de branco e vinoso na base e bran co e roxo do centro para o āpice, o qual se apresenta esbranquiçado. Medem 2,5 a 4,0 cm de comprimento e as duas sēries internas são constituĩdas por processos tuberculiformes de 0,2 a $0,3 \mathrm{~cm}$ de comprimento. 0 opérculo é membra noso, horizontal, incurvo e denticulado na margem, branco, manchado de vinoso superiormente. O 1 îmen possui forma anu lar, è carnoso, de base vinosa; androginóforo esverdeado, com dois processos anulares prōximo ao meio; ovārio oblongo ou obovado, glabro, obscuramente sulcado longitudinalmente. Fruto é obovōide ou piriforme, glabro, com 8,0 a $10,0 \mathrm{~cm}$ de comprimento e 4,0 a $6,0 \mathrm{~cm}$ de largura, amare10 quando maduro. As sementes são cordado-oblongas, com 0,8 $\mathrm{cm}$ de comprimento e $0,55 \mathrm{~cm}$ de 1 argura, de testa lustrosa e reticulada.

- Passiflora edulis Sims.

Bot.Mag. 45:p1. 1989. 1818.

Sinonimia (28):-Passiflora gratissima St. Hil.

Mém.Mus.Hist.Nat. 5:350.p1. 25, f.23-26.

1819 .

Passiflora pallidiflora Bert.

Syl1.P1.Hort.Bonnon. 6. 1827. 
Passiflora diaden Vel1.

Fl.Flumin. 9: p1.90. 1827.

Passiflora verrucifera Lindl.

Bot.Reg. 26: p1. 52. 1840 .

Passiflora Middletoniana Paxton.

Bot.Mag. 9: p1. 51. 1842.

Passiflora rigidula Jacq.

Eclog. P1. 2: p1. 124: 1844 .

Passiflora rubricaulis Jacq.

Ecog1. P1. 2: p1. 169. 1844 .

Passiflora pomifera M. Roemer.

Fam.Nat.Syn. 2: 179. 1846.

Passiflora edul is var. verrucifera Mast.

Trans.Linn.Soc. 27: 637. 1871; in Mart. F1.

Bras. 13, pt. 1:610. 1872 .

Passiflora edulis var. pomifera Mast.

Trans.Linn.Soc. 27: 637. 1871; in Mart. Fl.

Bras. 13, pt. 1:610. 1872 .

Passiflora edulis var. rubricaulis Mast.

Trans.Linn.Soc. 27: 637. 1871; in Mart. Fl.

Bras. 13, pt. 1:610.1872.

Passiflora picroderma Barb. Rodr.

P1.Nov.Jard.Bot. Rio de Janeiro 1:1. p1.1. 1891 .

Passiflora iodocarpa Barb. Rodr.

P1.Nov.Jard.Bot. Rio de Janeiro 1:3. p1.2. 1891 . 
Passiflora vernicosa Barb. Rodr.

Contr.jard.Bot. Rio de Janeiro 3: 62. p1.9A. 1902.

De acordo com Sacco (58) é uma liana em geral inteiramente glabra à exceção do ovārio, raro inteiramente pilosa. As folhas são simples, profundamente trilobadas (as jovens ocasionalmente inteiras ou bilobadas e ovadas), arredondadas, cordadas, cuneadas ou subtruncadas na base, glandular serradas, subcoriáceas, lustrosas na fase adaxial, trinervadas, com 4,5 a $12,0 \mathrm{~cm}$ de comprimento na nervura mediana, 4,0 a $11,0 \mathrm{~cm}$ nas nervuras laterais e 5,5 a $15,0 \mathrm{~cm}$ entre os äpices dos lobos laterajs. Os lobos são eliticos ou ovado-eliticos, agudos ou acuminados, rara mente subobtusos e os sinus agudos ou subobtusos; os pecĩolos medem até $6,0 \mathrm{~cm}$ de comprimento, são biglandulares, ge ralmente no āpice, bem junto ao 1 imbo e as glāndulas são sēsseis ou curto-estipitadas. As estípulas são linear-subuladas, com cerca de $1,0 \mathrm{~cm}$ de comprimento.

As flores são axilares, isoladas. Me dem até $7,0 \mathrm{~cm}$ de diāmetro e possuem pedúnculos firmes de atē $6,0 \mathrm{~cm}$ de comprimento, articuladas na inserção das brāc teas foliāceas. Estas são ovadas, obtusas ou agudas, cuneadas ou subcordadas na base, serradas, pectinadas ou qua se 1 aceradas, às vezes com glāndulas na margem e medem 1,2 a 2,5cm de comprimento e 0,7 a $2,0 \mathrm{~cm}$ de 1 argura. As sēpalas são oblongas, com 3,0 a $3,5 \mathrm{~cm}$ de comprimento e cerca de $1,0 \mathrm{~cm}$ de 1 argura, aristadas, a arista com cerca de 1,0 cm, glandulosas na margem, externamente verdes e internamen- 
te brancas. As pétalas são subiguais às sépalas, obtusas e brancas. A coroa é formada de 4 ou 5 sëries filamentosas, das quais as duas séries externas são constituĩdas por filamentos filiformes ou estreitamente 1 iguliformes, medin do atē $2,5 \mathrm{~cm}$ de comprimento, encrespados para os àpices, brancos, purpureo na base. As sēries sucedentes possuemfi lamentos linear-falcados, de 0,2 a $0,3 \mathrm{~cm}$ de comprimento ou reduzidos a pequenos processos dentiformes. A parede interna do tubo calicinal è lisa ou finamente tuberculada. 0 opérculo é membranoso, incurvo, inteiro ou curto-fimbriado; 1 ímen cupuliforme, inteiro ou crenulado. o androginóforo mede cerca de $1,0 \mathrm{~cm}$ de comprimento e o ovārio é ovōide ou globloso, em geral seríceo-tomentoso, raro glabro. 0 fruto $\bar{e}$ ovōide ou globoso, $\operatorname{com} 4,0$ a $5,0 \mathrm{~cm}$ de diāmetro, amare 10, amarelo-esverdeado ou purpuráceo. As sementes são ovais com 0,5 a $0,6 \mathrm{~cm}$ de comprimento e 0,3 a $0,4 \mathrm{~cm}$ de largura, providas de testa finamente reticulada.

\section{- Passiflora quadrangularis $L$.}

Syst.ed. 10. 1248. 1759.

Sinonimia (28):-Granadilla quadrangularis Medic,

Malyenfam. 97. 1787.

Passiflora quadrangularis var.sulcata Jacq. Stirp.Amer. 232. 1763.

Passiflora tetragona M. Roemer.

Fam.Nat.Syn. 2: 165. 1846.

Passiflora macrocarpa Mast.

Gard.Chron. 1869: 1012. 1869. 
De acordo com Killip (28) è planta inteiramente glabra. O caule è vigoroso, com 4 àngulos cons picuosamente alados. As estípulas são ovadas ou oval-1anceoladas de 2,0 a $3,5 \mathrm{~cm}$ de comprimento por 1,0 a 2,0 cm de 1 argura, agudas no āpice, estreitas na base, inteiras ou levemente serrilhadas, fino-membranaceas. Os peciolos medem de 2,0 a $5,0 \mathrm{~cm}$ de comprimento, fortemente canaliculados no lado supe rior. Apresentam 6 glāndulas, distribuidas aos pares, quase sésseis. As folhas são inteiras, largamente ovaladas ou ova1-oblongas de 10,0 a $20,0 \mathrm{~cm}$ de comprimento, 8,0 a $15,0 \mathrm{~cm}$ de largura abruptamente acuminadas, arredondadas, subtruncadas, levemente cordadas, de margem 1 isa. Apresentam-se peniner vadas, e a nervura mediana é proeminente, fortemente eleva da na face inferior, com 10 a 12 nervuras laterais tambēm salientes. Os pedúnculos medem 1,5 a $3,0 \mathrm{~cm}$ de comprimento, são triangulares. Brācteas são cordato-ovadas, medem 3,0 a $5,5 \mathrm{~cm}$ de comprimento, 1,5 a $4,0 \mathrm{~cm}$ de 1 argura, agudas ou sub-agudas, inteiras ou serrilhadas perto da base, finamembranāceas. As flores, de ate $12,0 \mathrm{~cm}$ de 1 argura, possuem tu bo calicinal campanulado; sépalas ovadas ou ovado-oblongas medindo 3,0 a $4,0 \mathrm{~cm}$ de comprimento por 1,5 a $2,5 \mathrm{~cm}$ de 1 argura, são côncovas, cuculadas no āpice, corniculadas, esverdeadas ou vermelho esverdeado exteriormente, branca, viole ta ou rósea por dentro. As pétalas variam de oblongo-ovadas a oblongo-lanceoladas; medem 3,0 a $4,5 \mathrm{~cm}$ de comprimento, 1,0 a $2,0 \mathrm{~cm}$ de largura, são obtusas, 1 isas, brancas e mais profundamente, de cor rósea. A corona possui 5 file $i$ ras, das quais as 2 superiores são filamentosas, aproximadamente do mesmo tamanho (filamentos de até $6,0 \mathrm{~cm}$ de com- 
primento, de tamanho igual ou um pouco maior que o das sépalas, disposição radiada, com faixas de coloração pūrpura avermelhada e branca na base, azul no meio, densamente me $\underline{s}$ clada de azul rosada na metade superior), a terceira filej ra tubercular (filamentos clavados de cerca de 2,0mm de comprimento, fortemente roxo avermelhados), a quarta fileira filamentosa ( $f i l a m e n t o s ~ 1,0$ a $1,5 \mathrm{~mm}$ de comprimento, com fa xas de cor pūrpura avermelhada e branca), e a fileira mais interna membranācea de 3,0 a $7,0 \mathrm{~cm}$ de comprimento, fendido em segmentos de diferentes tamanhos, levemente inclinados para a parte interna. O opérculo è membranāceo de 4,0 a $6,0 \mathrm{~cm}$ de comprimento; inclinado para dentro, denticulado, branco, pūrpuro avermelhado na margem. O límen ē anelar, carnoso; ginōforo firme, alargado no terço inferior pela presença de 2 processos anelares (troclea). 0 ovārio possui forma ovóide e o fruto, oblongo-ovóide, mede de 20,0 a $30,0 \mathrm{~cm}$ de comprimento por 12,0 a $15,0 \mathrm{~cm}$ de 1 argura, arredon dado ou com 3 arestas dispostas longitudinalmente. As sementes marcadamente obcordadas ou suborbiculares medem de 7,0 a $10,0 \mathrm{~mm}$ de comprimento por 5,0 a $8,5 \mathrm{~mm}$ de 1 argura, são completamente 1 isas, reticuladas no centro de cada face, ra dialmente estriadas na margem.

\section{- Passiflora incarnata $L$. \\ Sp.P1.959. 1753.}

Sinonimia (28):- Granadilla incarnata Medic.

Malvenfam.96. 1787 .

Passiflora Kerii Spreng.

Syst.Veg. 3: 39. 1826. 
Passiflora incarnata var. integriloba $D C$

Prodr. 3: 329.1828.

Passiflora edulis var. Kerii Mast.

Trans.Linn.Soc. 27: 637. 1871; in Mart. F1. Bras. 13, pt. 1:610. 1872 .

Caracteriza-se conforme killip (28) como planta glabra ou finamente pilosa, provida de caule cilindrico, anguloso nas partes mais jovens, apresenta estípulas setáceas de 2,0 a $3,0 \mathrm{~cm}$ de comprimento, facilmen te decỉduas. Os pecíolos medem atē $8,0 \mathrm{~cm}$ de comprimento são biglandulares no āpice e as glāndulas são suborbiculares e sésseis. As folhas medem de 6,0 a $15,0 \mathrm{~cm}$ ao 10 ngo da nervura mediana e 5,0 a $12,0 \mathrm{~cm}$ ao 10 ngo das nervuras lateraise 7,0 a $15,0 \mathrm{~cm}$ entre os ápices dos lobos laterais; tri lobadas a partir de $3 / 4$ a $4 / 5$ do seu comprimento (10bos ova do-lanceolados ou oblongo-lanceolados, de 2,0 a $5,0 \mathrm{~cm}$ de comprimento, agudos ou acuminados, o lobo central estreito na base, raramente os lobos laterais divididos), cordulados, finamente serrados, trinervados, membranāceos, verde escuros na face superior, glaucescente na inferior. Os pedūncu los medem até $10 \mathrm{~cm}$ de comprimento e são firmes. As brācteas são espatuladas ou oblongas, medindo de 4,0 a $7,0 \mathrm{~mm}$ de comprimento por 2,5 a 4,0mm de largura, são obtusas ou agu das, minusculamente glandular-serrilhadas perto do ápice, conspicuamente biglandulares na base, situadas cerca de $5,0 \mathrm{~mm}$ abaixo da flor. As flores medem até $7,0 \mathrm{~cm}$ de $1 \mathrm{argu}-$ ra e o tubo calicinal è curtamente campanutado. As sépalas 
são lanceolado-oblongas, de 2,0 a $3,0 \mathrm{~cm}$ de comprimento por 0,8 a $1,0 \mathrm{~cm}$ de largura, brancas ou de coloração levemente lịās, obtusas, cuculadas no āpice, levemente carenadas, com a carena terminando em prolongamento de 2,0 a $3,0 \mathrm{~cm}$ de com primento. As pétalas são de tamanho menor ou igual ao das sépalas, obtusas, de coloração branca ou lilās claro. A co rona em várias fileiras de cor roxa ou rosa, raramente é só branca, sendo as 2 fileiras superiores filiformes, com 1,5 a $2,0 \mathrm{~cm}$ de comprimento, crispadas no āpice, 1 igeiramen te alargadas na base e radiadas. As trés fileiras subsequentes são capilariformes, com cerca de $2,0 \mathrm{~mm}$ de comprimento, radiadas ou suberetas. As fileiras mais internas são membranāceas na base, filamentosas, com filamentos de aproximadamente $4,0 \mathrm{~mm}$ de comprimento, capitados. 0 opércu 10 é membranāceo mede cerca de $2,0 \mathrm{~mm}$ de comprimento, é recurvado para o interior e fimbriado. 0 anel nectarífero é levemente protuberante, situando-se medianamente entre o opérculo e o ginóforo. O 1 ìmen é cupuliforme, intimamente 1 igado à base do ginōforo, crenulado. o ovārio é ovōide, amarronzado ou velutino-tomentoso esbranquiçado e o fruto é ovóide ou subgloboso, medindo até $5,0 \mathrm{~cm}$ de comprimento. As sementes são obovadas ou quase obcordadas de 4,0 a 5,0 $\mathrm{mm}$ de comprimento por 3,0 a $4,0 \mathrm{~mm}$ de largura, truncadas no àpice e reticuladas. 
2.1.4 - Caracteristicas Anatōmicas de Passifloraceae Jussieu

As follhas das espécies pertencentes

à familita Passifloraceae geralmente apresentam, segundo Met calfe (43), estrutura dorsiventral. Mesofilo heterogéneo simëtrico pode ocorrer com menor frequēncia em espécie dos gēneros Adenia Forsk, Paropsia Nor ex Thouar, Passiflora L. e Tryphostemma Harv. Pêlos tectores simples, por vezes em forma de gancho, ou unisseriados aparecem em vārias espécies de Passiflora L.. Apresentam, ocasionalmente, pêlos gländulares verrucosos com pedicelos multiseriados, äs vezes, vascularizados e a glāndula esférica, bem como projeções cuticulares da epiderme. A epiderme apresenta-se par te ou completamente bisseriada, e muitas vezes, papilosa na face inferior onde se confinam os estomatos anomociticos. Na parte central do mesōfilo aparecem esclereïdeos em poucas espécies do gênero Passiflora L.. Fibras de esclerénquima acompanham em alguns casos as nervuras presentes no mesofilo. Elementos secretores são comuns na região parenquimática, incluindo frequentemente cēlulas e re ceptáculos contendo substāncias tānicas. Não é mencionada a presença de hipoderme no gēnero Passiflora L.. Cristais de oxalato de cālcio isolados ou agrupados podem ser encon trados neste gēnero.

Os caules das espēcies do gēnero Passiflora $L$. segundo Metcalfe (43) podem apresentar-se a gulosos alados ou cilindricos. O felógeno aparece quase sempre logo abaixo da epiderme e em alguns casos forma-se 
a partir deste tecido. O periciclo é descontinuo e fibroso. Pequenos grupos de fibras podem ser observadas na região floemática. 0 xilema pode ter disposição cilîndrica contînua, mas frequentemente estão presentes raios medulares.

As perfurações dos vasos são simples. Elementos secretores incluem sacos taniferos com grande lümen, muitas vezes, com finas paredes, de forma alon gada, localizados no córtex ou medula de poucas espécies do gênero Passiflora L.. Cristais prismáticos também estão presentes nos tecidos caulinares ocorrendo isoladamente ou agrupados.

\section{2 - ASPECTOS HISTORICOS}

Etimologicamente Passiflora significa flor da paixão. Este termo è formado de duas palavras latinas; de passio, passiones que significa paixão e de flos, floris que significa flor.

Os escritores do sēculo XVI atribui ram às flores dos maracujās um significado mîstico. Assim, interpretaram suas diferentes partes como represantando os símbolos da Paixão de Cristo. Por esta razão estes vegetais são conhecidos na Europa e América do Norte como flor da paixão (59).

o termo maracujā, amplamente utilizado no Brasil para os vegetais em estudo é de origem tupi 
guarani. Admite-se que este termo provenha de muruku'ia cujo significado é comida preparada em cuia numa alusão aos frutos èdulos do vegetal (26).

E atribuida a Monardes, médico espa nhol, a primeira menção a espécie deste grupo, referindo-se em 1569 a uma planta encontrada por ele no Peru. Este facultativo impressionou-se pelas propriedades curativas atri buịdas à granadilla nome atribuído naquela região a $\underline{P}$. incarnata L. (26). $110 \mathrm{EHA}$

Prosadores, poetas, e artistas citam há muito o maracujā, quer por suas belas flores, quer pelo sabor acre-doce agradabilissimo de seus frutos.

Pelas suas propriedades medicinais Cardim em 1584 e Soares em 1590 (14) referem-se aos maracu jās. Mencionam remédio feito com as folhas da planta, que espremidas, eram empregadas no tratamento das boubas e chagas veltias.

Caminhoà ( 9 ) relata o uso na medicina popular no Brasil, de vārias espécies de Passiflora L. Segundo este autor, as folhas eram empregadas na forma de decocto como medicação antigotosa. O suco era utilizado como frebĩfugo e as raīzes como vermīfugas. A espécie $\underline{P}$. quadrangularis L. é citada por ele como ocasionadora de so no, passando as raizes desta planta, como narcōticas e ve nenosas.

Pio Correa (11) de maneira semelha $\underline{n}$ te cita as folhas de maracujā como usadas no combate às fe bres intermitentes, inflamações cutāneas e erisipela. São 
ainda, consideradas como diaforēticas, anti-histēricas e anti-helminticas. Este autor menciona a presença nestes vegetais de uma substância semelhante à morfina denominada de passiflorina,indicada como calmante.

A introdução do uso do maracujā pelas suas propriedades sedativas ocorreu na Europa no sécu10 XVII. Nesta ocasião, o uso de $\underline{P}$.incarnata L., $\underline{P}$. caerulea L. e P. lutea L. como calmante foi iniciado.

O estudo sistemático das passifloras, apesar da diversidade inicial de suas indicações, convergiu para a avaliação da atividade sedante. A partir do fim do século passado começạram a aparecer estudos farmaco 1ógicos sobre P.incarnata L.. Em 1867, Phares, nos Estados Unidos, utilizou este vegetal no tratamento de doenças nervosas (3) e em 1904, stapleton obteve bons resultados no tratamento de insōnias e de neurastenia de alcoolatras(29).

\section{3 - ASPECTOS QUIMICOS}

O estudo do gênero Passiflora L., con siderado sobre o ponto de vista químico, experimentou razoá vel aceleração a partir do início do presente século.

Em 1909, Peckolt verificou a presen ça de dois alcalóides em suas pesquisas com vārias espécies de Passiflora L.. Às substāncias isoladas deu o nome de: passiflorina e maracujina (12). 
Fellows e Smith em 1938, (19) isola

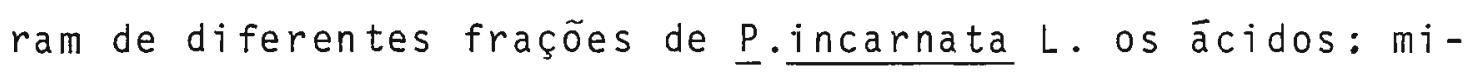
rístico, palmítico, oleíco, linoleícoelinolēnico; sitoste rol, catecol, àcido gālico e glicose.

$$
\text { - Neu, em } 1954 \text { (45) extraiu de } \underline{P} \cdot \underline{i n-}
$$

carnata L. uma substāncia de natureza alcaloídica, tendo como provāvel förmula molecular $\mathrm{C}_{12} \mathrm{H}_{10} \mathrm{~N}_{2}$.. Esta substāncia apresentava intensa fluorescência à 1 uz ultravioleta e pon to de fusão $237-8^{\circ} \mathrm{C}$. Este mesmo autor, no ano de 1956 (46) trabalhando com diversas espécies de Passiflora L. isolou um alcalóide de natureza indólica, o qual constatou ser a harmana.

Lutomsky (34) detectou a presença de cinco alcalóides nos extratos metanólico e aquoso acidi ficado de . incarnata L., encontrando teores de alcalóides totais de $0,090 \%$ no extrato alcoólico e de $0,055 \%$ na solução ácida. A mistura alcalojidica estudada era composta de $39 \%$ de harmol, $27 \%$ de harmana e 22\% de harmina. Em 1959, este mesmo autor (33), estudando a extração de harmana, har mina e harmol em material vegetal, verificou ser o metanol - solvente que melhor se presta para este trabalho.

0 extrato clorofórmico obtido a par tir de $\underline{\text { P.incarnata }}$ L., submetido a fracionamento em coluna cromatográfica de celulose por Lutomsky (34), permitiu o isolamento de harmana, harmina e harmol em forma cristalina ao lado de dois outros alcalóides em forma amorfa.

A cromatografia em camada delgadade extrato de plantas contendo alcalóides harmānicos serviu a 
Lutomsky e colaboradores na montagem de técnica que permitiu a avaliação qualitativa(34) e quantitativa (36) dessas substâncias.

Bennati (4) desenvolveu técnicas de identificação de alcalóides harmānicos em extratos de $\underline{\text { P.incarnata }}$ L.. Este autor utilizou cromatografia em cama da delgada (5) e cromatografia em fase gasosa. Efetuou ainda determinação quantitativa de harmana e harmina por densito metria no ultravioleta diretamente de cromatograma em cama da delgada.

Trabalhando com algumas espécies de

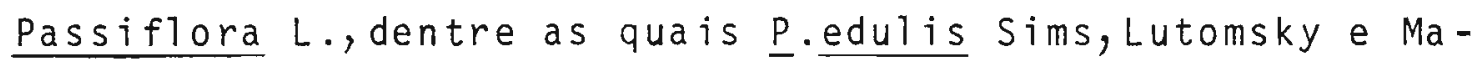
lek (37) compararam o teor de alcalóides harmānicos nos di ferentes ōrgãos dos vegetais. Verificaram que o maior teor destes compostos ocorre nas folhas daquela espécie.

Em pesquisa posterior, estes mesmos autores verificaram a presença de alcalóides em todas as partes daquele vegetal, exceto nas raizes (39). Eles determinaram ainda no ano de 1975, por cromatografia em papel seguida de densitometria, o conteúdo alcalöidico, o qual foi expresso em harmana. Encontraram nas folhas teor de $0,70 \mathrm{mg} \%$ e no cau1e $0,17 \mathrm{mg} \%$. Neste traba 1 ho empregaram extra

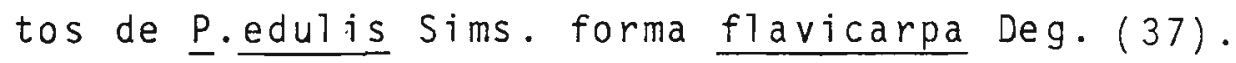

Em 1960,Lutomski e Wrocinski (41) avaliaram química e farmacologicamente preparações de $\underline{P}$. incarnata L.. Encontraram 0,072\% de alcalóides totais e $0,057 \%$ se considerados em conjunto: harmana, harmina ehar mol. Isolaram ainda do vegetal uma fração flavonoídica. 
Os autores alertaram sobre a importäncia da presença do com plexo alcalóide-flavonóide na obtenção de melhor atividade farmacológica. Verificaram que o extrato etanōiico da plan ta contēm este complexo.

Theodossiou em 1965 (63), confirmou a presença de flavonóide em preparações galênicas de $\underline{\text { P.incarnata }} L$. e de $\underline{\text { P.caerulea }} L$.. Identificou tambëm nes tes extratos, pelo método de Neu, alguns alcalöides harmānicos.

Schilcher (60) desenvolveu mētodos de avaliação qualitativa e quantitativa de drogas do comērcio de espécies de Passiflora L.. Este autor preocupouse com a fração flavonoidica. Detectou a presença de seis flavonóides por cromatografia em camada delgada usando como camada celulose microcristalina. Desenvolveu ainda métodos de avaliação semiquantitativa e quantitativa.

Em 1968, foram isolados de P.incarnata L. por Schilcher (61), os flavonōides vitexina, isovitexina e saponarina. Ainda neste ano, Lutomski e Adamska

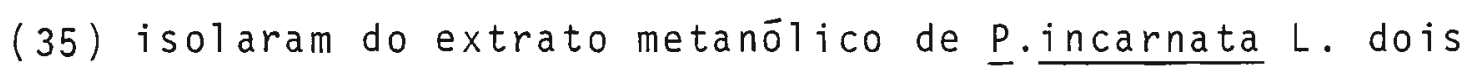
compostos de natureza flavonoídica, um deles identificado como vitexina.

Glotzbach e Rimpler (24) analisaram comparativamente os extratos de $\underline{P}$. incarnata L., $\underline{\text { Pquadran }}$ gularis L. e P.pulchella H.B.K. com relação à presença de flavonóides. Estes autores utilizaram cromatografia em pa pel e cromatografia em camada delgada, empregando neste ca so sîlica gel como camada e acetato de etila: ācido fórmi- 
co: āgua, como sistema solvente.

Gavasheli (21) estudando diversos estágios de desenvolvimento de $\underline{P}$. incarnata L. quanto aos teores de compostos flavonoídicos, verificou que eles variam nas folhas de 0,15 a $0,22 \%$, e nas raízes de 0,13 a $0,35 \%$ o teor de flavonóides nas folhas é maior no período de flo ração do vegetal. Nas raĩzes ele é mais alto antes da flo ração, sendo menor durante a frutificação.

Gavasheli e colaboradores (23) analisaram o extrato metanōlico das folhas de -incarnata L. Através de cromatografia em coluna de poliamida,lograram isolar e identificar os quatro flavonóides seguintes: apigeni na, 1 uteolina, quercetina e campferol.

Halim e colaboradores (25) detectaram em $\underline{P}$.quadrangularis $L$. a presença de quatro antocianinas, nas quais o açücar era a glicose e as geninas, a cianidina, a malvidina, a petulina e a delfinidina.

Nas raizes de $\underline{P}$.incarnata L., Gavasheli (22) e colaboradores encontraram substāncias de natureza cumarinica a saber: umbeliferona e escopoletina.

Em 1974, a partir de espécimes vege tais de P.incarnata L. introduzidos em Cuba, Svanidso e co laboradores (62) encontraram $0,44 \%$ de flavonóides tota is na droga avaliada espectrofotometricamente. 0 teor de alcalóides totais foi determinado segundo o método de Farmaco Fēia Suiça, sendo igual a $0,014 \%$. 
Os extratos metanōlicos de: $\underline{P} \cdot \underline{\text { caer }} \underline{u}$ lea L., $\underline{P}$.edulis sims., $\underline{\text { p.foetida }}$ L., $\underline{\text { foncarnata }}$ L. e $\underline{\text { inc }}$. warmingii Mast., foram analisados por Lohdefink $e$ Kating quanto ao teor alcaloídico. Nestas espécies foi evidencia da a presença somente de harmana, chegando à conclusão que o doseamento de alcalóides totais pelo método titulométrico leva a um resultado aproximadamente vinte vezes maior que o espectrofotométrico (32).

Em 1976, Lohdefink (31) analisou de talhadamente o conteúdo flavonoídico das espécies citadas no trabalho anterior. Foram identificados os compostos vi texina, orientina, isovitexina, isoorientina, saponarina e outros flavonóides genericamente denominados por ele de: $\mathrm{F}_{2}, \mathrm{~F}_{4}, \mathrm{~F}_{5}$ e $\mathrm{F}_{9}$. Os dois primeiros são 8-C-diglicósidos da apigenina e os dois ūltimos, glicósidos do campferol.

Makauskas e colaboradores (42) analisaram o extrato fluỉdo e a tintura obtidas a partir da droga Passiflora (P.incarnata L.). O teor alcaloídico encontrado foi de 0,5mg\% para a tintura e de 0,78mg\% para o extrato fluído.

Quercia et al. (52) isolaram vitexina e isovitexina por cromatografia 1 iquida de alta pressão, de terminando ser $0,23 \%$ o teor de vitexina no extrato mole de Passiflora (P.incarnata L.).

De $\underline{\text { P. alata }}$ Dryand, Ulubelen et al. isolaram recentemente um diglicōsido de natureza flavonoídica: 2-xilosil-vitexina. A proporção encontrada foi de $0,1 \%$ a partir das folhas secas da planta (65). 
Principios ativos isolados de Passiflora spp.

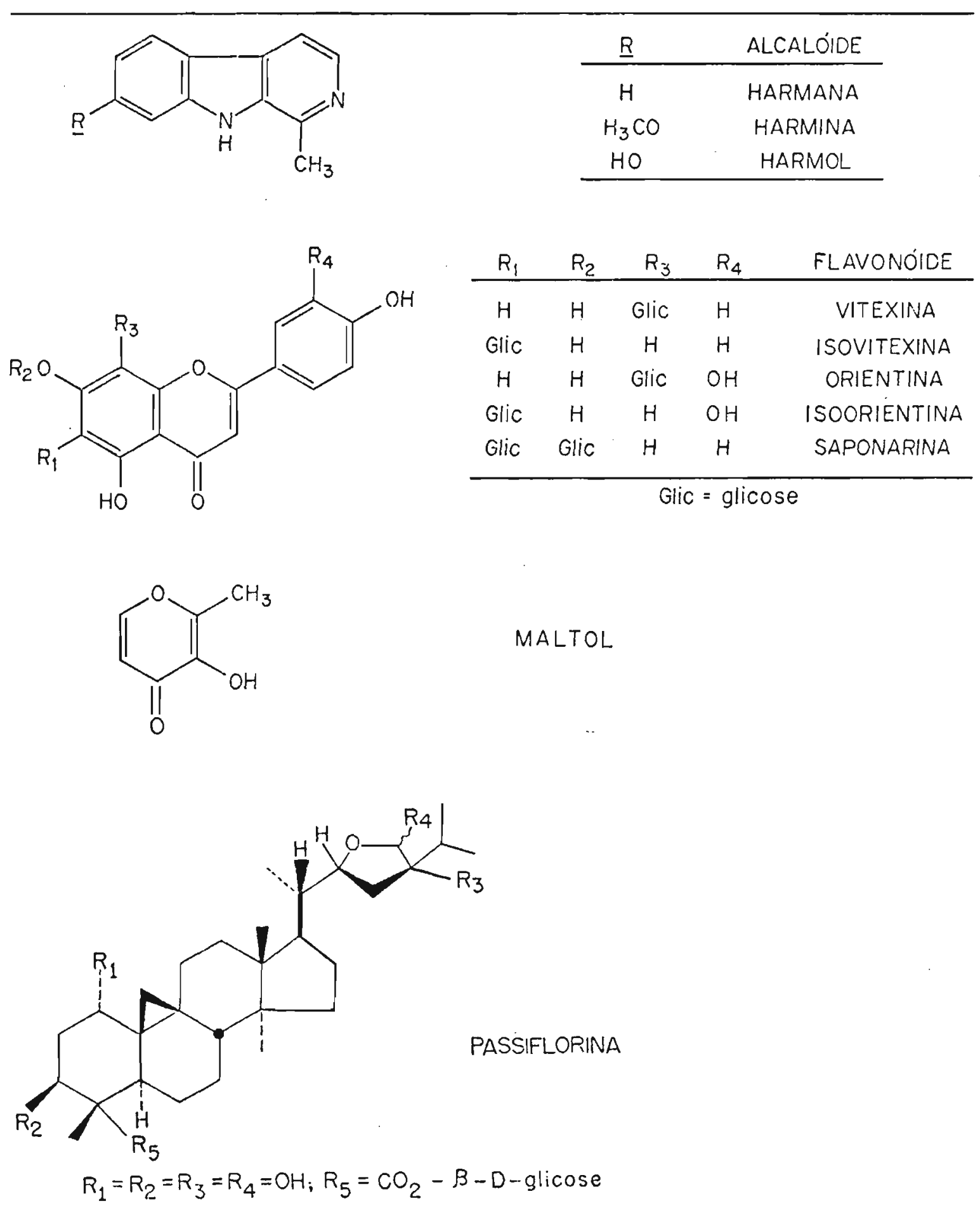




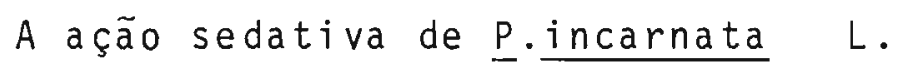
foi pela primeira vez registrada por Phares no ano de 1867 . A confirmação desta atividade foi feita por stapleton que conseguiu melhorar diversos casos de insōnia e de excitação nervosa empregando o extrato deste vegetal e em 1916 foi preconizado por Renon na terapéutica homeopática para - tratamento da agonia de guerra (29).

Segundo De Nito, experiēncias efetuadas em animais de laboratōrio evidenciaram a ação hipotensora de uma das substāncias bāsicas de $\underline{P}$ incarnata L. Se gundo este autor, doses elevadas do extrato fluído provocam uma diminuição da capacidade de animais a reagirem a estímulos externos. Em cães, o extrato fluĩdo determina efeito hipotensor ocasionando vasodilatação periférica (3). Fellows e smith (19) confirmaram este efeito utilizando o extrato aquoso de P.incarnata $L$.

De acordo com Borgatti ( 7$)$, que tra balhou com intestino delgado de coelho, a droga apresenta ação perifērica, causando inicialmente diminuição do tonus, aumento da amplitude e diminuição na frequéncia das contra ções. Este autor verificou ainda que o aumento da concentração do extrato pode causar paralisia intestinal.

Ruggy e Smith (56) isolaram do ex-

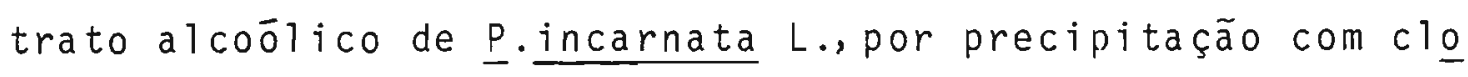
reto de mercūrio, um composto de fórmula empīrica $\mathrm{C}_{10} \mathrm{H}_{22} \mathrm{O}_{8} \mathrm{~N}$. $\mathrm{HgCl}_{2}$. Este composto foi testado farmacologicamente visan 
do verificar sua atividade sobre o sistema cardiovascular de cães e ōrgãos isolados, a saber: intestino de coelho, ūte ro de porca e de coelha. Concluiram que a substāncia apre senta ação parassimpatomimética, causando hipotensão e a contração do músculo 1 iso do intestino. Provavelmente por ação direta sobre tal musculatura (57).

Em 1960, Lutomsky e Wrocinski alertaram para a conveniência de estarem presentes nas prepara ções de Passiflora L. destinadas a ocasionar ação sedante, tanto a fração alcaloídica como a fração flavonoídica. A primeira destas frações teve sua atividade comprovada em camundongos e a segunda, em camundongos e peixes (41).

Os extratos de Passiflora L., segun do Raoul (53) parecem ajudar a inibir a ação do ālcool sobre o sistema nervoso, quando injetados intraperitonialmente.

Aoyagi e colaboradores ( 2 ) partin-

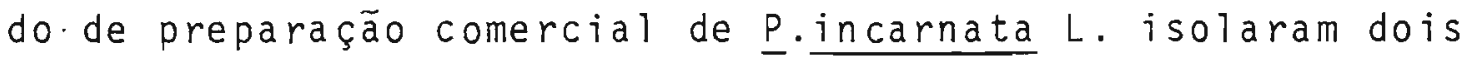
compostos quimicos, a saber: maltol e etilmaltol. Estas duas substāncias foram testadas farmacologicamente quanto à ati tividade depressora do sistema nervoso central, empregando -se ratos nos ensaios. Foi verificada a diminuição da movimentação espontānea dos animais benı como a presença de bradicardia, hipotermia e relaxamento dos mūsculos esquelé ticos. A dose 1 etal $50 \%$ determinada para os compostos estudados, utilizada a via subcutānea, foi de $820 \mathrm{mg} / \mathrm{kg}$ para o ma1tol e de $910 \mathrm{mg} / \mathrm{kg}$ para o etilmaltol. 
Lutomski e colaboradores (40) anal saram os sucos de maracujá feitos com frutos de $\underline{\underline{p}}$. edulis Sims (maracujá vermelho) e de $\underline{P}$.edul is Sims. forma flavicar pa Deg. (maracujá amarelo). Estes autores determinaram os teores de alcalóides e de flavonōides empregando os métodos densitométrico e planiméritrico em cromatografia em ca mada delgada. Nos ensaios farmacológicos, ficou evidencia da a ação depressora sobre o sistema nervoso central, com a diminuição da movimentação espontānea em camundongos,bem como a diminuição do nĩvel de atenção de animais tratados por via oral com os sucos dos frutos de maracujā.

Recentemente, Vale e Leite (66), em ensaios laboratoriais, confirmaram a ação tranquilizante do maracujā-amarel'o $\underline{p}$.edul is Sims. forma flavicarpa Deg. traba lhando com o extrato aquoso de folhas secas à sombra. A preparação que se assemelha ao "chā" consumido popularmente, mostrou baixa toxicidade e atividade depressora do sis tema nervoso central, induzindo o sono em animais de laboratório e reduzindo-1hes a temperatura corporal. 
o material botānico empregado na elaboração do trabalho teve como origem os canteiros de cul turas experimentais do Departamento de Fitotecnia da Facu 1 dade de Ciēncias Agrārias e Veterinārias da UNESP - Campus de Jaboticabal.

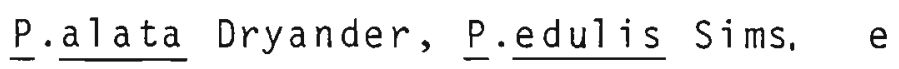
$\underline{P}$-quadrangularis $L$. jā integravam a coleção do Departamento. P.incarnata L. foi introduzida recentemente a partir de sementes provenientes do Departamento de Agricultura dos Estados Unidos (USDA) - Miami - Flörida.

0 material destinado ao estudo morfológico foi dividido em pedaços de tamanho conveniente com os quais foram preparadas exsicatas. 0 material desti nado ao estudo anatōmico foi em parte proveniente de plantas frescas e em parte proveniente de plantas divididas e fixadas em F.A.A. (Formol a 40\%-5ml: ácido acētico glacial$5 \mathrm{ml}$ : $\overline{\mathrm{a}} 1 \mathrm{co0} 1$ a $50 \%-90 \mathrm{~m} 1)$.

3.1 .1 - Cortes Histolögicos

Foram realizados cortes a mão i ivre das seguintes partes dos vegetais: 
- Passiflora alata Dryand.

Folha - corte transversal ao nível do terço médio inferior; cortes paradér micos das epidermes superior e inferior.

Peciolo-cortes aos nîveis superior, médio e inferior, considerados em relação a sua inserção no caute.

Caule - seç̧ões transversais do caule desta cando as regiões: da ala, entre alas e prōximo à gema terminal.

- Passiflora guadrangularis L.

Folha - secção transversal ao nīvel do terço médio inferior; cortes paradér micos das epidermes superior e inferior.

Peciolo-foi cortado transversalmente em di ferentes a1turas: nas regiões: inferior, mediana e superior, considerados a partir de sua inserção no caule.

Caule - cortado transversalmente, destacando-se a região da ala.

- Passiflora edulis Sims.

Folha - cortes transversais da região da nervura principal ao nível do ter- 
ço mēdio inferior; cortes paradērmicos das epidermes superior e inferior.

Pecĩolo-cortado transversalmente nas regiões superior, mediana e inferior, considerando a inserção no caule.

Caule - foram executados cortes transversais.

\section{- Passiflora incarnata $L$.}

Folha - cortes transversais na região da nervura principal na altura do ter ço médio inferior; cortes paradēr micos das epidermes superior e inferior.

Peciolo-cortes executados nas partes inferior, mediana e superior considera das a partir de sua inserção no caule.

Caule - seccionado transversalmente com destaque para a sua região mais ex terna.

Os cortes foram descorados em hipoclorito de sōdio (cāndida diluî̀da em àgua - 1:1), lavados com àgua destilada, corados com solução de hematoxilina de Delafield (18) e montados em mistura de àgua destilada-gli cerina (1:1) entre lâmina e lamīnula. 
Os cortes histológicos foram observados ao microscópio ótico da marca Leitz-Wetzlar e os desenhos das estruturas microscópicas realizados com o auxílio de microprojeção direta a partir do microscópio.

\section{2 - ESTUDO DOS EXTRATOS FLUTDOS}

\subsection{1 - Preparo dos Extratos}

O material botânico destinado à pre paração dos extratos vegetais era constituído de folhas adultas. A secagem foi realizada a sombra e a moagem foi efetuada em moedor Thomas ${ }^{R}$ munido de tamis com $1,0 \mathrm{~mm}$ de abertura das malhas.

Os extratos fluidos foram preparados segundo o processo A da Farmacopéia Brasileira (18)uti lizando como líquido extrator uma mistura de ālcool e água na proporção de $2: 1$.

0 extrato seco de $\underline{\text { P.alata }}$ Dryand. us $\underline{a}$ do para os ensaios farmacológicos foi obtido a partir do extrato fluído da droga, pela evaporação do solvente à tem peratura inferior a $600 \mathrm{C}$.

3.2.2 - Anālise Cromatogrā́fica dos Extratos

\subsubsection{1 - obtenção da fração flavonoídica dos extratos}

Foram tomados individualmente $50 \mathrm{~m} 1$ 
dos extratos fluidos das diversas espécies de maracujā, os quais foram evaporados em banho-maria atē a obtenção de um resíduo de consistência pastosa. o resíduo foi agitado com $40 \mathrm{ml}$ de uma solução aquosa de ācido clorîdrico a $1 \%$. O ex trato àcido sobrenadante foi filtrado por papel de filtro para funil de separação. Esta operação foi repetida por 10 vezes. Os lîquidos àcidos reunidos foram extraídos com 8 porções, de $50 \mathrm{ml}$ cada, de acetato de etila, que foram reu nidas e evaporadas à secura, sob pressão reduzida e temperatura inferior a $600 \mathrm{C}$ (a solução aquosa àcida remanescente desta extração foi utilizada na obtenção da fração alca 1oídica). Ao resĩduo obtido da concentração do acetato de etila foram adicionados $50 m 1$ de àgua fervente e a filtração por Buchner foi feita a quente. Este procedimento foi repetido por 6 vezes e o extrato aquoso reunido foi evaporado à secura sob pressão reduzida, fornecendo um resĩduo amarelado que constituiu a fração flavonoídica. Esta fração foi denominada de F.F.

\subsubsection{2 - Cromatografia em camada delgada das frações flavonoídicas}

Sistema cromatogrāfico $F_{1}$

Adsorvente: sillica gel sobre placa de vidro. Tamanho $20 x$ $20 \mathrm{~cm}$.

Espessura da camada: 0,25mm. Foram utilizadas cromatoplacas Kieselge $160 \mathrm{~F}_{254}$, da firma Merck.

Ativação: por aquecimento a $1100 \mathrm{C}$ por 1 hora. 
Fase móvel: acetato de etila: àcido fōrmico: āgua (90:10:10) Cuba de vidro: tamanho $22 \times 28 \times 10 \mathrm{~cm}$.

Saturação: total

Desenvolvimento: simples, ascendente. Percurso: $15 \mathrm{~cm}$ Visualização: a placa foi observada à 1 uz UV ${ }_{366}$ após reve1 ação com mistura de uma parte de solução aquosa de ácido oxālico a $10 \%$ (p/v) com 3 par tes de solução de ácido börico a $3 \%$ (p/v), seguida de aquecimento a 1200 c por 5 minutos.

Amostra: fração flavonoídica dissolvida em $5 \mathrm{ml}$ de metanol Padrões: soluções de vitexina, isovitexina, orientina em metanol.

\subsubsection{3 - Obtenção da fração alcailoídica dos extratos}

Os 1 íquidos aquosos àcidos remanescentes das extrações das misturas flavonoidicas com acetato de etila, foram alcalinizadas com hidróxido de sódio a $5 \%$ atē $\mathrm{pH}=11$ e extraîdos com 8 porções, de $50 \mathrm{~m} 1$ cada, de clorofórmio. Os extratos cloroförmicos reunidos foram eva porados à secura sob pressão reduzida e o resíduo resultan te, de cotoração branco amarronzado e de natureza amorfa, constituiu a fração alcaloídica (F.A.) do extrato de Passiflora sp. 


\section{2 .2 .4 - Cromatografia em camada delgada das frações alcaloídicas}

Sistema cromatogräfico: $A_{1}$

Adsorvente: silica gel sobre placa de vidro de tamanho $20 x$ $20 \mathrm{~cm}$ e espessura da camada de $0,25 \mathrm{~mm}$. Foram utilizadas cromatoplacas Kieselgel $60 F_{254}$ Merck.

Ativação: por aquecimento a $1100 \mathrm{C}$ por 1 hora

Fase móvel: clorofórmio: metanol $(90: 10)$

Cuba de vidro: tamanho $22 \times 28 \times 10 \mathrm{~cm}$

Saturação: total

Desenvolvimento: simples, ascendente. Percurso de $15 \mathrm{~cm}$ Visualização: observação à 1 uz UV 366

Amostras: frações alcaloídicas diluidas em metanol

Padrões: soluções a $0,1 \%$ em metanol, de harmana e harmina.

3.2.3 - Determinação de Flavonóides em Extrato de

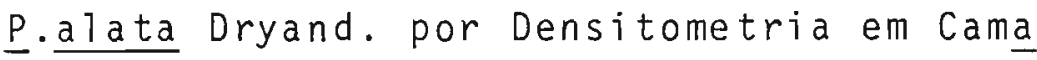
da Delgada.

Utilizando o sistema cromatogräfico do Ftem 3.2.2.2. foram desenvolvidos cromatogramas da fração flavonoídica de $\underline{\text { P.alata }}$ Dryand. obtida em 3.2.2.1. dis solvida em $5 \mathrm{ml}$ de metanol.

A intensificação da fluorescēncia pela exposição aos vapores de amōnia e intensa fluorescēn- 
cia verde amarelada após nebuli zação com solução a lcoólica a $5 \%$ de cloreto de aluminnio, foram reações utilizadas na confirmação da natureza flavonoídica dos compostos evidenciados no cromatograma e que apresentaram Rf compreendidos entre os valores 0,3 e 0,6. A quantificação foi feita pe1 a medida da fluorescēncia destas manchas apōs nebulização com ácido boro-oxālico conforme anteriormente descrito (îtem 3.2.2.2.). Foi feita a comparação com o padrão de orienti na, pelo método densitométrico utilizando o aparelho Photo volt mod. 520 com 1 uz emitida: UV (ondas longas) $366 \mathrm{~nm}$ e filtro de $570 \mathrm{~nm}$. O aparelho foi acoplado a um registrador Sargent welch mod. SRG, sendo as àreas determinadas por triangu 1 a ção.

A curva padrão foi traçada a partir das āreas obtidas com as seguintes quantidades de orientina $0,25,0,50,0,75,1,0$ e $1,25 \mu \mathrm{g}$.

3.2.4 - Determinação de Alcalóides em Extrato de

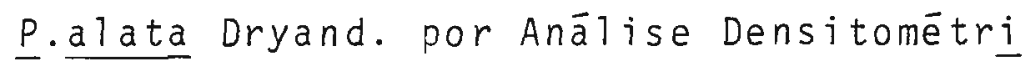
ca em Camada Delgada.

A fração alcaloídica obtida em 3.2.2.3. foi dissolvida em $5 \mathrm{~m} 1$ de metanol e cromatografada segundo o sistema descrito no item 3.2.2.4..

A intensa fluorescéncia azul dos a 1 calóides do grupo harmānico permitiu sua quantificação por densitometria na placa utilizando-se como substancia padrão o alcalóide harmana da firma Fluka. Para tal, foi uti 
lizado o aparelho Photovolt mod. 520 com 1 uz emitida UV 366 e filtro de $445 \mathrm{~nm}$, acoplado ao registrador Sargent-Welch mod. SRG. A curva padräo foi traçada a partir das āreas obtidas por triangulação dos registros dos picos referentes a $0,02,0,04,0,06,0,08$ a $0,10 \mu g$ de harmana.

\section{3 - ENSAIOS FARMACOLOGICOS DE EXTRATO SECO DE P.alata Dryand.}

\subsection{1 - Animais e Tratamento}

Utilizaram-se camundongos machos, de peso compreendido entre 40 e $50 \mathrm{~g}$, fornecidos pelo biotério central do Instituto de Ciēncias Biomédicas da Universidade de São Paulo.

A via de administração utilizada pa ra todos os testes foi a intraperitoneal (i.p.) e todas as substāncias foram aplicadas na forma de solução aquosa.

\subsection{2 - Tempo de Sono Induzido pelo Pentobarbital Sódico.}

Utilizaram-se 30 camundongos, divididos em trés grupos de 10, a saber: grupo controle, trata do com solução de cloreto de sōdio a $0,9 \%$ (salina) e dois grupos tratados com o extrato de P.alata Dryand. $75 \mathrm{mg} / \mathrm{kg} \mathrm{e}$ $150 \mathrm{mg} / \mathrm{kg}$, respectivamente. Após 60 minutos, todos os animais receberam $25 \mathrm{mg} / \mathrm{kg}$ de pentobarbital sódico. 
Os animais foram mantidos em ambien te tranquilo, para que não houvesse interferéncia de estímulo externo no tempo de sono. Assim que os camundongos co meçaram a dormir, foram colocados em decúbito dorsal; a du ração do sono foi determinada medindo-se o intervalo de tem po entre a perda e a recuperação dos reflexos.

\section{3 .3 - Convulsão por Estricnina}

Utilizaram-se 24 aniamis, divididos em quatro grupos de seis a saber: um grupo tratado com salina e outro tratado com $5 \mathrm{mg} / \mathrm{kg}$ de diazepam. Outros dois grupos foram tratados respectivamente com $75 \mathrm{mg} / \mathrm{kg}$ e $150 \mathrm{mg} /$ $\mathrm{kg}$ do extrato de $\underline{\text { Palata }}$ Dryand.. Após 60 minutos, todos animais receberam $3 \mathrm{mg} / \mathrm{kg}$, i.p., de estricnina.

\section{3 .4 - Convulsão por Pentetrazol}

Utilizaram-se 24 animais, divididos em quatro grupos de seis. 0 primeiro grupo foi tratado com salina, o segundo com $5 \mathrm{mg} / \mathrm{kg}$ de diazepam e os demais com extrato de P.alata Dryand. $75 \mathrm{mg} / \mathrm{kg}$ e $150 \mathrm{mg} / \mathrm{kg}$. Após $60 \mathrm{mi}$ nutos todos os animais receberam $50 \mathrm{mg} / \mathrm{kg}$, i.p., de pente$\operatorname{traz01}$

\subsection{5 - Atividade Motora Espontānea}

Para a realização deste ensaio, ut $\underline{i}$ lizaram-se 30 animais, divididos em cinco grupos de seis, a saber: grupo controle, tratado com salina; dois grupos 
tratados, respectivamente, com $75 \mathrm{mg} / \mathrm{kg}$ e $150 \mathrm{mg} / \mathrm{kg}$ do extrato de P.alata Dryand.; um grupo tratado com $3 \mathrm{mg} / \mathrm{kg}$ de anfetamina e um grupo tratado concomitantemente com $3 \mathrm{mg} / \mathrm{kg}$ de anfetamina e $150 \mathrm{mg} / \mathrm{kg}$ do extrato.

Os movimentos foram registrados no decorrer de 90 minutos a partir do momento de cada aplicação, utilizando-se o aparelho descrito por oga et al. (47), constituído de: a) recepiente circular metāi ico de $20 \mathrm{~cm}$ de diàmetro na base e $25 \mathrm{~cm}$ de diāmetro no seu bordo superior com $10 \mathrm{~cm}$ de altura, onde o animal foi colocado; b) suporte dotado de 7 pinos metālicos, um central mais elevado e seis dispostos em circulo. Todos os pinos eram conectados atravēs de um fio metālico e um contador digitālico de impulsos elétricos. O recepiente era suspenso sobre o pino central mantendo-se uma distāncia de $2 \mathrm{~mm}$ entre a base inferior em posição horizontal e os pinos periféricos. A inclinação do recepiente para qualquer lado permitia o contato com dois pinos, fechando assim o circuīto elétrico. A movimentação do animal sobre o recepiente fazia com que o fechamento do cir cuíto fosse registrado como impulso no registrador.

\section{3 .6 - Toxicidade Aguda}

A toxicidade aguda do extrato de $\underline{P}$. alata Dryand. foi estimada através de determinação da dose letal $50 \%\left(\mathrm{DL}_{50}\right)^{\text {. }}$

Utilizaram-se 20 animais, divididos em quatro grupos de cinco. As doses do extrato aplicadas 
intraperitonialmente foram de: $300 \mathrm{mg} / \mathrm{kg}, 380 \mathrm{mg} / \mathrm{kg}, 432 \mathrm{mg} / \mathrm{kg}$ e $578 \mathrm{mg} / \mathrm{kg}$. Após a aplicação, os animais foram colocados em observação por um perĩodo de 24 horas.

$$
\text { O valor da } \mathrm{DL}_{50} \text { foi calculado pelo }
$$

método de Thompson (64).

\section{Estatistica}

A avaliação estatĩstica dos dados comparativos de duas médias foi feita com a aplicação do teste " $t$ " de Student pareado e não pareado, sendo adotados os nîveis de significāncia de $5 \%$. Na comparação de duas médias, utilizou-se anālise de variância, seguida do teste de Tukey, quando havia significância. 


\section{RESULTADOS}

\section{$4.1-B O T \hat{A} N I C A$}

\subsection{1 - Passiflora alata Dryander}

\section{Caracterização macroscōpica}

As folhas (Fig. 1) são simples, inteiras, de controno oval ou oval-oblongo, medindo quando adultas 8,0 a $20,0 \mathrm{~cm}$ de comprimento por 5,0 a $16,0 \mathrm{~cm}$ de 1 a $\underline{r}$ gura. 0 limbo, glabro, apresenta coloração verde escura na face superior e mais clara na inferior e consistencia membranācea a sub-coriācea. Tém o āpice acuminado, raramente agudo e a base variando entre arredondada, subcuneada e subcordada. As margens são inteiras, lisas, levemente onduladas e hialino-cartilagineas. O sistema de nervação é do tipo penivērveo com seis a oito nervuras secundārias de cada lado da principal, emergindo desta no terço inferior da folha, com àngulos entre 400 a 600 . Os pecĩolos medem de 2,0 a $10,0 \mathrm{~cm}$ de comprimento por 0,2 a $0,5 \mathrm{~cm}$ de diāmetro, apresentando-se canaliculados do lado da epiderme ventral e arredondados e ligeiramente carenados do lado dorsal. Em sua região basal, apresentam-se ligeiramentetor cidos e providos de estípulas lineares ou linear-lanceoladas, com 2,0 cm de comprimento por atē 1,0 cm de 1argura. Apa recem no pecĩolo 2 pares de gländulas de aspecto urceolado, sendo que 1 destes pares se localiza junto ao nivel de in- 


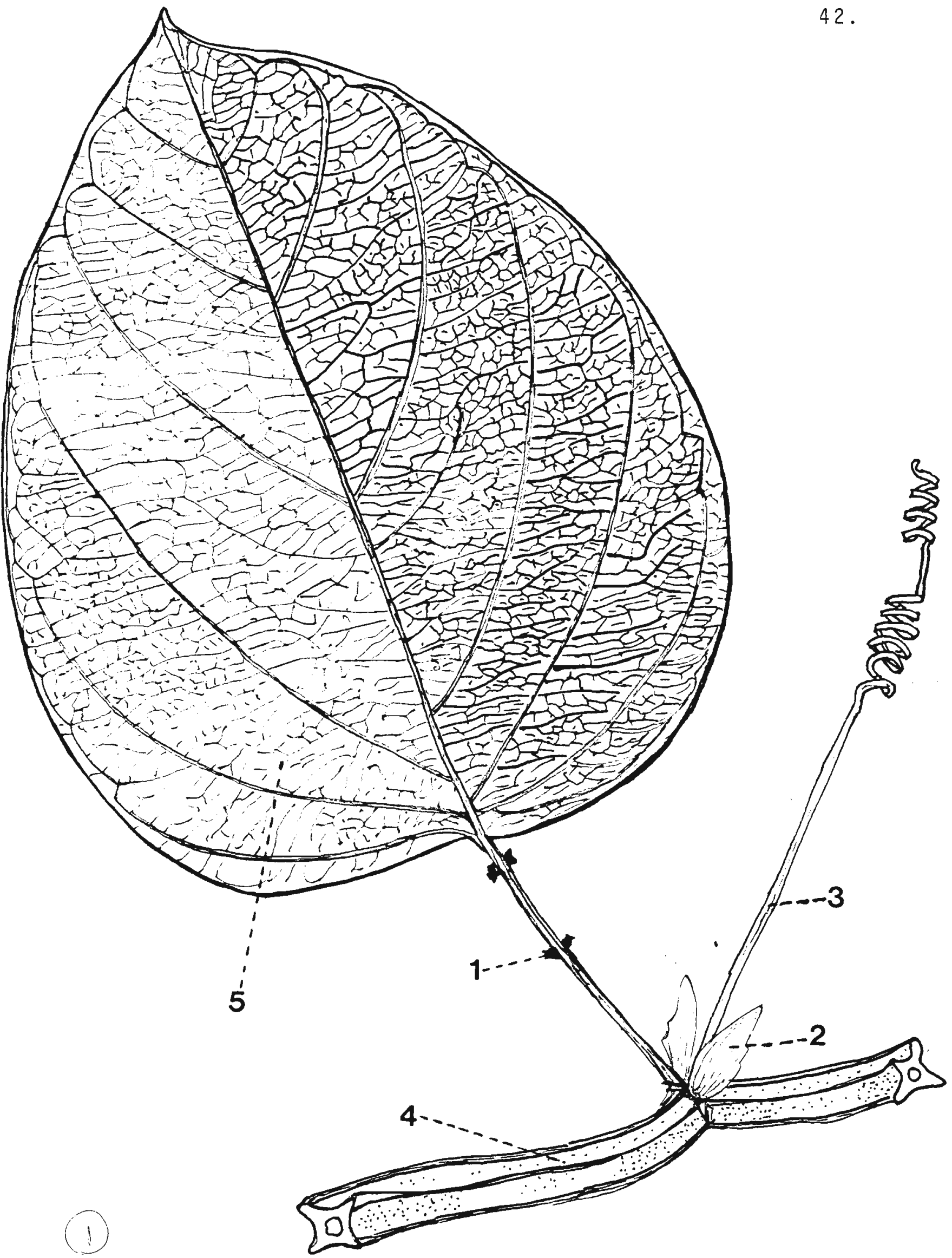

FIGURA 1 - Passiflora alata Dryand. 1-G1āndula; 2-Estípula; 3- Gavinha; 4-Caule; 5-Folha. 
serção da base do 1 imbo. A presença de gavinhas pode ser observada junto à base foliar (Fig. 1).

As folhas quando transformadas em droga, apresentam-se fragmentadas e com aspecto amarrotado. São inodoras, possuem coloração variando de verde amarelado a ligeiramente amarronzado e sabor amargo. Os pecíolos apresentam-se retorcidos e estriados longitudinalmente.

o caule è herbàceo, tetrangular, pro vido de àngulos alados (Fig. 1). Possui coloração esverdeada e apresenta regiões de nōs e entrenós bem diferencia das. Este örgão vegetal quando transformado em droga, apre senta-se estriado longitudinalmente, sua coloração é marrom esverdeada e quando observado em secção transversal mostra fístula evidente em sua região central.

\section{Caracterização microscōpica da folha}

A nervura mediana, vista em secção transversal (Fig. 2) apresenta-se biconvexa, sendo a saliência mais acentuada na região localizada do lado da epiderme inferior a qual assume aspecto carenado. As epidermes são constituídas de cēlulas irregulares na forma e de tamanho um pouco menor do que suas correspondentes da região do 1 imbo.

Tanto abaixo da epiderme superior como abaixo da epiderme inferior, observa-se a presença de maciço colenquimatoso formado por cēlulas com espessamento celulósico nos cantos (Fig. 2-Co.). 


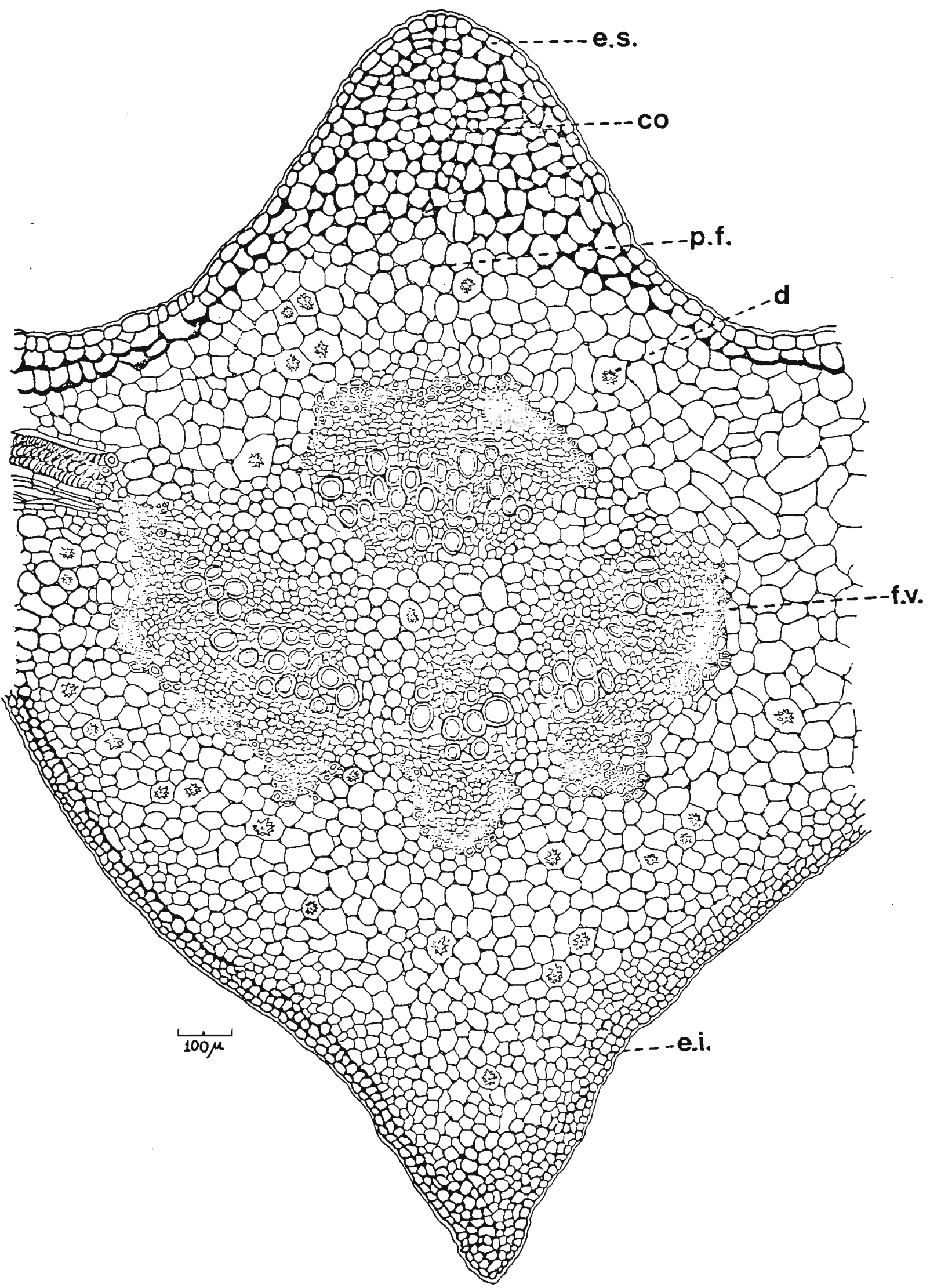

FIGURA 2 - Passiflora alata Dryand. Secção transversal da nervura mediana da folha. e.s.-epiderme superior; Co.-colênquima; p.f.-parênquima fundamenta 1; f.v.-fe $\underline{i}$ xe vascular; e.i.-epiderme inferior; d-drusa. 
o parēnquima fundamental, bem desen volvido, (Fig. 2-p.f.) contēm numerosas cēlulas providas de cristais estelares de oxalato de cālcio. o sistema libero-lenhoso é formado por quatro a seis feixes fibro-vasculares do tipo colateral, dispostos em semi-círculo, sepa rados entre si por estreita faixa de tecido parenquimático, e por um feixe maior localizado na região de abertura do arco formado pelos outros feixes. 0 limbo foliar em secção transversal ao nîvel do terço médio inferior da folha (Fig.3-B) mostra estrutura heterogēnea e assimétrica.

A epiderme superior (Fig. 3 -e.s.), é formada de cēlulas de contorno, aproximadamente retangular, alongadas tangencialmente, irregulares no tamanho e re cobertas por cuticula relativamente espessa e lisa. 0 parénquima paliçādico (Fig. 3-p.p.) é constituīdo por uma ou mais camadas celulares e sua espessura corresponde, aproxi madamente, a um terço do limbo foliar. o parénquima lacunoso, relativamente frouxo (Fig. 3-p.1.) é formado por seis a oi to camadas celulares. A epiderme inferior (Fig.3-e.i.) e integrada por cēlulas semelhantes àquelas descritas para epiderme superior, diferindo destas pelo tamarho, algo menor. Nesta epiderme observa-se a presença de estōmatos $1 \underline{0}$ calizados no mesmo nível que as demais cēlulas ep' lérmicas. Drusas podem ser observadas em todo mesofilo, especialmente na região do parênquima lacunoso. A presença de feixes vas culares delicados (Fig. 3-f.v.) pode ser notada na região mediana do mesofi10. 
46.
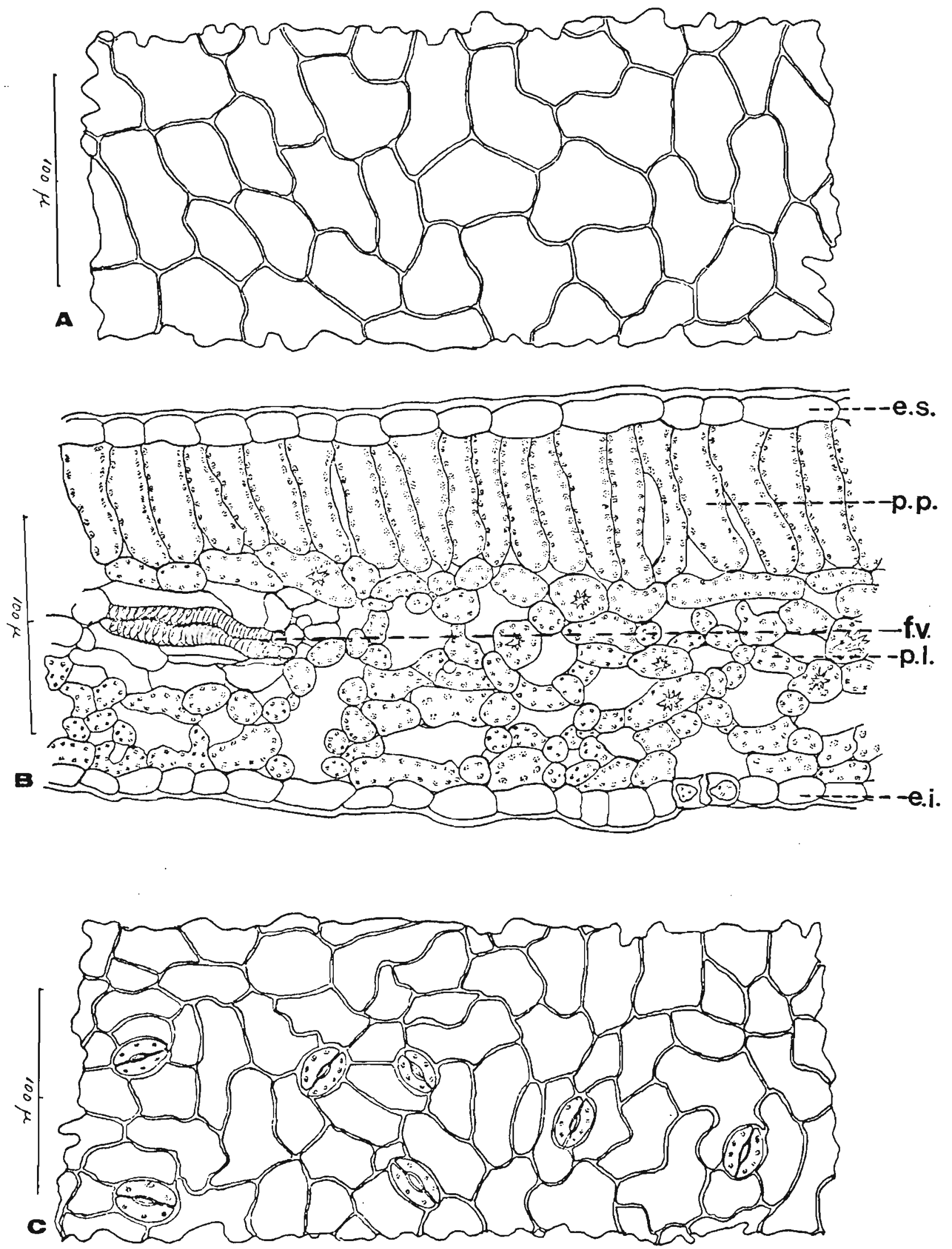

FIGURA 3 - Passiflora alata Dryand: : A- epiderme superior da folha vista de face; B- secção transversal da folha: e.s-epiderme superior; p.p-parênquima paliçādico; p.lo-parēnquima 1 acunoso; f.vo-feixe vas cular; e.i-epiderme inferior. C-epiderme inferior da folha vista de face. 
As epidermes são glabras. Vistas

de face (Fig. 3-A e C) apresentam cêlulas de contorno pol gonal, de paredes levemente ondeadas na face superior e si nuosas na inferior. Os estómatos são do tipo anomocítico e ocorrem exclusivamente na face inferior.

0 peciolo, quando observado em secção transversal, (Fig. 4-A, B e C) apresenta-se provido de saliência careniforme, localizada do lado da epiderme infe rior e de sulco do 1 ado da epiderme superior, o qual è bem evidente junto a base do 1 imbo, tornando-se cada vez menos patente a medida que nos aproximamos do seu ponto de inser ção no caule.

A epiderme apresenta características semelhantes às da região da nervura mediana, jā descritas. Abaixo da região epidērmica ocorre região colenquimātica (Fig. 4) em forma de anel contínuo. 0 parénquima funda mental, relativamente bem desenvolvido, possui numerosas células contendo cristais estelares de oxalto de cālcio.

O sistema vascular é bem desenvolvi do e característico. Na região distal ao ponto de inserção do 1 imbo, apresenta-se constituĩdo por onze feixes fibro-vasculares dispostos em semi-circulo, auase unidos entre si e por outros quatro. Destes, dois acham-se localizados na região das alas, um de cada lado, junto a epiderme adaxial. Os outros dois encontram-se enfileirados na região mediana da estrutura localizando-se, o de maior por te, na abertura do arco formado pelo conjunto de feixes jā descritos. 


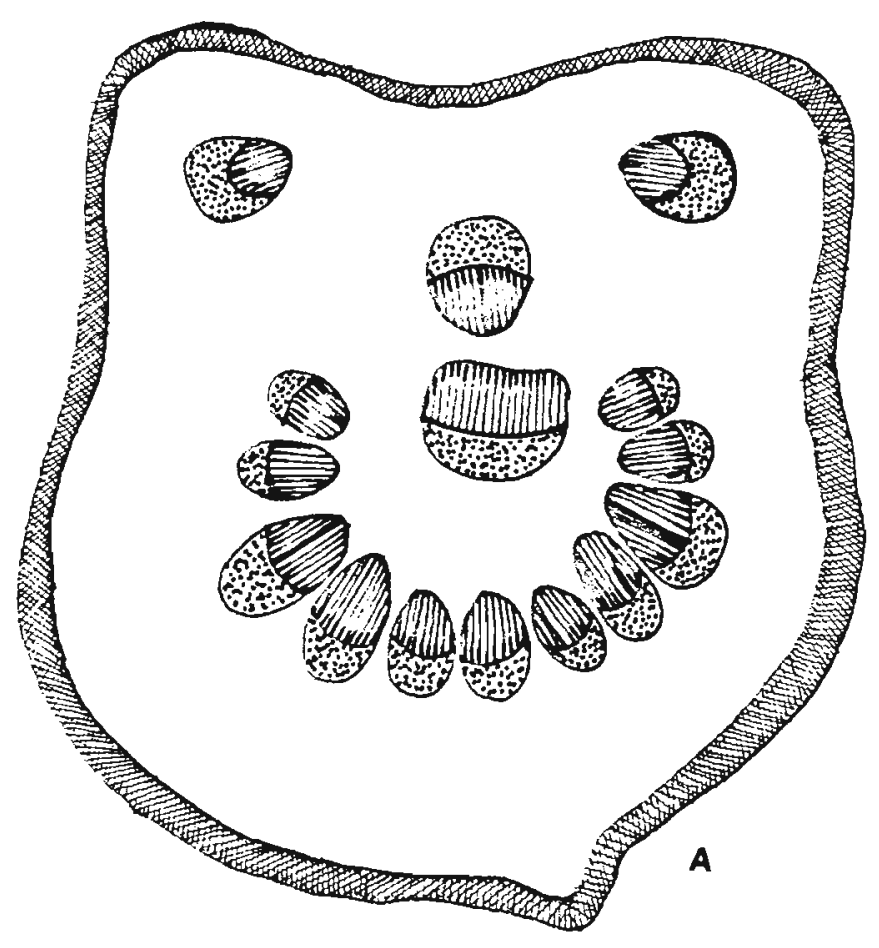

48.
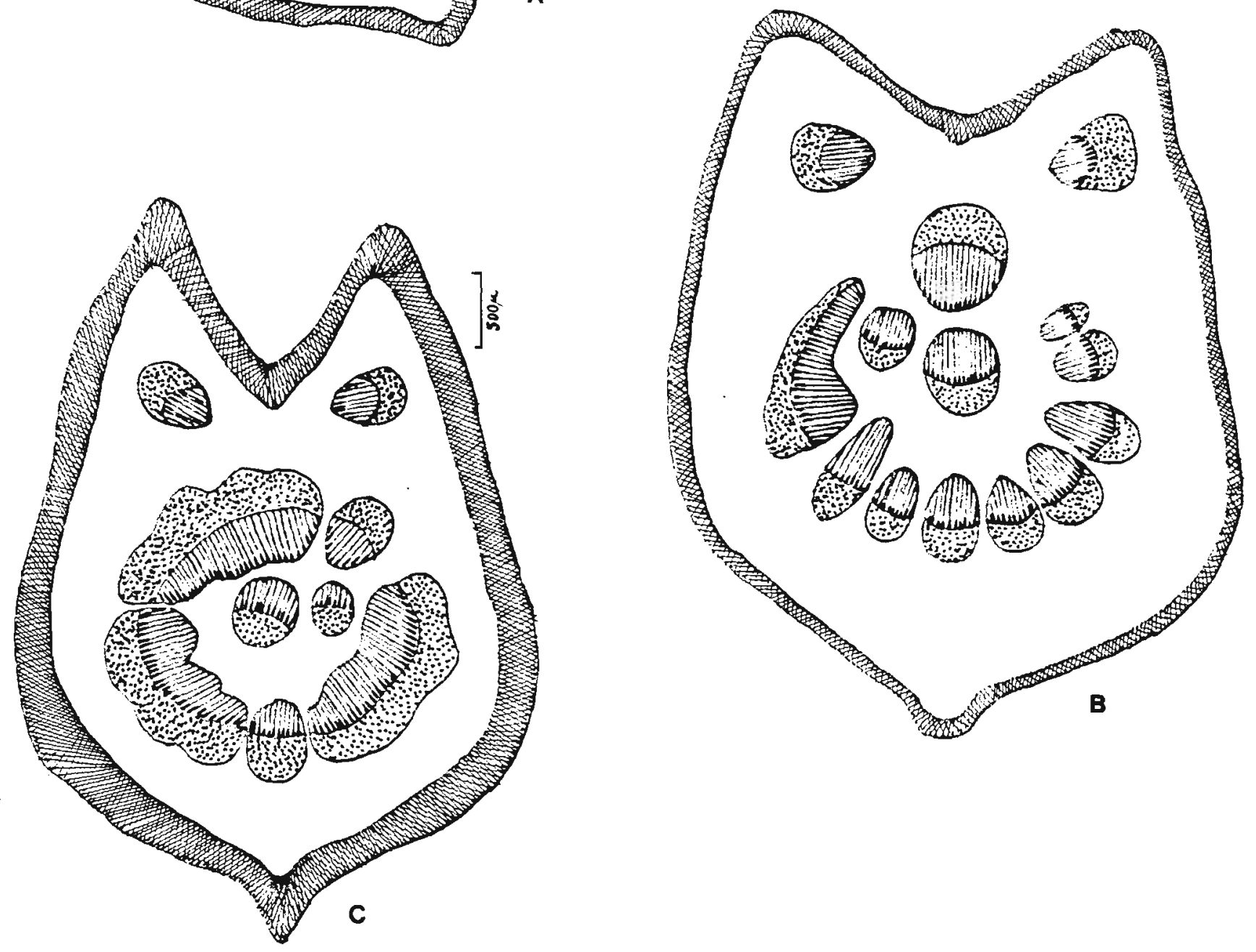

FIGURA 4 - Passiflora alata Dryand.. Seções transversais do pecíolo. A-próximo da insersão no caule. B- sec ção da região mediana. c- prōximo à lämina foliar. 
Na região mediana $(F i g .4-B)$ do peciolo, dois feixes do conjunto disposto em arco se fundem para formar um feixe vascular e um outro sofre descolocamento de maneira a se localizar junto aos dois outros feixes enfileirados e localizados na região mediana.

Na região superior do pecĩolo (Fig. 4-C), junto à inserção do limbo foliar, o sistema vascular é representado por um círculo de feixes Tocatizados uns bem prōximos dos outros, com exceção de um, que é separado do con junto por faixa de tecido parenquimático um pouco mais lar ga. Na região medular delimitada pelo cĩrculo de feixes, pode ser observada a presença de dois feixes vasculares. Ou tros dois são notados na porção cortical na região de cada ala formada junto à epiderme adaxial.

\section{Caracterização microscōpica do caule}

O caule de P.alata Dryand. possui estrutura do tipo eustética sendo os feixes vasculares do tipo colateral (Fig. 5). Secção transversal do örgão, logo abaixo do broto terminal, possui contorno alado-quadrangu$\operatorname{lar}(\mathrm{Fig} \cdot 7)$.

A epiderme (Fig. 6-e) da região $10-$ calizada entre as alas é glabra, constituĩda de células de contorno arredondado frequentemente achatadas no sentido periclinal e recobertas por cuticula lisa.

o colēnquima (Fig. 6-Co.) lacalizado logo abaixo desta região epidérmica é representado por 
50.

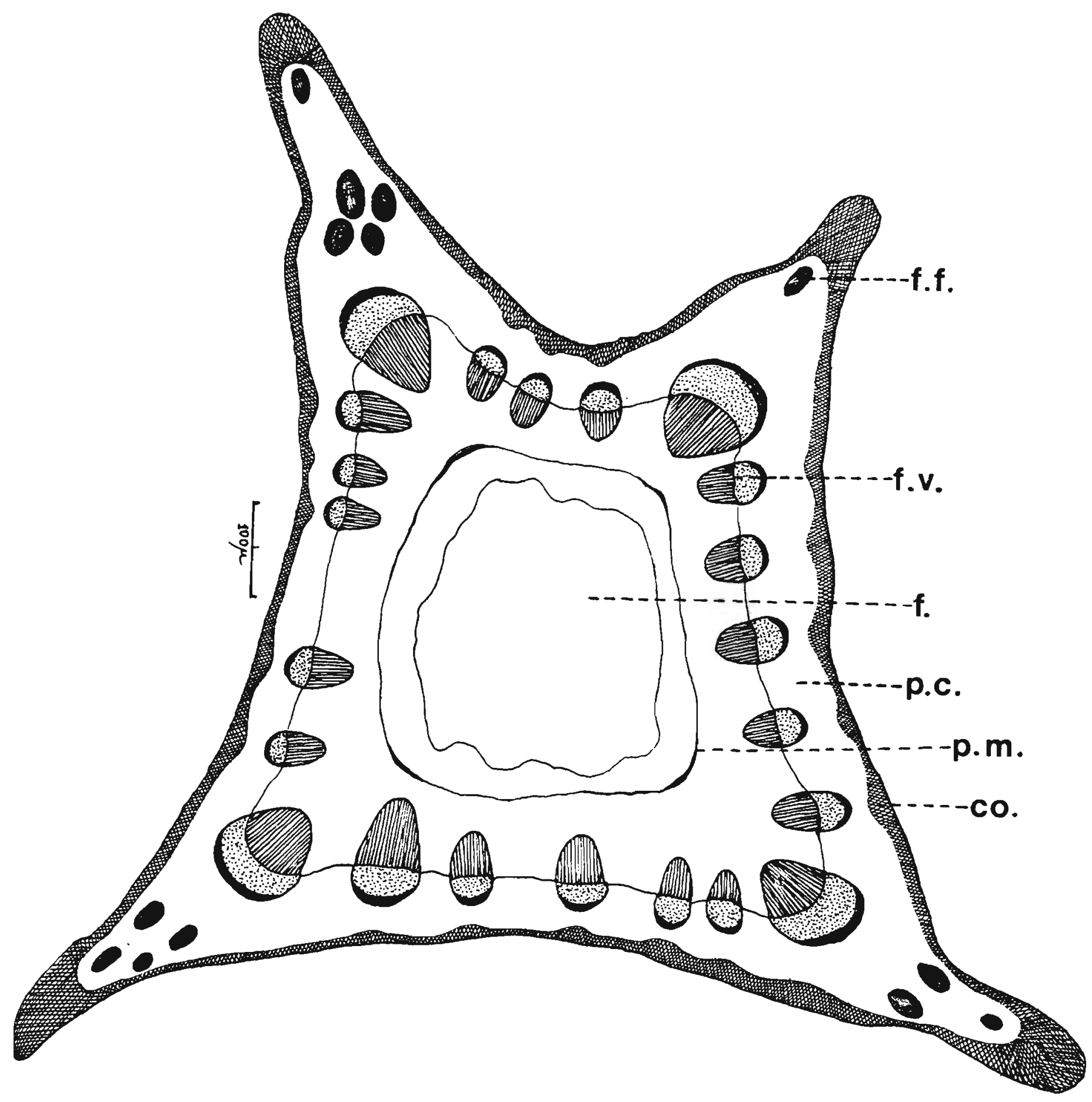

FIGURA 5 - Passiflora alata Dryand. Desenho esquemātico de secção transversal do caule próximo à gema terminal; Co-colēnquima; f.f.-feixe-fibroso; f.v. feixe vascular; p.m.-medula; p.e.-parênquima cor tical; f.-fistula. 
quatro a seis fileiras de cêlulas de tamanho maior do que as epidērmicas e providas de espessamento celulósico nos cantos.

0 parẽnquima cortical (Fig. 6-p.c.)

é pouco desenvolvido, sendo constituído por seis a dez fileiras de cēlulas de contorno arredondado, deixando entre sí espaços intercelulares do tipo meato, cujo tamanho aumenta no sentido da periferia para o centro da estrutu ra.

o endoderme (Fig. 6-en.) não è característica, sendo constituída de células providas de con teūdo amilîffero. A região colenquimātica neste local fica quase que exclusivamente relacionada com o topo da ala. o parēnquima cortical nesta região é bem desenvolvido e in clui de um a quatro grupos de fibras em cada ala.

o periciclo é fibroso (Fig.6-p.fi.), descontīnuo e em forma de calota, encontrando-se relaciona do com a região floemātica dos feixes vasculares. A região floemātica é bem desenvolvida. Tubos crivados e placascri vadas bem desenvolvidas podem ser observadas nesta região, relacionados com cēlulas companheiras e parénquima do floe ma. A região cāmbial é bem evidente. 0 xilema (Fig.6-x.) e representado por vasos dispostos em fileiras radiais e parénquima xilemātico integrado por cēlulas de paredes pou co espessadas e por fibras localizadas especialmente nas regiões de origem secundāria. 


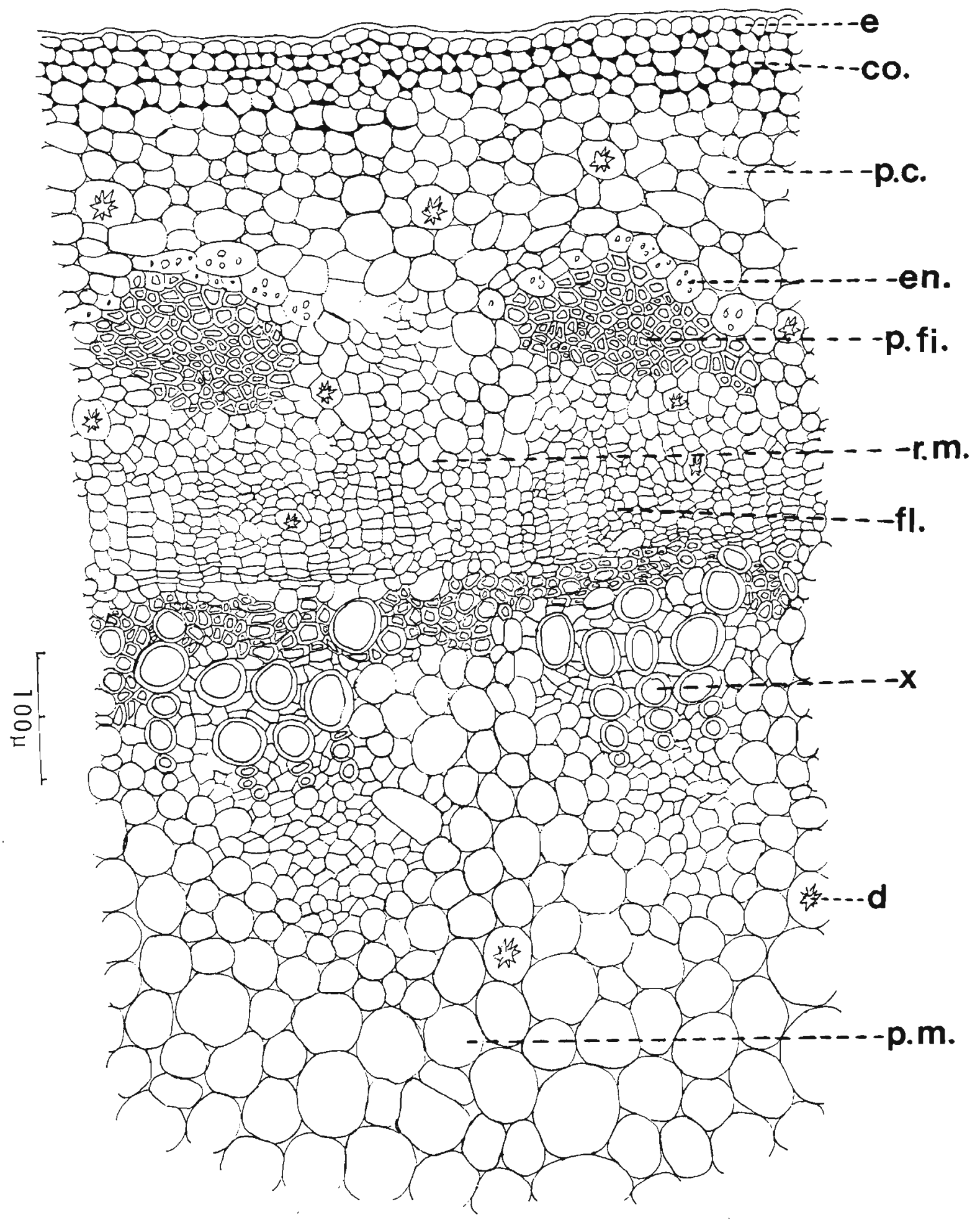

FIGURA 6 - Passiflora alata Dryand. Secção transversal do caule-região entre as alas; e-epiderme; co-colen quima; p.c-parénquima cortical; en-endoderme; r.m.raio medular; p.m-parēnquima medular; p.f-periciclo fibroso; fl.-floema; x-xilema; d-drusa. 


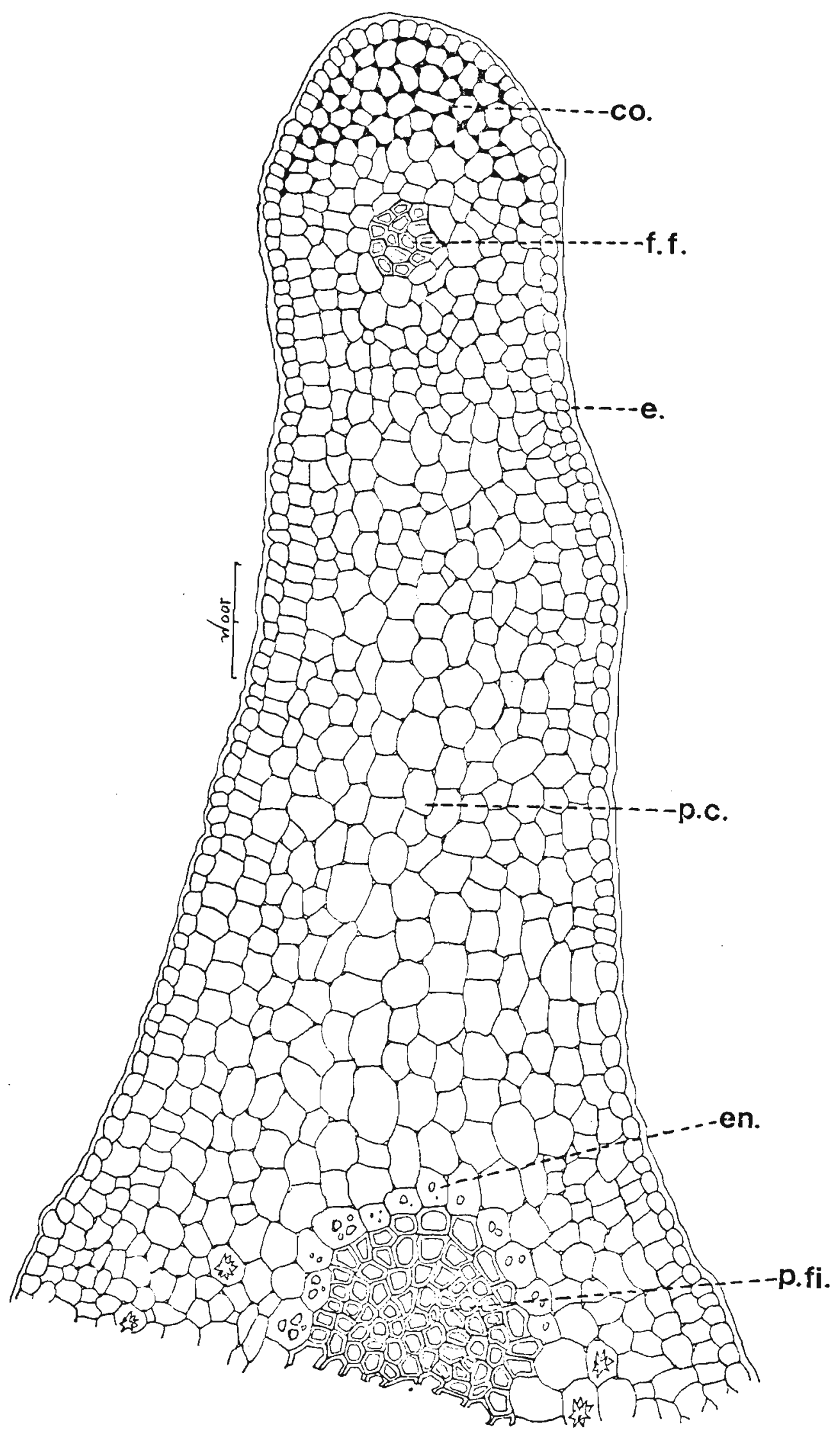

53. 
Separando os feixes vasculares observa-se a presença de raios medulares (Fig. 6-r.m.), providos de oito a dez fileiras de cêlulas em largura. 0 parênquima medular (Fig. 6-p.m.) è bem desenvolvido e suas c $\vec{e} 1$ ulas aumentam de tamanho da periferia para o centro da estrutura, onde observa-se com frequéncia a presença de fistula.

Drusas podem ser observadas em todas as regiões parenquimāticas da estrutura.

\section{1 .2 - Passiflora quadrangularis L.}

\section{Caracterização macroscōpica}

As folhas são simples, inteiras, de contorno ovalado ou oval-oblongo medindo, quando adultas de 10,0 a $20,0 \mathrm{~cm}$ de comprimento por 8,0 a $15,0 \mathrm{~cm}$ de 1 argura, (Fig. 8) de cor verde claro. A fase superior é um pouco mais clara que a inferior. 01 imbo é glabro, de consistên cia membranácea a sub-coriācea, tem āpice abrutamente acuminado e base arredondada a sub-cordada. Suas margens são inteiras, 1isas. Apresenta nervação do tipo peninérvico com a nervura principal proeminente na fase dorsal, formando no terço inferior àngulos de 609 a 700 com as nervuras secundārias. Estas, em nūmero de 10 a 12 de cada 1 ado, conferem à folha aspecto rugoso. Os peciolos medem de 2,0 a 5,0 cm de comprimento e são canaliculados do lado da epi derme superior e agudamente carenados do lado inferior. Apresentam 6 giāndulas que aparecem aos pares, 2 das quais 
prōximas à inserção do limbo. Na base do pecíolo aparecem estipulas ovais ou oval-lanceoladas de 2,0 a $3,5 \mathrm{~cm}$ de comprimento por 1,0 a $2,0 \mathrm{~cm}$ de 1 argura. Nas axilas das folhas, observa-se a presença de gavinhas (Fig. 8).

As folhas quando transformadas em droga, são friāveis, apresentam aspecto amarrotado e colo ração verde-amarelada. São praticamente inodoras, possuindo sabor amargo.

o caule è herbāceo, tetrangular, apresentando os àngulos alados. Possue coloração verde - clara com os nōs e entre-nōs bem diferenciados. Na droga apresen ta-se nitidamente estriado no sentido longitudinal e sua secção transversal deixa ver medula fistulosa.

\section{Caracterização microscōpica}

Secções transversais da folha ao nị vel do terço médio inferior apresenta mesofilo heterogéneo e assimëtrico. A epiderme superior (Fig. 9-e.s.), ē repre sentada por uma fileira de células, de contorno aproximada mente retangular, alongadas no sentido periclinal e de tamanhos variāveis. Esta epiderme glabra é provida de cutícula 1 isa.

o parēnquima paliçādico (Fig.9-p.p.)

é formado por uma fileira de células cujo comprimento representa a metade da extensão do mesōfilo. o parēnquima la cunoso (Fig. 9-p.1.) è representado por 7 a 10 fileiras de cēlulas que se dispõem de forma pouco compacta. 


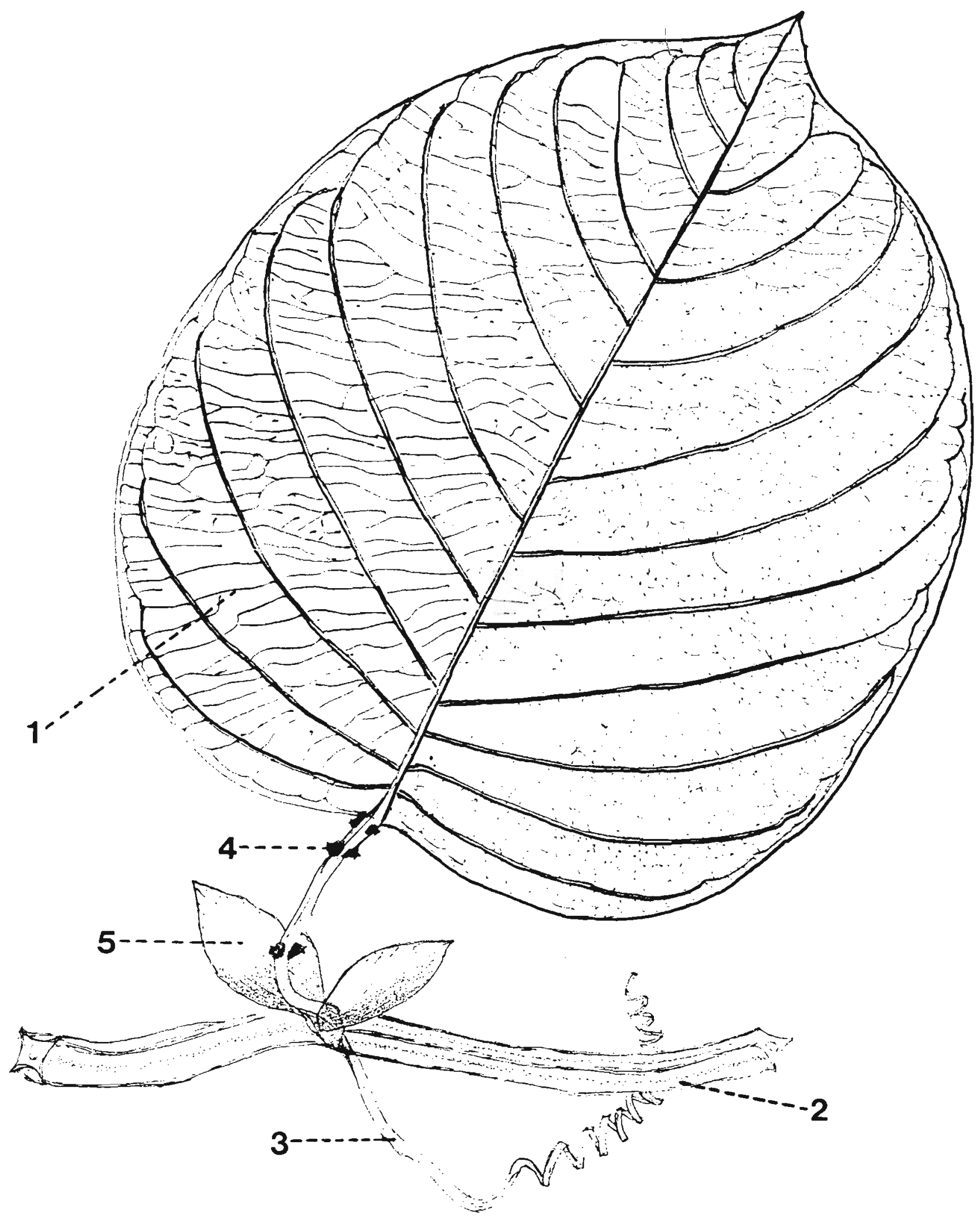

FIGURA 8 - Passiflora quadrangularis L.: 1-folha; 2-caule; 3-gavinha; 4-gavinha; 5-estípula. 
Feixes vasculares (Fig. $9-f . v$.$) de-$ i icados localizados na região mediana no mesofilo podem ser observados.

A epiderme inferior (Fig. 9-e.i.) a presenta-se formada por cēlulas providas de caracteristicas semelhantes àquelas mencionadas para a epiderme superior diferindo desta especialmente pelo tamanho, que é al go menor e pela presença de estômatos. Drusas podem ser observadas em toda a região do mesofilo.

A Figura $9 \mathrm{~A}$ representa a epidermesu perior vista de face. Nela podem ser observadas cēlulas de contorno aproximadamente poligonal, e a Fig. $9 \mathrm{C}$ representa a epiderme inferior em visão paradérmica mostrando cēlulas de contorno sinuoso. Estōmatos providos de duas a três cēlulas paraestomatais podem ser observados.

Secção transversal da nervura media na ao nível do terço médio inferior (Fig. 10) mostra epiderme superior e epiderme inferior com caracteristicas semeihantes às correspondentes já descritas para região do 1imbo. Abaixo das epidermes pode ser observada a presença de células colenquimāticas (Fig. 10-Co.) providas do espes samento nos àngulos. O parênquima fundamental é bem desen volvido e envolve complexo vascular disposto em dois conjuntos. 0 primeiro conjunto dispõe-se em forma de arco com a abertura para o lado da epiderme superior. 0 segundo conjunto dispõe em forma de circulo localizando-se na abertura do arco formado pelo conjunto de feixes jă descrito (Fig. 10). 

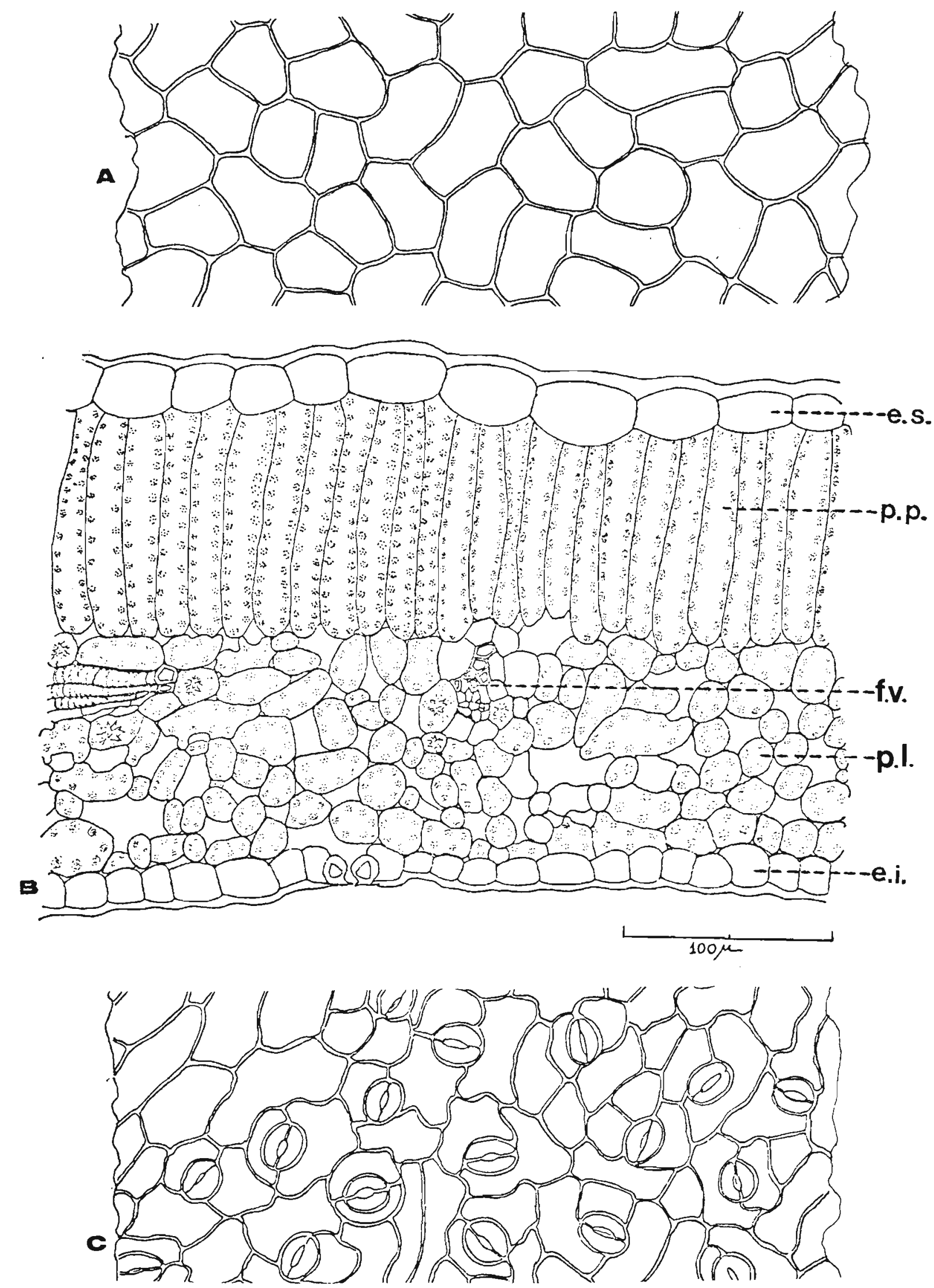

FIGURA 9 - Passiflora quadrangularis L.. A- epiderme superior da folha; vista de face. B- secção transversal do 1 imbo foliar: e.s.-epiderme superior; p.p.-parênquima paliçādico; p.1.-parēnquima lacunoso; f.f.-feixe vascular; e.i.-epiderme infe rior; e.-estōmato. C- epiderme inferior da folha, vista de face. 


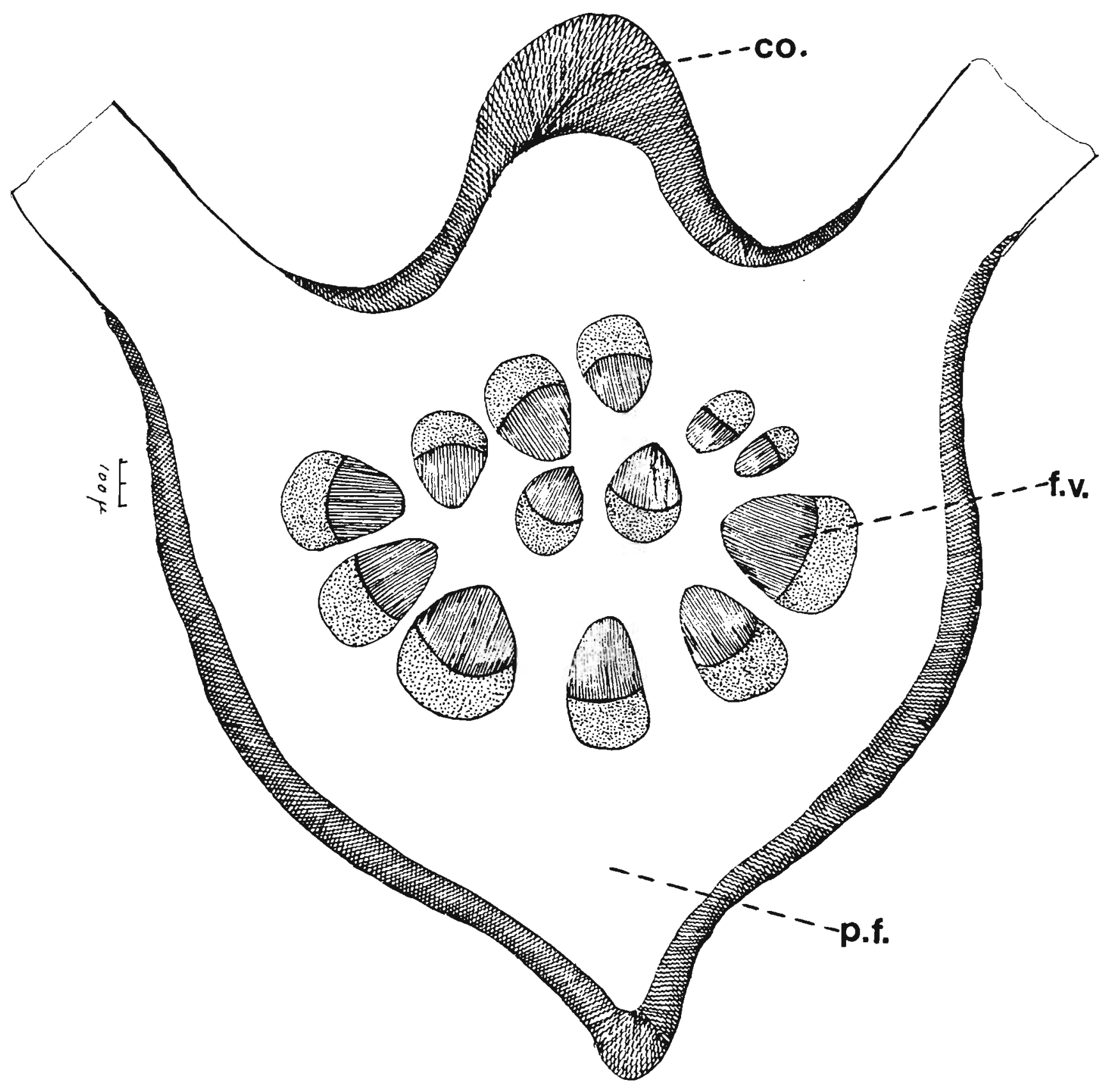

FIGURA 10 - Passiflora quadrangularis L. - Esquema de corte transversal da nervura mediana ao nível do terço médio inferior da folha. Co-região de colênquima. f.v.- feixes vasculares. p.f. parēnquima fundamental. 
60.

A Figura 11 representa parte do con junto de feixes dispostos em círculo. Nela pode ser obser vada a presença de feixes vasculares (Fig.11-f.v.) do tipo colateral separados entre si por raios parenquimáticos (Fig. $11-r \cdot p \cdot)$.

A Figura 12 representa região colen quimātica localizada abaixo da epiderme superior.

o peciolo cortado transversalmente nas regiões basal, mediana e distal, considerada a inserção no caule (Fig. 13), apresenta um conjunto de feixes vascula res com disposição circular rodeando 1 ou 2 feixes centrais. Na parte superior se dispõem 2 outros feixes cada um aloja do nas alas que se formam pela presença de canaleta peciolar.

\section{Caracterização mi croscópica do caule}

o caule de P.quadrangularis L. possui estrutura eustêlica sendo os feixes vasculares do tipo colateral (Fig. 14).

Secção transversal deste ōrgão logo abaixo do broto terminal possui contorno alado quadrangu$\operatorname{lar}$ (Fig. 15). A epiderme (Fig. 15-e) é constituída de cé lulas de contorno arredondado ou ligeiramente achatado alongado, ora no sentido radial, ora no sentido tangencial. o colēnquima (Fig. 15-Co.) è pouco desenvolvido sendo consti tuĩdo de cēlulas com espessamento nos āngulos. O parēnqui ma cortical (Fig. 15-p.c.) é pouco desenvolvido e envolve 


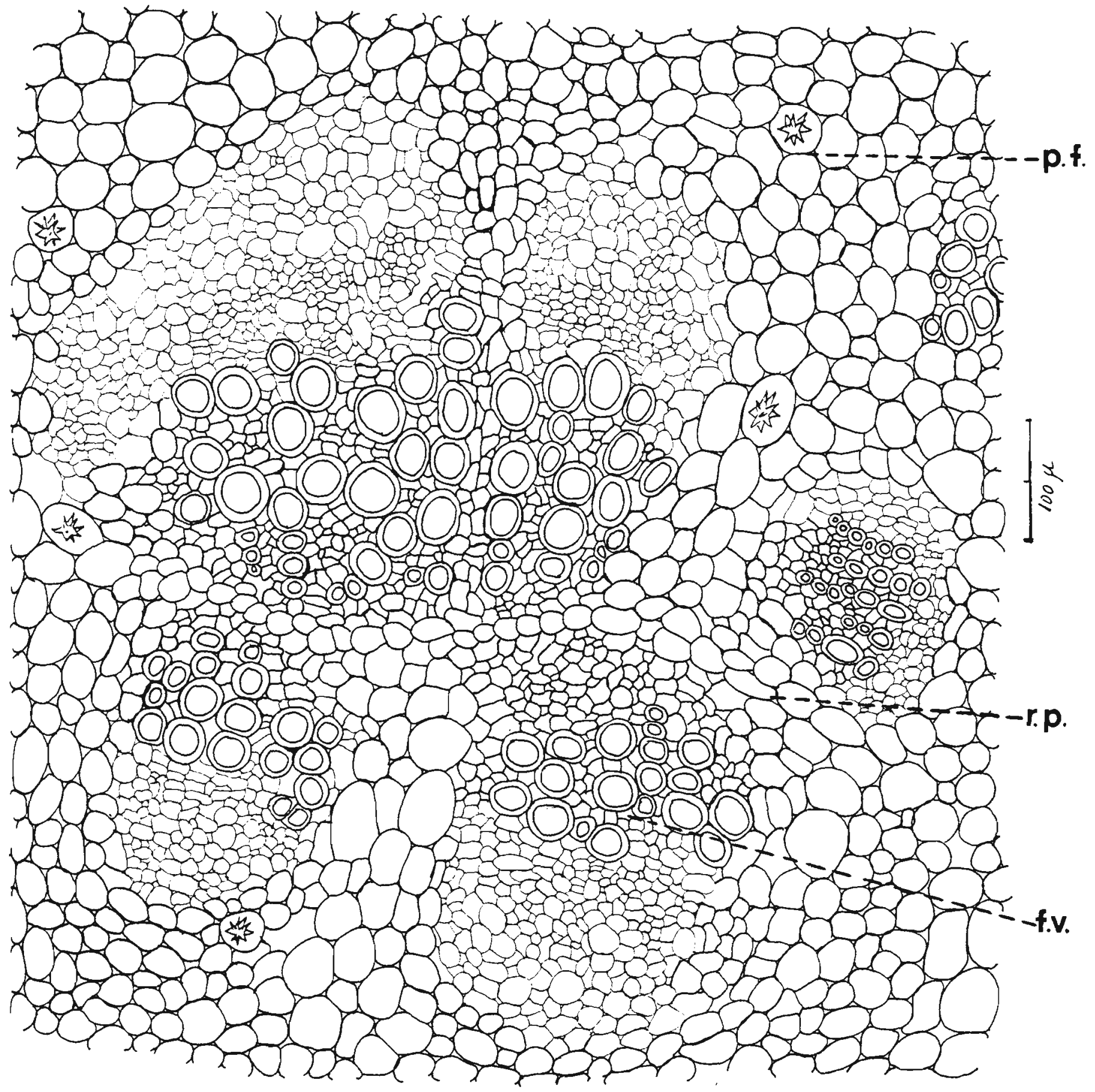

FIGURA 11 - Passiflora quadrangularis L. - Desenho da região central da nervura mediana destacando os feixes vasculares: p.f.- parēnquima fundamental.f.v.-feixe vascular; r.p.-raio parenquimá tico. 


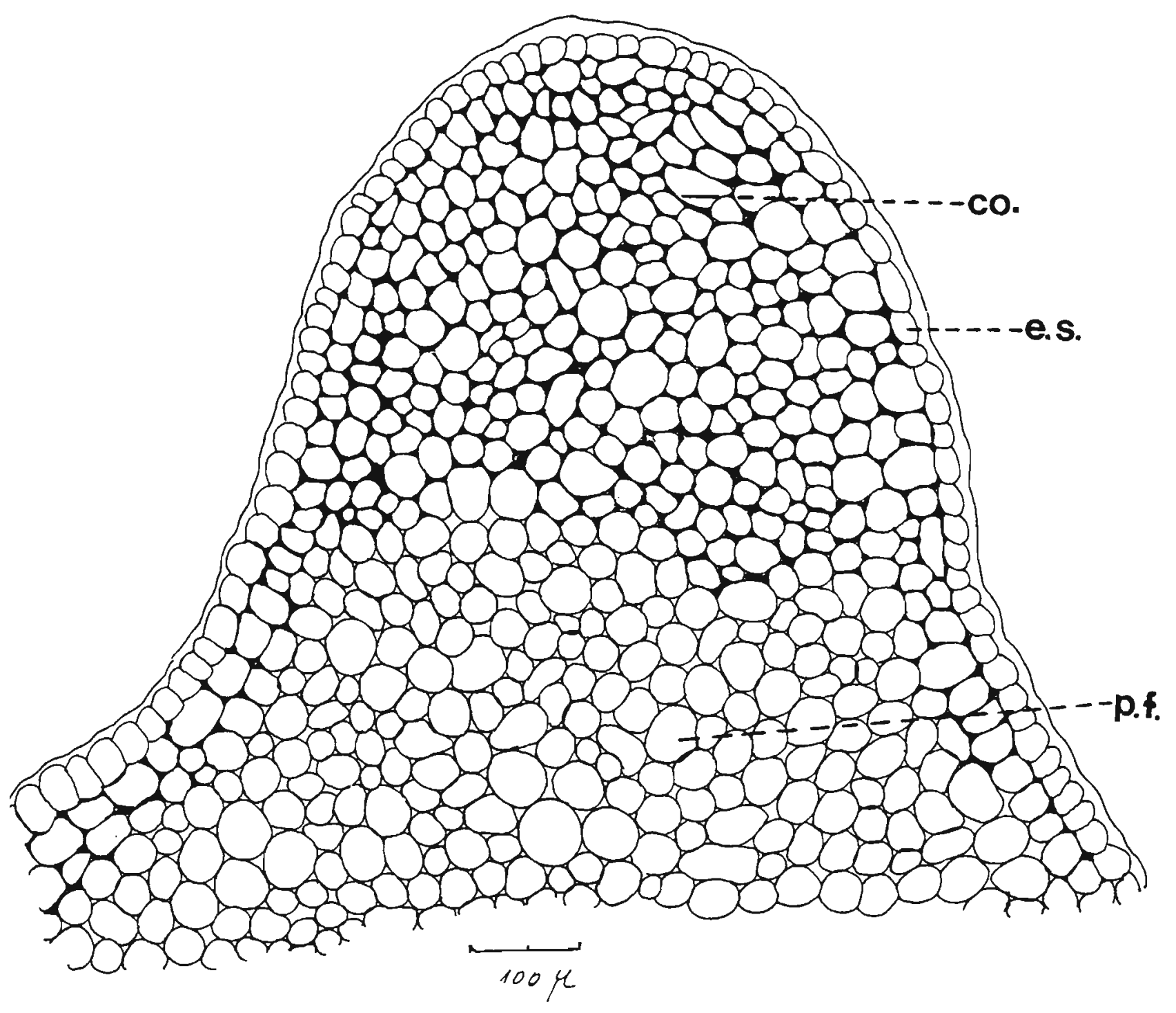

FIGURA 12 - Passiflora quadrangularis L. - Região da carena: e.s.- epiderme superior; Co. - colēnquima; p.f.- parênquima fundamental. 

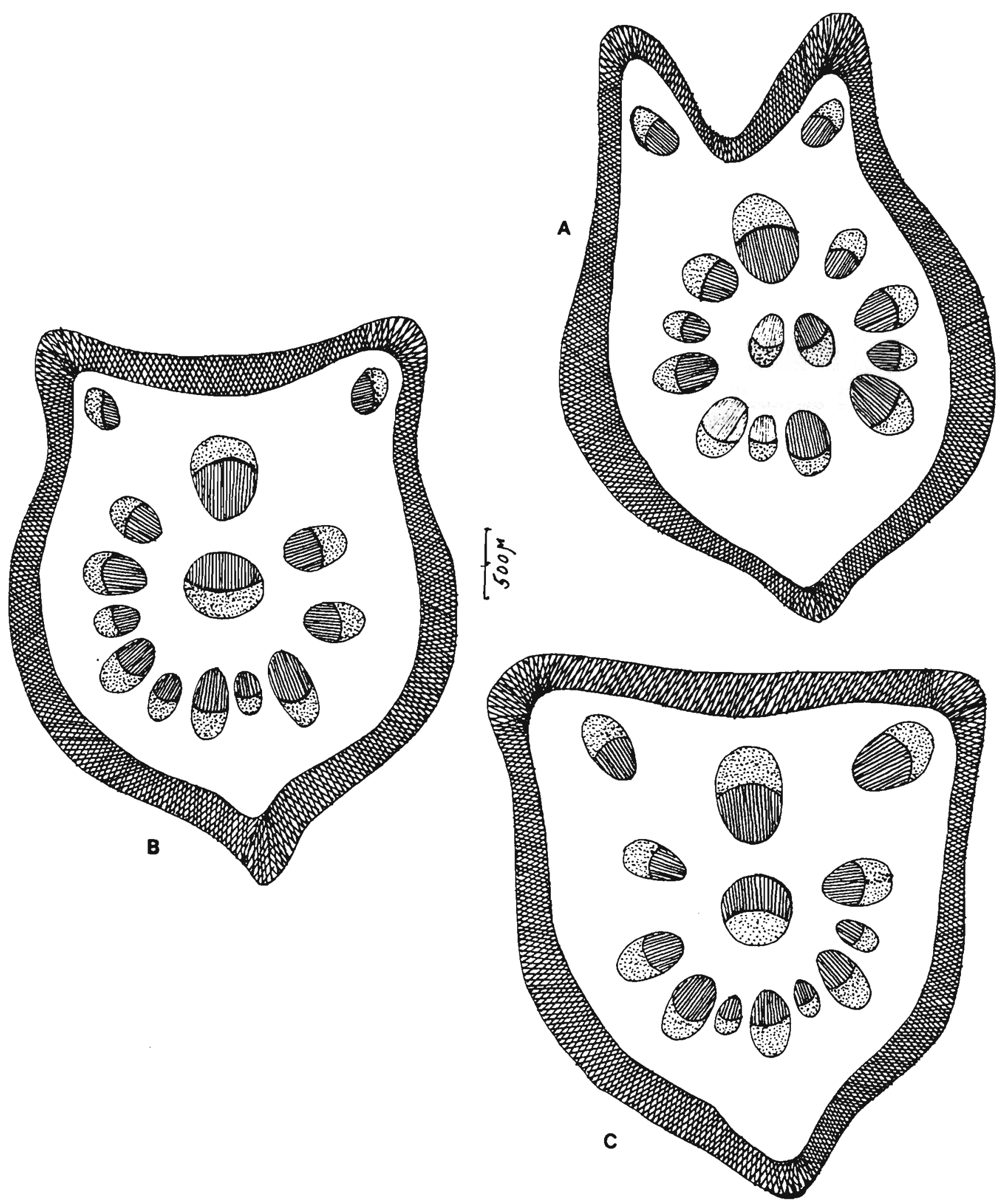

FIGURA 13 - Passiflora quadrangularis L. - Secçōes transver sais do peciolo; A- região prōxima a inserção da lâmina foliar; B- região mediana; C- região prō xima a inserção no caule. 


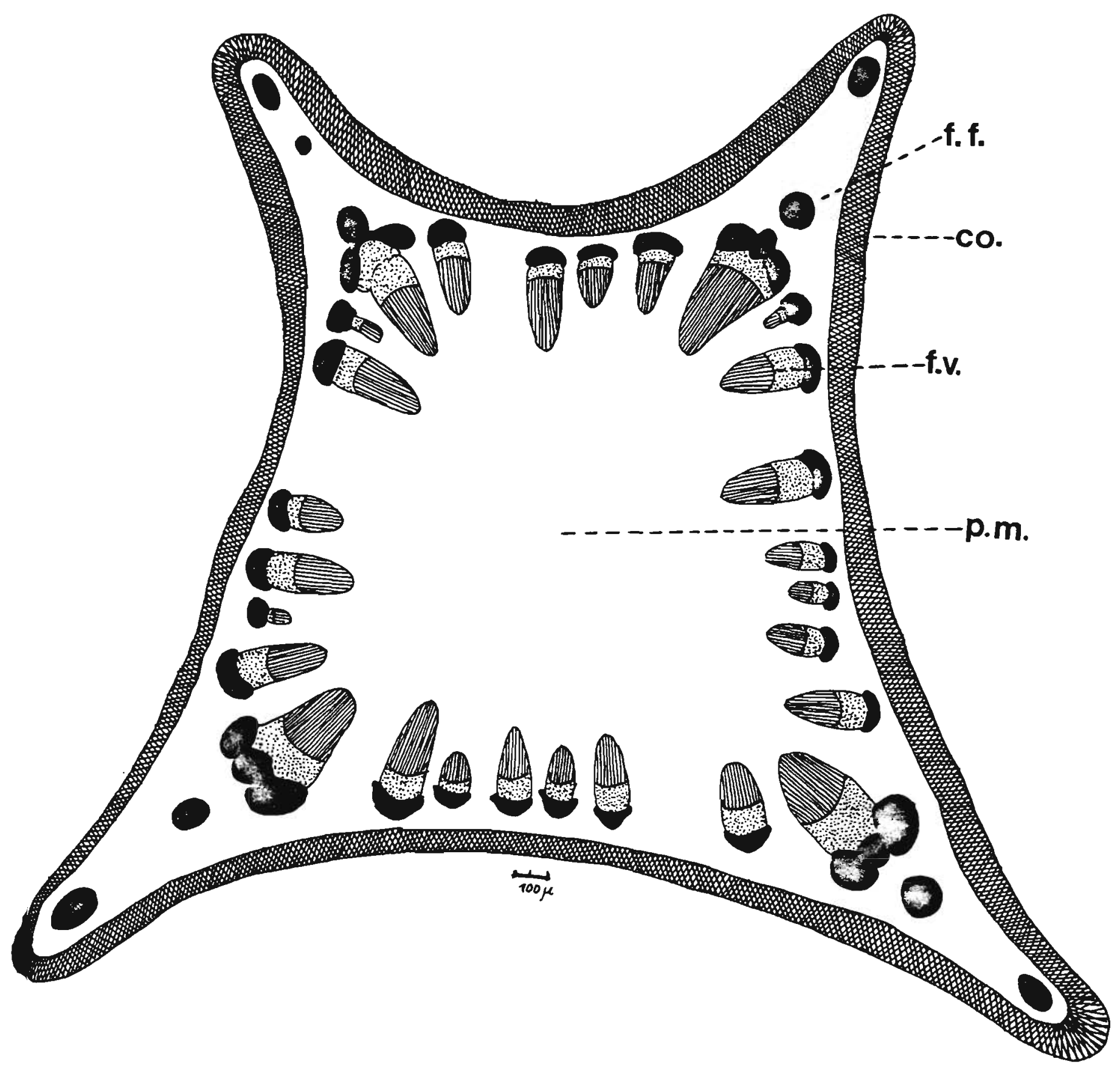

FIGURA 14 - Passiflora quadrangularis L. - Desenho esquemá tico de seç̧ão transversal do caule: co- colēn quima; f.f.- feixe fibroso; f.v.-feixe vascular; p.m.- medula. 
na região das alas, feixes de fibras dispostos em conjuntos de contorno arredondado.

A endoderme (Fig. 15-en.) não è caracteristica. 0 periciclo (Fig. 15-p.fi.) è descontínuo, fibroso e em forma de calota. Acha-se relacionado com os feixes vasculares,os quais constituídos de região floemāti ca (Fig. 15-f1.) bem desenvolvida representada por tubos crivados, células companheiras e abundante parēnquima. A região cambial ē bem visível e o xilema é representado por vasos dispostos em filas radiais separadas entre si por te cido parenquimātico (Fig. 15-x.). Fibras podem ser observadas nesta região.

Separando os feixes vasculares observa-se a presença de raios medulares relativamente estreitos. o parénquima medular (Fig. 14-p.m.) è bem desenvolvido. Drusas podem ser observadas em todas as regiões parenquimāticas.

\section{1 .3 - Passiflora edulis sims.}

\section{Descrição macroscōpica}

As folhas do vegetal eão simples,gla bras e caracteristicamente trilobadas (Fig. 16). Com certa frequência observa-se o fenōmeno de heterofilia, podendo ser observada a presença de folhas inteiras e de folhas bilobadas. São arredondadas possuindo base cordada, cunea da ou subtruncada e āpice variando do agudo ao acuminado. 


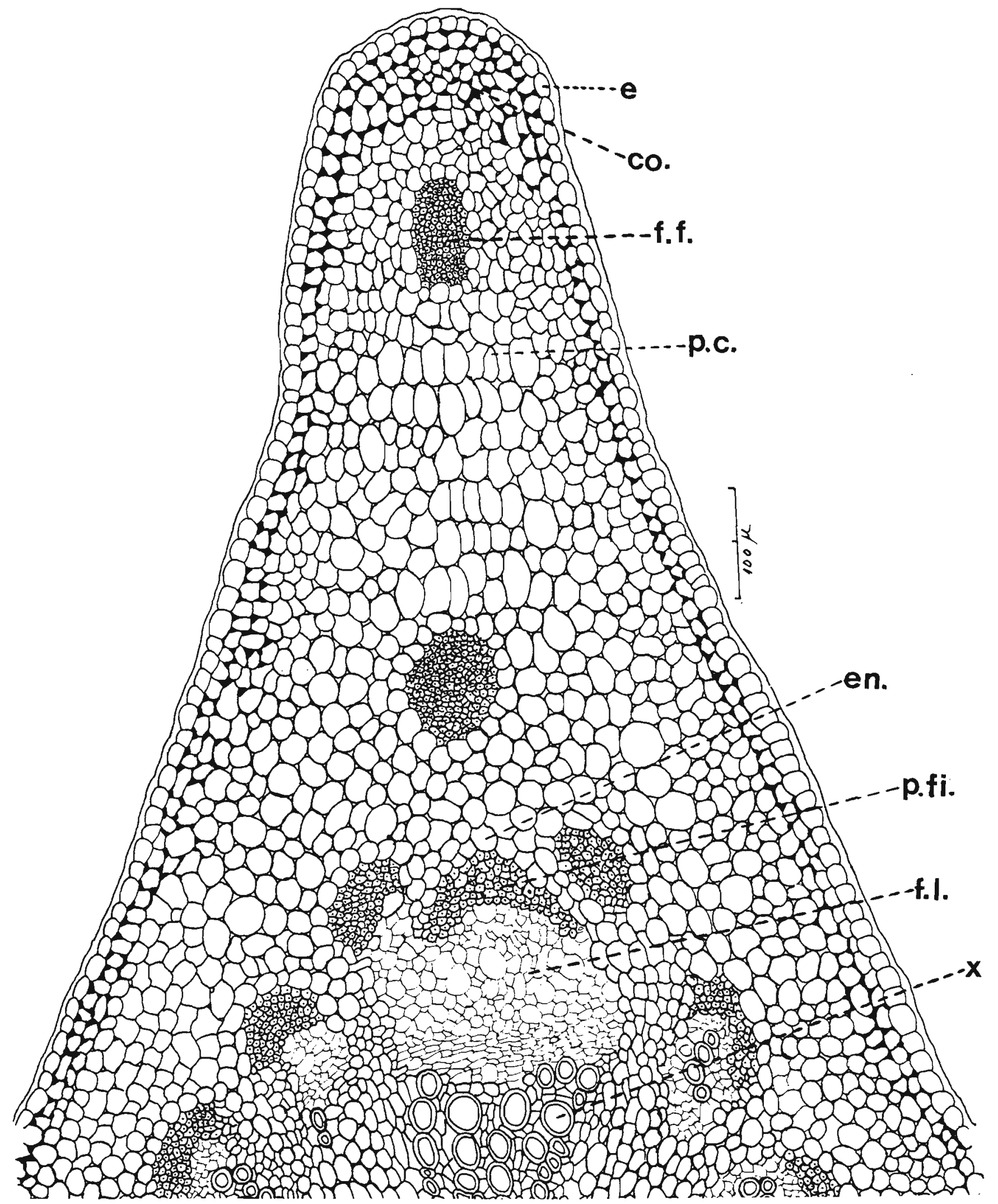

FIGURA 15 - Passiflora quadrangularis L. - Secção transversal do caule - Região da ala: e.-epiderme; cocolēnquima; f.f.-feixe fibroso; p.c.-parēnquima cortical; en.-endoderme; p.fi.-periciclo fi broso; fl.-floema; $x$-xilema. 
Apresentam margem serrilhada e consistencia variando de subcoriācea a membranācea. São trinervadas e medem de 4,0 a $13,5 \mathrm{~cm}$ de comprimento por 4,0 a $14,5 \mathrm{~cm}$ de 1 argura. $0 \mathrm{~s}$ lobos apresentam contorno subelipticos ou ovado elipticos. As regiões dos sinus do limbo foliar presentam-se arredondadas ou menos frequentemente subagudas. Os peciolos medem atē $7 \mathrm{~cm}$ de comprimento e são providos de duas glândulas sésseis localizadas junto à lāmina foliar. As estipulas apresentam forma linear-subulada e medem cerca de até $1 \mathrm{~cm}$ de comprimento. O caule é cilindrico ligeiramente estriado longitudinalmente, podendo apresentar-se fistuloso. Gavinhas podem ser observadas inserindo-se na axila foliar (Fig. 16).

A planta quando transformada em dro ga apresenta-se em pedaços providos de folhas amarrotadas de coloração verde mais escuro na face ventral podendo algumas vezes apresentar manchas amarelas. O caule mostrase nitidamente estriado no sentido longitudinal.

Sua seç̧ão transversal evidencia a presença de fistula. 


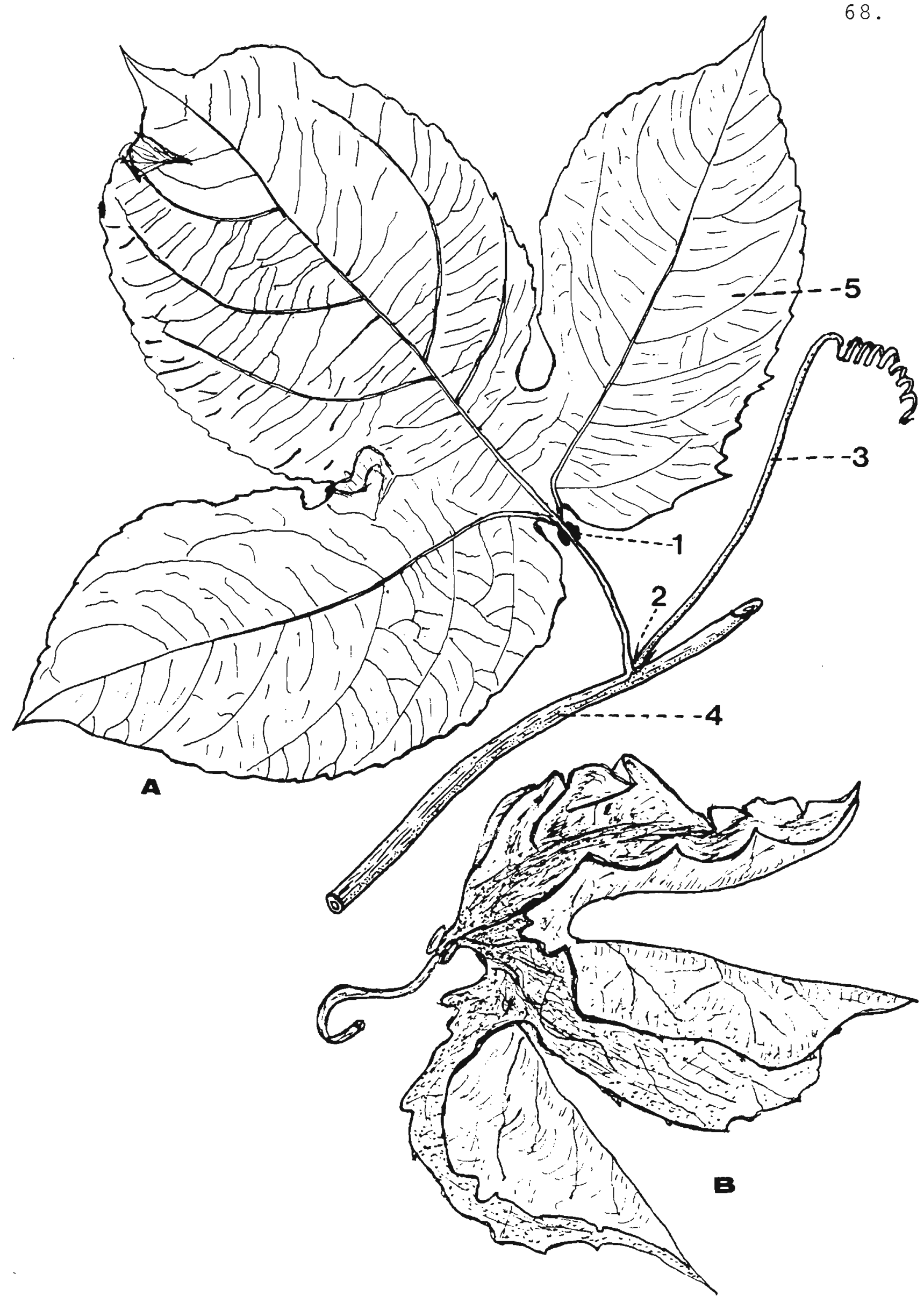

FIGURA 16 - Passiflora edulis Sims. - A-Fragmento da parte aérea: 1-glândula; 2-estīpula; 3-gavinha; 4caule; 5-làmina foliar;-B- Folha como aparece na droga. 


\section{Descrição microscōpica}

Secções transversais das folhas ao nỉvel do terço médio inferior apresentam estrutura heterogênea e assimétrica. A Fig. 17-B, mostra desenho desta re gião. A epiderme superior (Fig. 17B-e.s.) è formada por cēlulas de contorno aproximadamente retangular alongadas no sentido periclinal. O tamanho de suas cēlulas é varíavel. o parēnquima paliçādico (Fig. 17-B-p.p.) é representado por uma única fileira celular. Este parēnquima corresponde a aproximadamente um terço da espessura do limbo. Suas cé 1 ulas possuem comprimento aproximadamente igual a cinco ve zes a largura. O parēnquima lacunoso (Fig. 17-B-p.1.) è bem desenvolvido, sendo constituido de seis a dez fileiras de cēlulas. Feixes vasculares secundārios (Fig. 17-B-f.v.) podem ser observados nesta região, os quais apresentam-se en volvidos por bainha parenquimātica. Cristais estelares de oxalato de cálcio podem ser observados em todo o mesofilo, especialmente na região do parénquima lacunoso. A epider me inferior apresenta-se representada por células irregula res na forma e no tamanho. Estōmatos podem ser vistos nes ta região.

A epiderme superior mostrada em visão paradērmica na Fig. 17-A estä representada por cēlulas de contorno aproximadamente poligonal. A epiderme inferior (Fig. 17-C) por sua vez exibe cēlulas de contorno sinuoso. Nesta região podem ser observados estómatos providos de duas a três células paraestomatais. 
70.

A
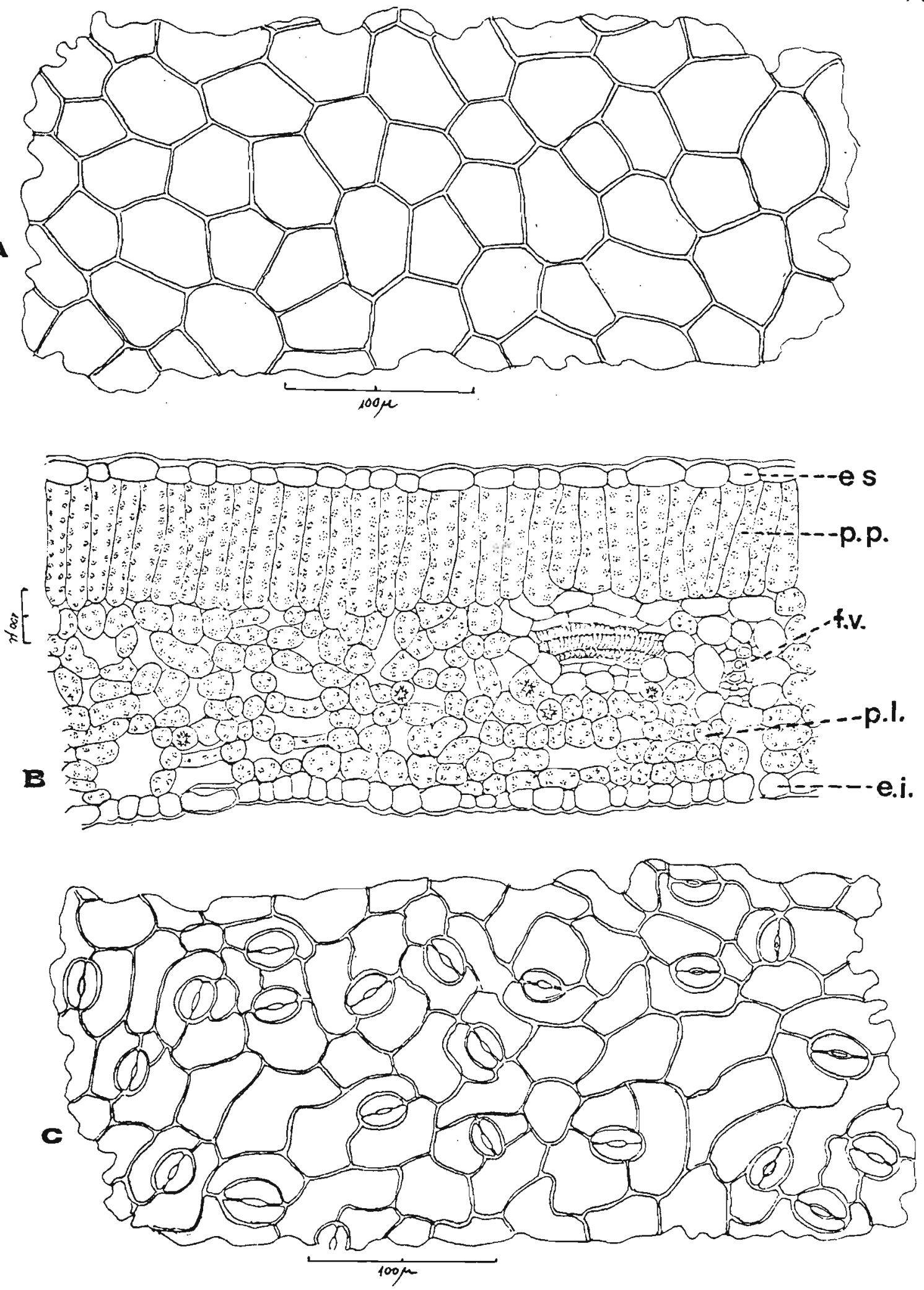

FIGURA 17 - Passiflora edul is Sims.: A-Epiderme superior da folha vista de face. B- Seç̧ão transversal da fó 1 ha: e.s.-epiderme superior; p.p.-parēnquima paliçādico; p.1.-parênquima lacunoso; f.f.- feixe vascular; d-drusa; e.i.-epiderme inferior. C-ep $\underline{i}$ derme inferior vista de face. 
A Fig. 18 apresenta desenho esquemāt co de secção transversal ao nỉvel da nervura mediana na re gião do terço médio inferior da folha. A presença de pểos tectores simples é notada na epiderme que recobre a região da carena. Abaixo das epidermes observa-se a presença de colênquima bem desenvolvido. Segue-se região do parénquima fundamental que envolve quatro a cinco feixes vasculares do tipo colateral dispostos em cỉrculo.

A Fig. 19-A mostra detalhe da região careniforme localizada na região da nervura mediana do lado da epiderme adaxial. Pélos tectores simples cōnicos po dem ser vistos sobre a epiderme. Colēnquima āngular bem desenvolvido pode ser observado contendo drusas.

A Fig. 19-B representa feixe vascular do tipo colateral localizado na região central da nervura mediana. Observa-se a. presença do xilema com os vasos dis postos em fileiras. A região cambial é visivel. Nota-se, ainda, a presença de grande quantidade de drusas do parēnquima floemático.

A Fig. 20-A, B e C mostra secções trang versais do peciolo, respectivamente, ao nivel de sua base, região mediana e āpice. Observa-se nas três estruturas a presença de colēnquima bem desenvolvido. Os feixes vasculares encontram-se distribuídos em dois conjuntos. o primeiro deles é representado por feixes dispostos em círculo; - segundo, por dois feixes dispostos logo abaixo da epider me adaxial um em cada ala formada pela presença da canaleta existente no peciolo. 


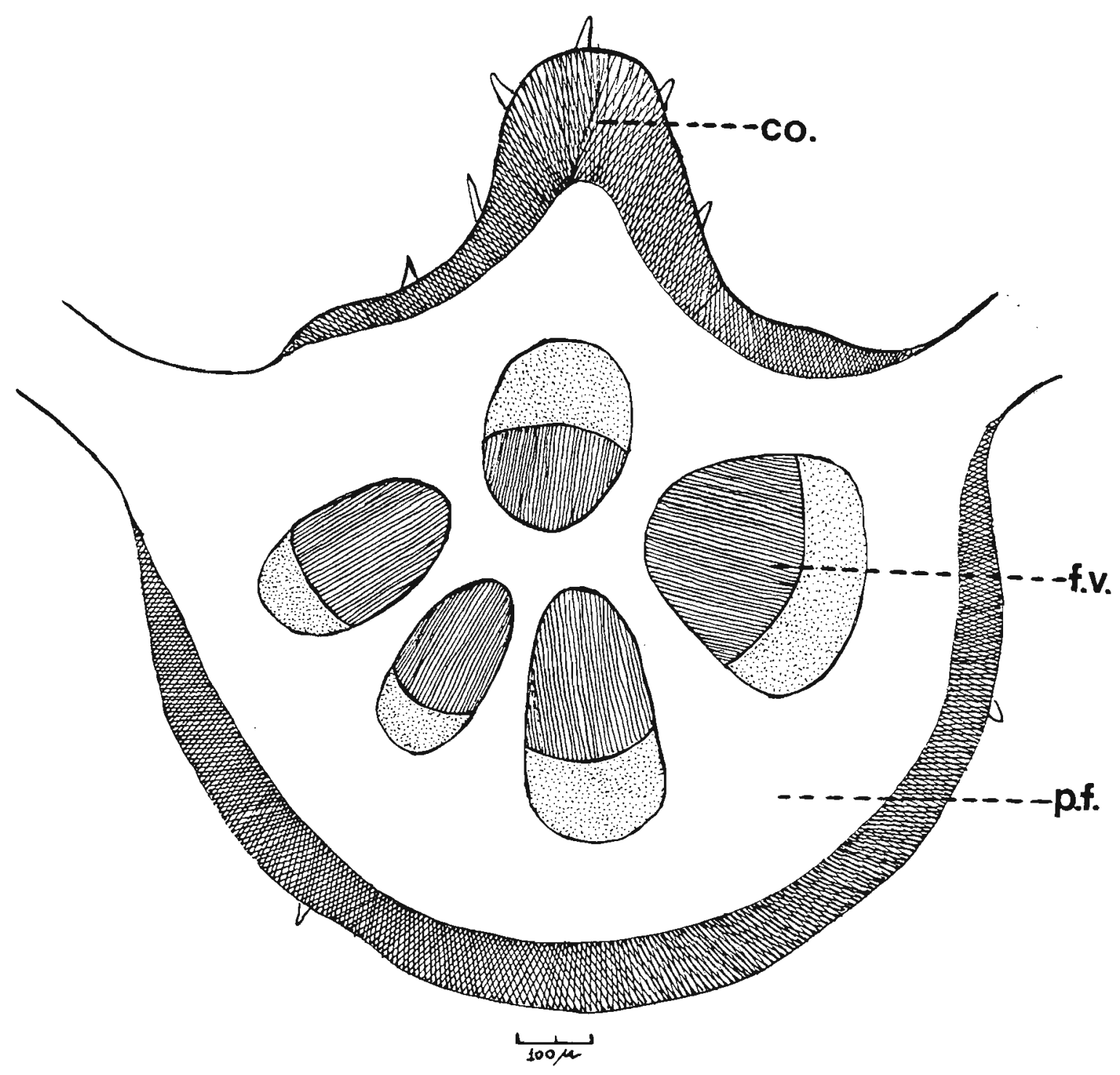

FIGURA 18 - Passiflora edulis Sims.: Desenho esquemático da região da nervura principal ou nĩvel do terço médio inferior do 1 imbo foliar: co-- colēnquima; f.v.-feixe-vascular; p.f.-parēnquima fundamenta 1 . 

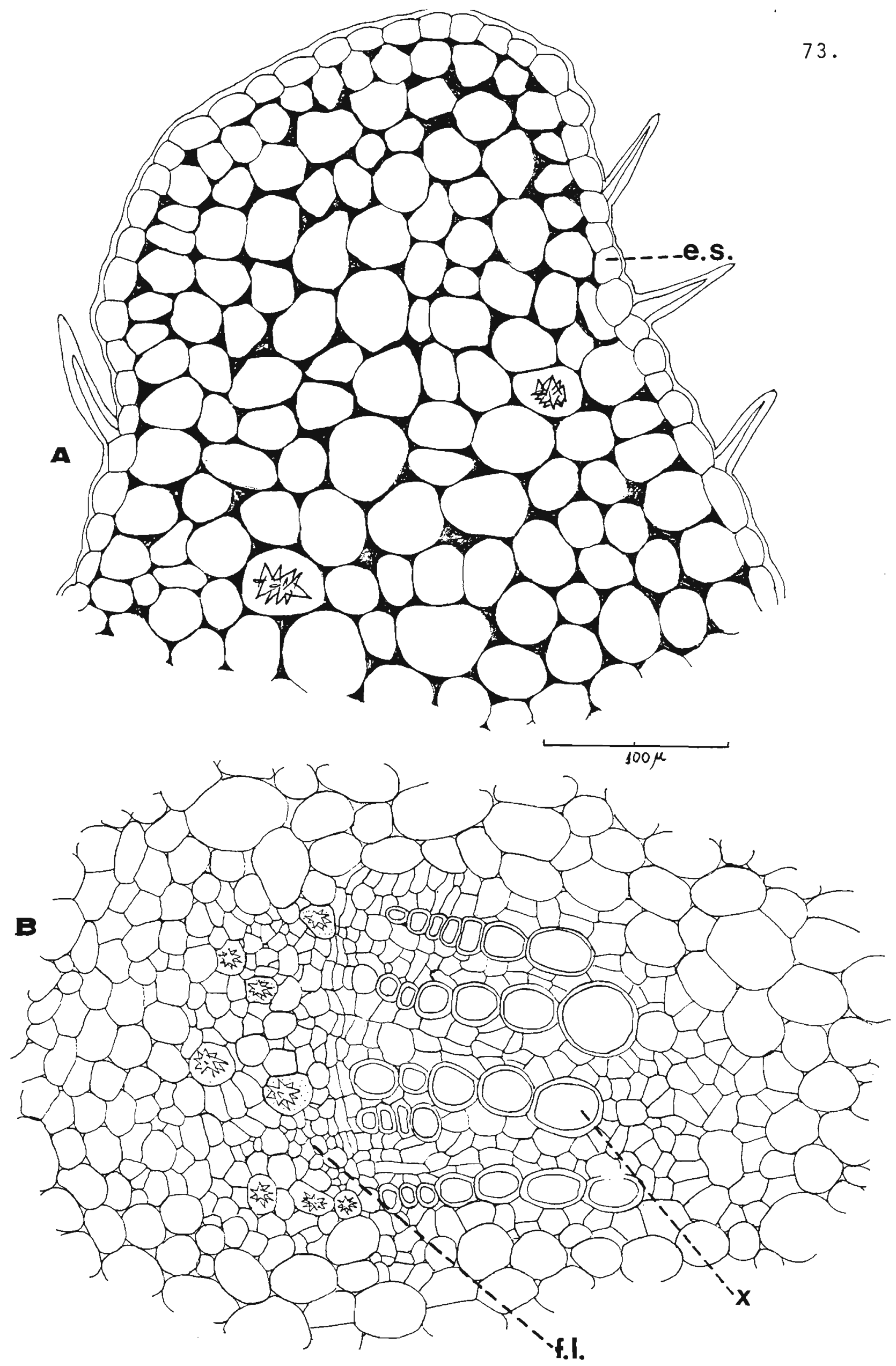

FIGURA 19 - Passiflora edulis Sims.: Secção transversal da folha (detalhes): A- região da carena; e.s.-epi derme superior; co.-colênquima: B- região do feí xe vascular; x-xilema; fl.-floema. 


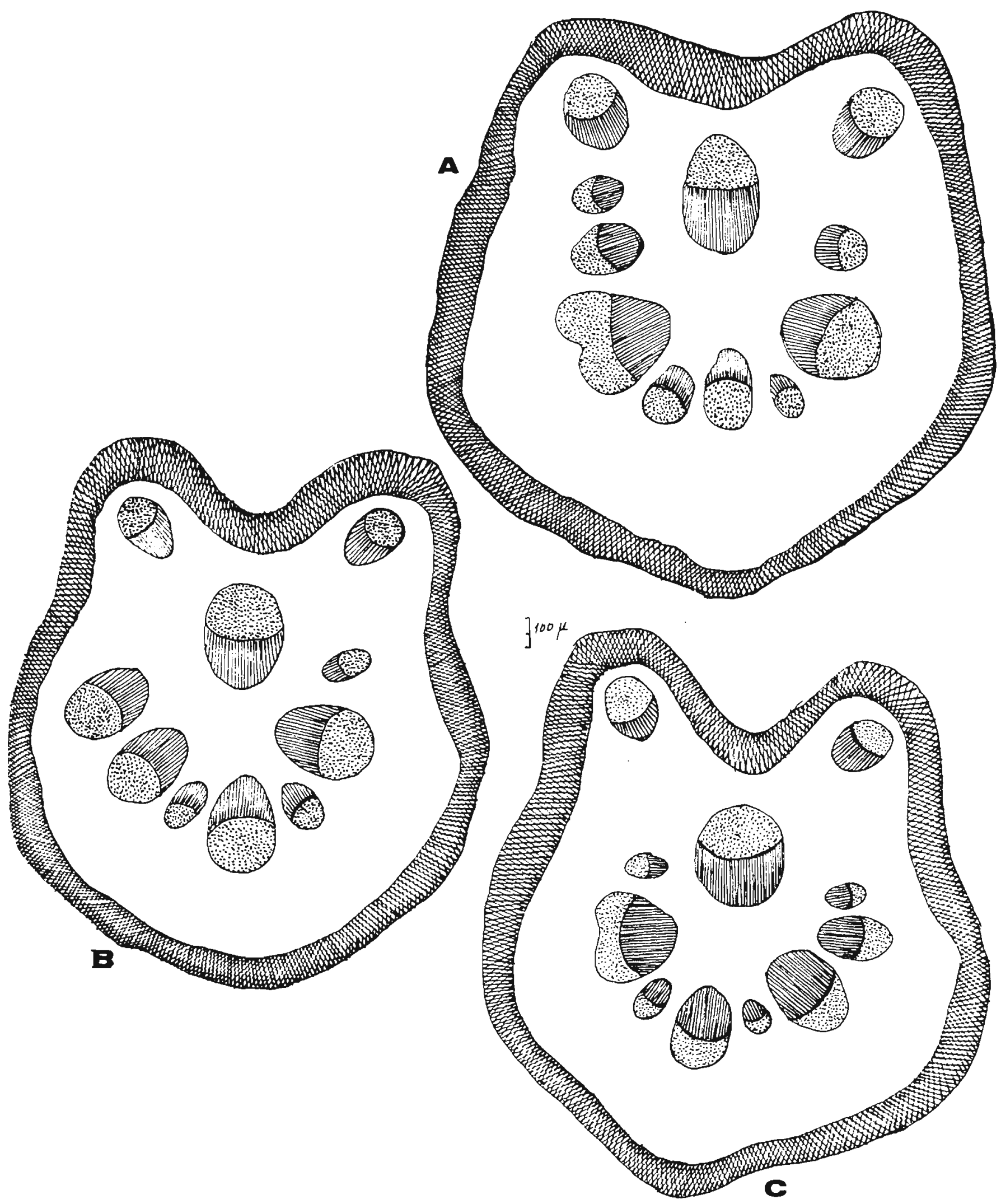

FIGURA 20 - Passiflora eduTis Sims: : Secções transversais do peciolo: A- Região prōxima da inserção no caule; B- Região mediana; C- Região próxima da inserção no limbo foliar. 
A Fig. 21 , representa secção transver sal do caule efetuada próximo do broto apical. Nela pode ser observada a forma arredondada da secção caulinar, bem como a presença de colēnquima em toda a região sub-epidērmica. Os feixes vasculares são do tipo colateral e achamse dispostos em um circulo, sendo portanto a estutura do tipo eustēlica.

A Fig. 22 representa detalhe da estrutura caulinar. Nela se observa a presença de epiderme constituída de cēlulas irregulares na forma e no tamanho. Abaixo da epiderme observa-se a presença de região colenquimática provida de cēlulas com espessamento nos cantos (Fig. 22-Co.). Observa-se, ainda, o início da formação de sūber. O parénquima cortical é pouco desenvolvido e a endoderme não é característica. O periciclo (Fig. 22-p.f.), mostra-se descontínuo e fibroso assumindo formação de calo ta que protege o feixe vascular. A região cambial é bem visĩvel, notando-se a presença de drusas no parēnquima floe mātico (Fig. 22-f.1.). O xilema primärio aparece disposto em fileiras radiais, sendo representado por um ou dois ele mentos de protoxilema e por elementos de metaxilema. Os va sos do xilema secundārio possue tendéncia a se alinharem radialmente. Na região xilemätica observa-se com frequência a presença de células parenquimáticas de tamanho um pouco maior e providas de conteúdo granuloso escuro. 0 pa rēnquima medular é bem desenvolvido, podendo ser observada a presença de cēlulas providas de parede espessada junto à região mais interna dos feixes vasculares. 


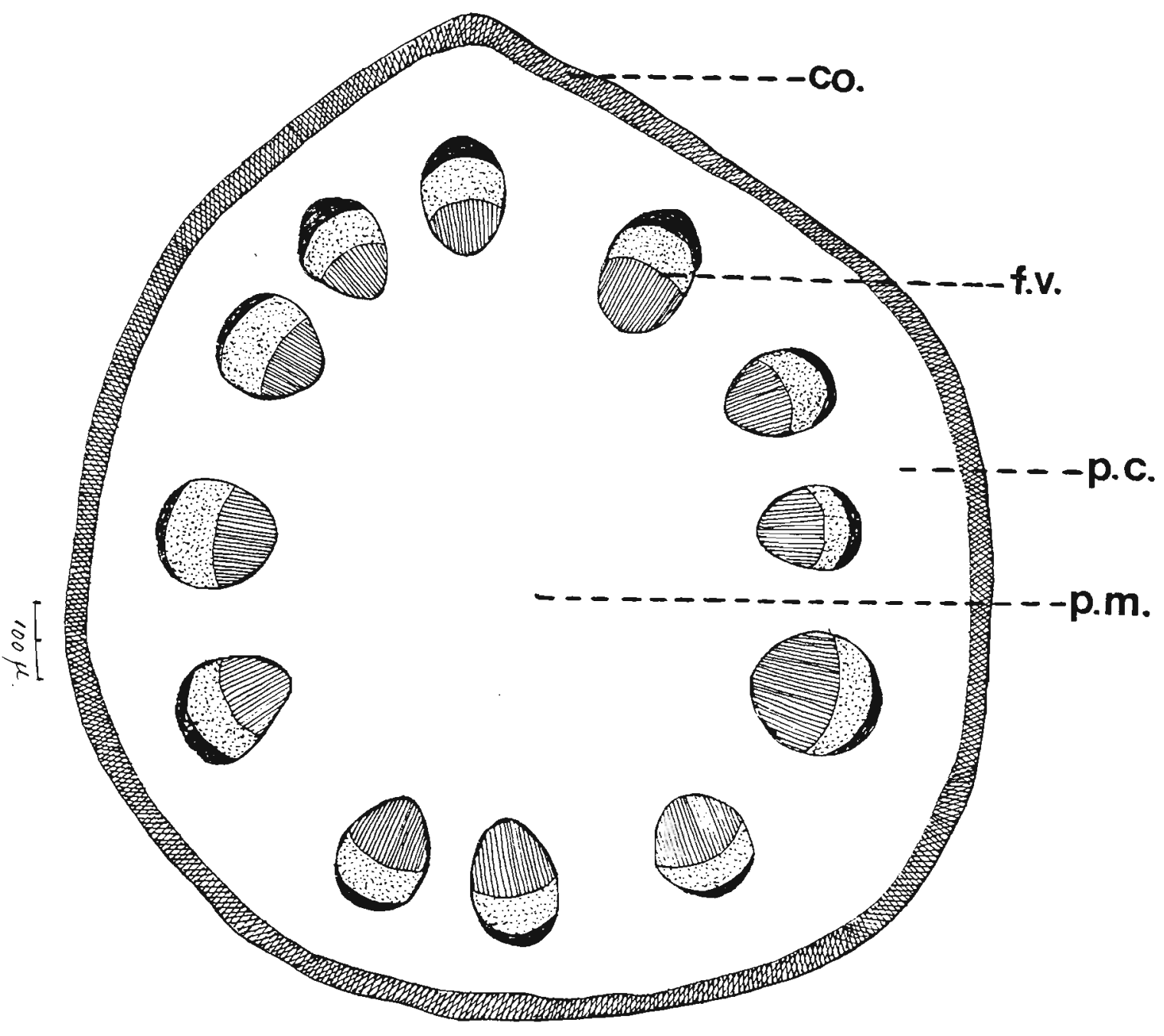

FIGURA 21 - Passiflora edulis Sims.: Desenho esquemático de secção transversal do caule: co.-colénquima; f.v. feixe vascular; p.c.-parēnquima cortical; p.m.medula. 


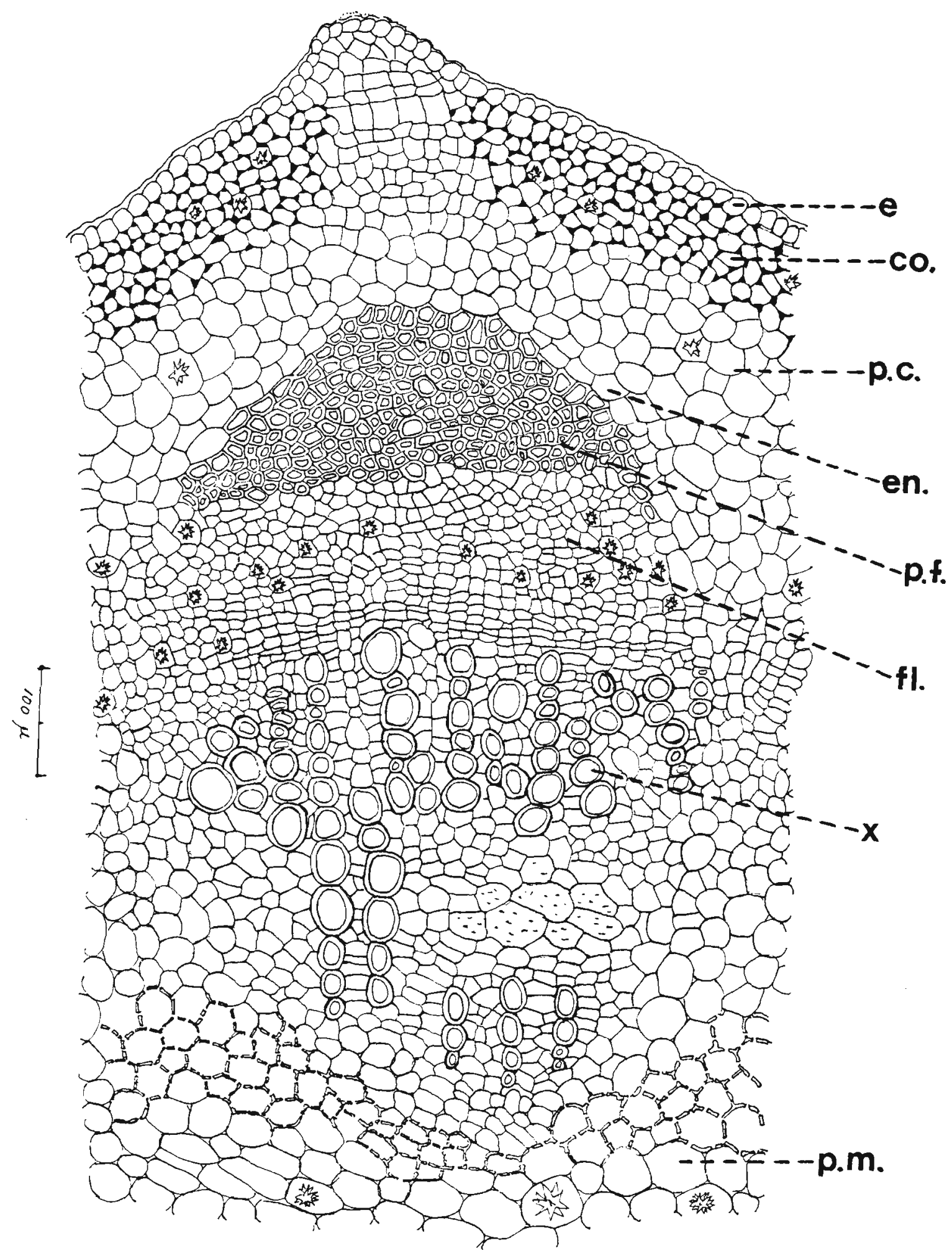

FIGURA 22 - Passiflora edulis Sims.: Secção transversal do caule: e-epiderme; co-colênquima; p.c.- parēnquima cortical; en.-endoderme; p.f.- periciclo fibroso; f1.-floema; x-xilema; pm.-medula. 


\section{1 .4 - Passiflora incarnata $L$.}

\section{Caracterização macroscōpica}

As folhas do vegetal são simples, 1 igeiramente pubescentes, trilobadas, providas de estípulas setāceas, as quais medem de 2 a $3 \mathrm{~mm}$ de comprimento e caracterizam-se por ser decĩduas. 01 imbo foliar mede de 6 a $15 \mathrm{~cm}$ de comprimento no sentido da nervura mediana, 5 a $12 \mathrm{~cm}$, ao longo das nervuras 1 aterais e 7 a $15 \mathrm{~cm}$ entre os ápices dos lobos laterais. Estes possuem contorno ovallanceolado ou oval oblongo sendo providos de ápice acumina do e margem serrilhada. A base da folha é tipicamente cuneata e sua consistēncia é membranācea. Os peciolos possuem até $8 \mathrm{~cm}$ de comprimento e apresentam em sua região ap $\underline{j}$ cal duas glāndulas suborbiculares e sēsseis. Gavinhas podem ser observadas partindo das axilas foliares (Fig. 23).

As folhas apresentam trēs nervuras principais, uma mediana e duas laterais, das quais partem nervuras secundārias que formam com as nervuras principais àngulos de aproximadamente $45^{\circ}$.

o caule é cilīndrico, ligeiramente estriado, de coloração castanha nas partes mais velhas e arroxeada em partes terminais.

A droga obtida a partir das partes aéreas do vegetal é representada por folhas misturadas a pedaços de caule. As folhas apresentam-se amarrotadas e 
79.

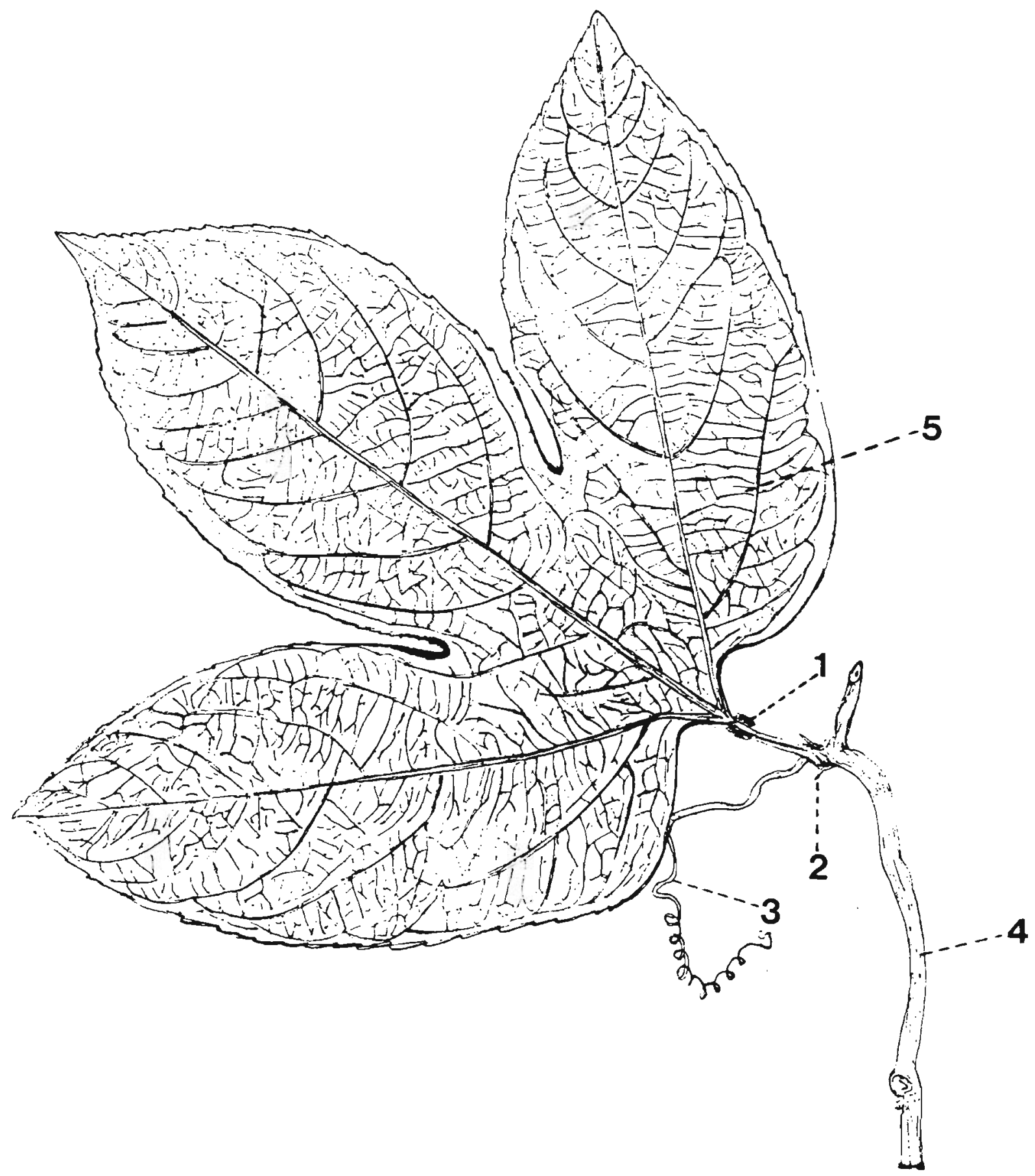

FIGURA 23 - Passiflora incarnata L.: Fragmento de parte aérea: 1-giāndula; 2- estīpula; 3-gavinha; 4-caule; 5- 1ãmina foliar. 
com frequência apresentam-se presas a fragmentos de caule. Gavinhas podem ser observadas. Os fragmentos de caule pos suem aspecto estriado e com frequência são providos de fís tula.

\section{Caracterização microscōpica}

A secção transversal da folha, ao ní vel do terço mēdio inferior apresenta estrutura heterogēnea e assimëtrica, representada na Figura 24-A. A epiderme superior é constituída por células de contorno arredondado e irregulares no tamanho. E recoberta por cutícula medianamente espessa e mostra a presença de pêlos tectores cōnicos providos de atē cinco cēlulas, geralmente duas, dispostas em uma ūnica sērie. 0 parēnquima paliçādico cons titui-se de uma camada de cēlulas cujo comprimento representa quase a metade da espessura do mesofilo. 0 parénqui ma lacunoso é denso sendo composto por quatro a seis camadas celulares. Feixes vasculares secundārios podem ser ob servados, sempre providos de bainha parenquimática, que nos vasos mais desenvolvidos se relaciona com a epiderme superior. As caracteristicas da epiderme inferior se asseme1 ham às da superior, diferindo desta pelo nümero bem mais elevado de estōmatos e pēios tector.s.

A Fig. 25-A, representa visão paradérmica da epiderme inferior. Nela pode ser observada a presença de cēlulas de contorno sinuoso e estómatos conten do três a cinco células paraestomatais alēm de pêlos unisseriados constituídos por 1 a 5 células. 
81.
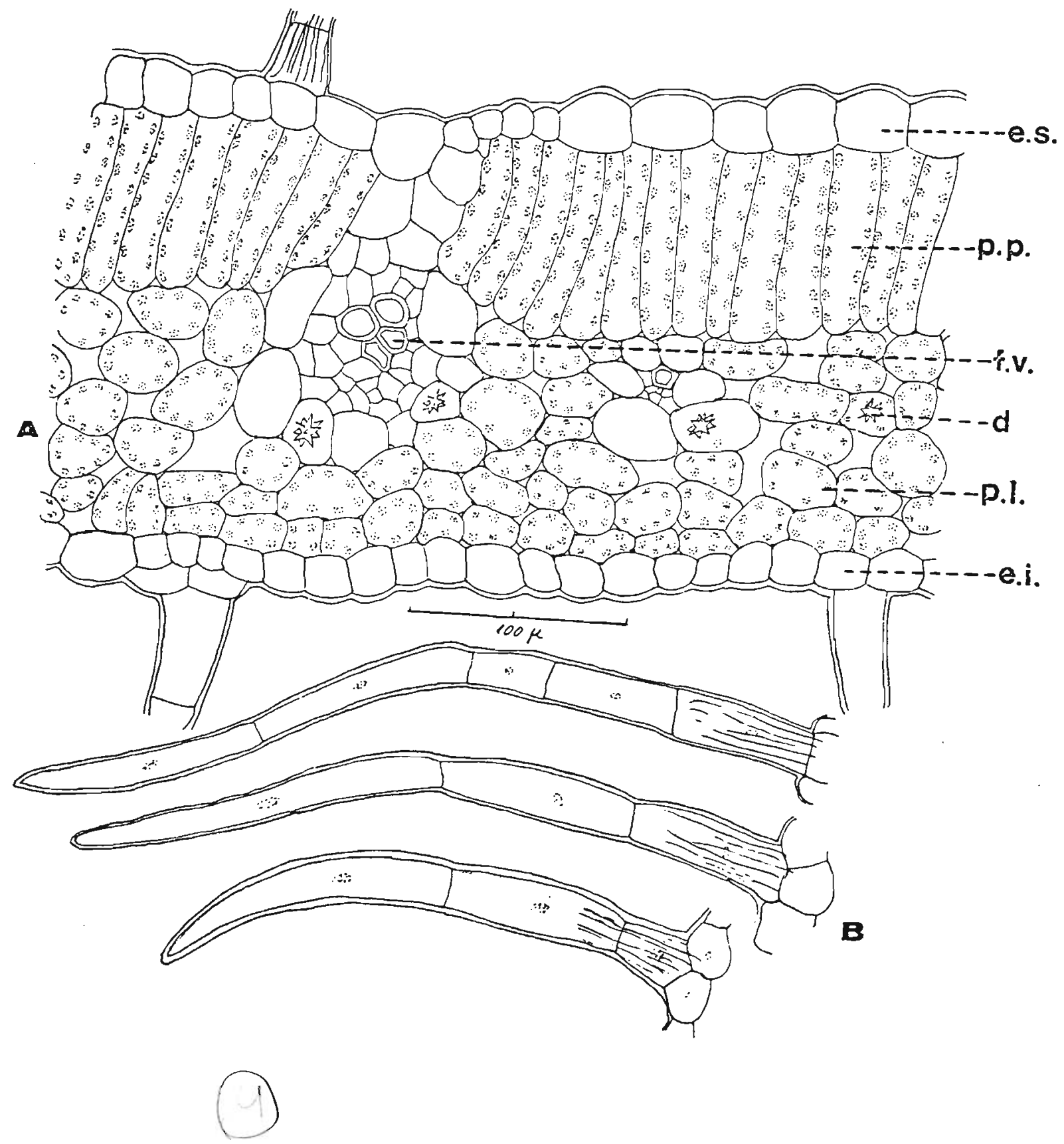

FIGURA 24 - Passiflora incarnata L.: A- Secção transversal da folha; e.s.-epiderme superior; p.p.- parēnquima paliçādico; f.v.-feixe vascular; p.l.-parēnquima 1 a cunoso; d-drusa; e.i-epiderme inferior. B-Pélos tectores. 

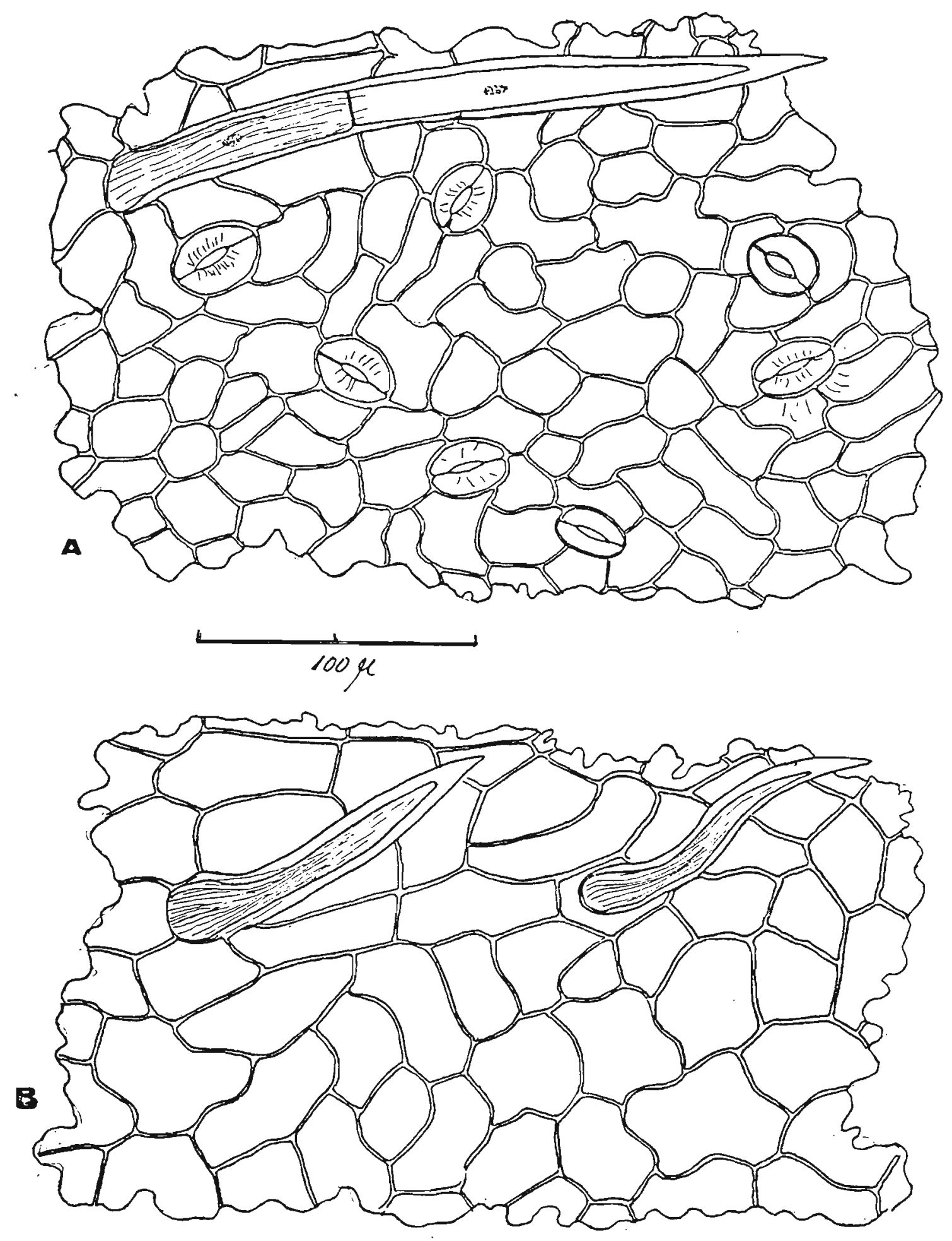

FIGURA 25 - Passiflora incarnata L.: A- Epiderme inferior da folha vista de face; B-Epiderme superior da foIha vista de face. 
A Fig. 25-B mostra epiderme superior em corte paradérmico. Nesta região observa-se a presença de células de contorno sinuoso um pouco maiores do que as da epiderme inferior, e onde, frequentemente, os pēlos tectores são mais curtos e constituĩdos por menor nümero de cēlulas.

A Fig. 26 representa seç̧ão transver sal da nervura mediana ao nīvel do terço médio inferior da folha adulta. Tanto a epiderme superior como a inferior a presentam-se providas de pēlos tectores. As cēlulas epidér micas apresentam-se, frequentemente, alongadas no sentido periclinal na epiderme superior e anticlinal na inferior. A baixo das duas epidermes nota-se a presença de colénquima com as cēlulas contendo espessamento nos àngulos. 0 parén quima fundamental é bem desenvolvido e envolve um conjunto de feixes vasculares dispostos em círculos. Cristais este lares de oxalato de cālcio estão distribuĩdos por toda a re gião parenquimática.

As Figs. 27-A, B e C representam secções transversais do pecĩolo ao nīvel da base, meio e āpice, respectivamente. Podem ser observados numerosos pêtos tectores sobre a epiderme e abaixo dela um tecido colenqui mätico continuo. Os feixes vasculares estão distribuídos em dois conjuntos: um localizado na região central, com os feixes dispostos em circulo, e outro logo abaixo da epider me adaxial, com 4 feixes localizados 2 de cadalado (Fig. 27) .

A Fig. 28 representa secção transver sal de caule jovem cuja forma mostra-se arredondada aproxi 
84.

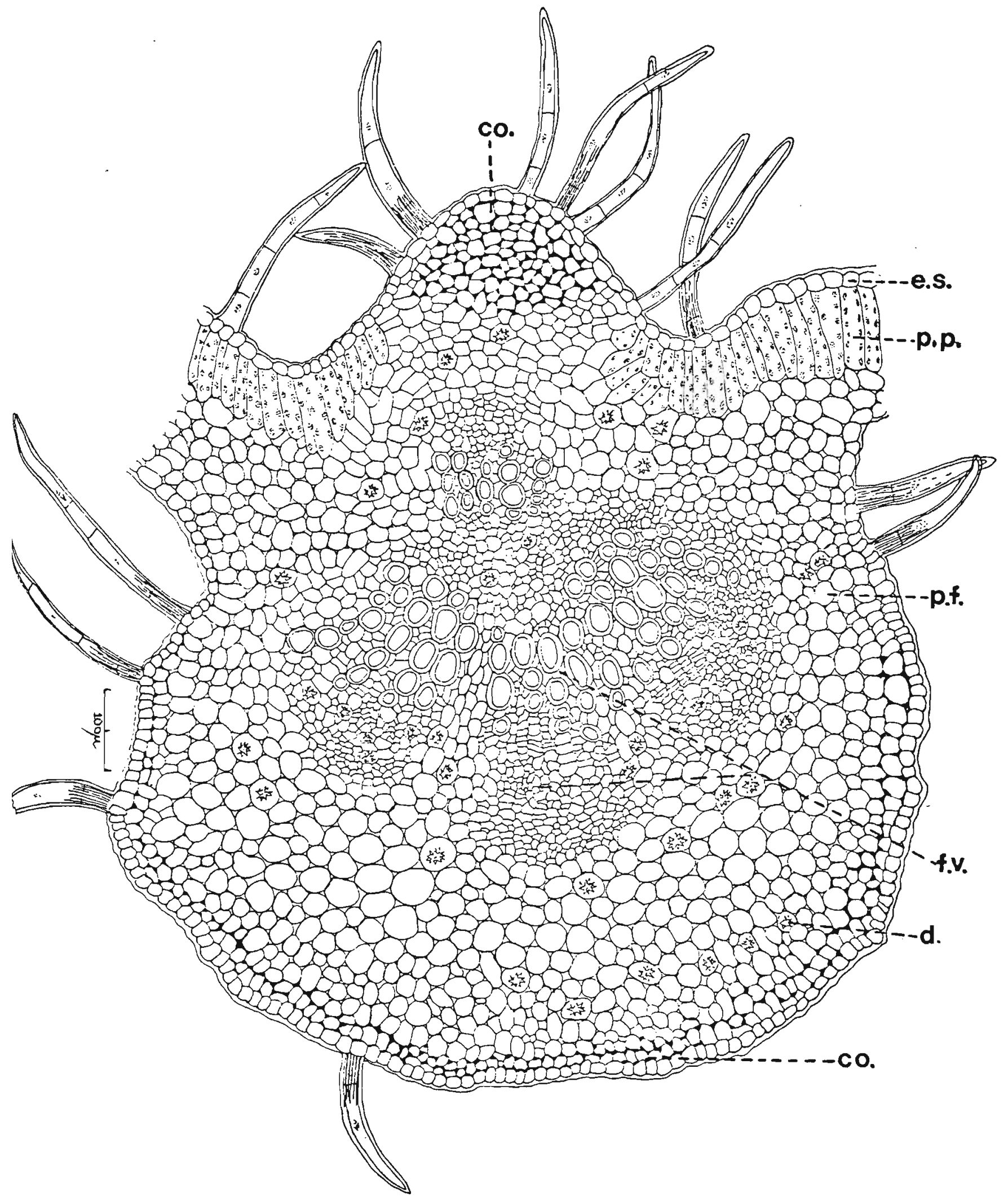

FIGURA 26 - Passiflora incarnata L.: Secção transversal da nervura mediana da folha ao nivel do terço médio inferior; es.-epiderme superior; p.p.-parēnqui ma paliçádico; co.-colēnquima; p.f.-parēnquima fun damental; f.v-feixe vascular; d-drusa. 


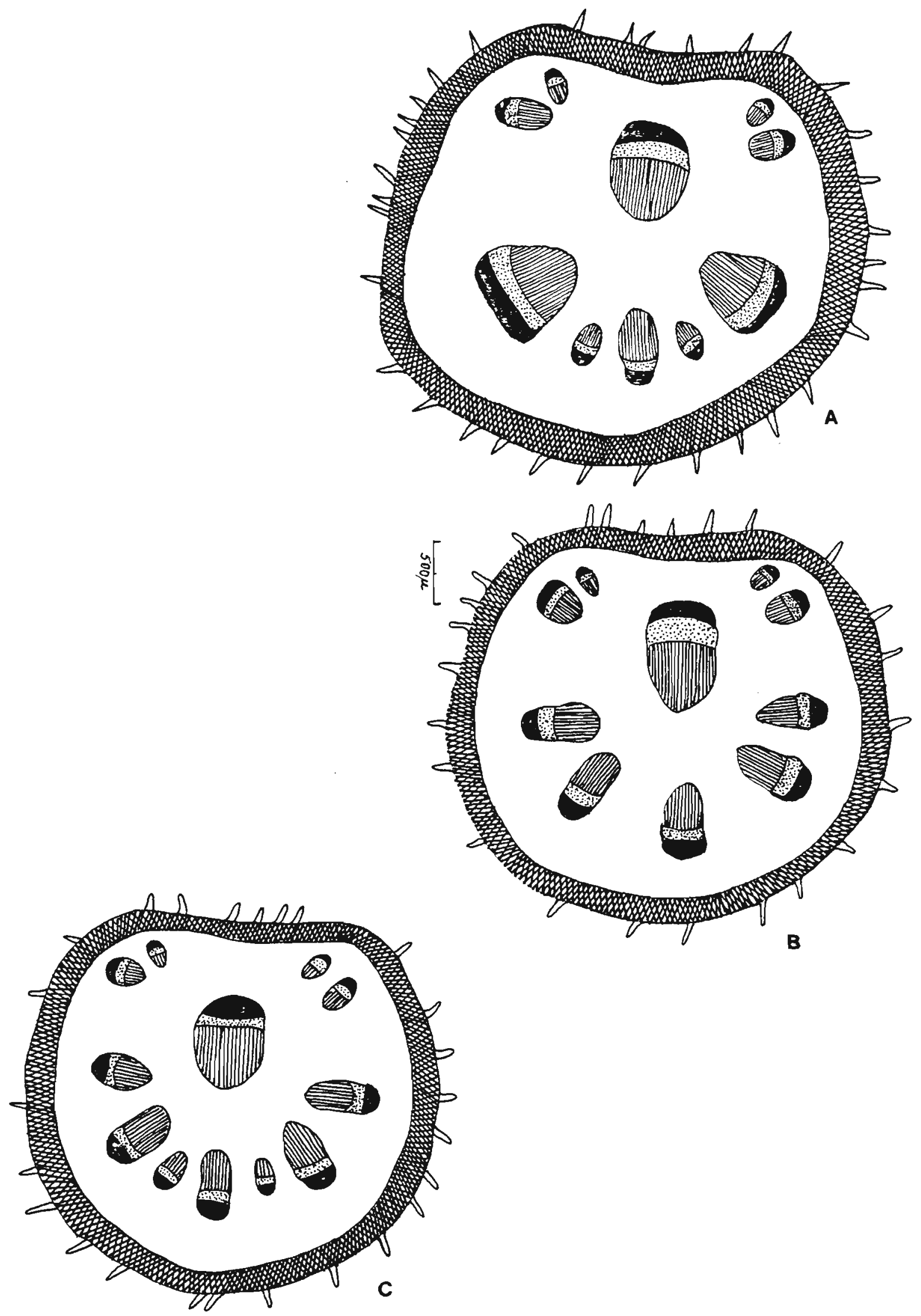

FIGURA 27 - Passiflora incarnata L.: Secçõs transversais dos pecĩolos: A- Região próxima à inserção no caule; B- Região mediana; C- Região prōxima à inserção na làmina foliar. 


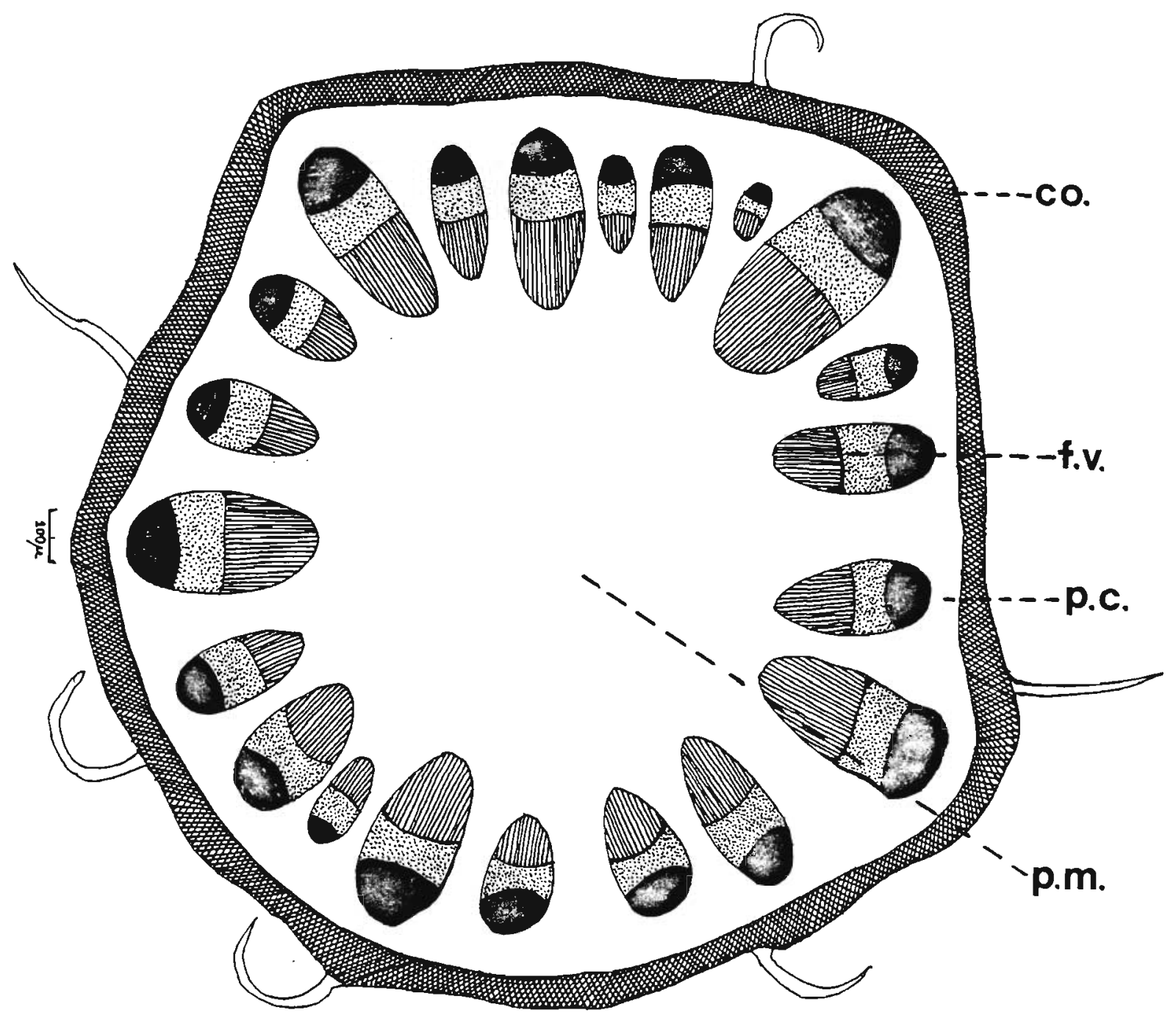

FIGURA 28 - Passiflora incarnata L. Desenho esquemātico da seção transversal do caule. co.-colēnquima; $f$. v.-feixe vascular; p.c.-parênquima cortical; p. m. - medula. 
mando-se da pentangular. A estrutura é eustēlica. A epiderme é provida de pēlos tectores e abaixo dela localizase uma camada continua de tecido colenquimático.

Um detalhe da seç̧ão transversal do caule é mostrado na Fig. 29. A epiderme ē representadapor cēlulas irregulares na forma e no tamanho, providas de pare des espessadas. Apresenta pêlos tectores constituídos, ge ralmente, por uma atē trēs cēlulas dispostas em sērie, e cutícula que reveste todo o tecido. A região colenquimāti ca é representada por duas a quatro fileiras de células com espessamento nos cantos. Observa-se um parēnquima cortical pouco desenvolvido, endoderme não tĩpica e um periciclo fibroso descontínuo em forma de calotas. 0 xilema pri mārio apresenta-se em filas radiais, sendo constituīdo de um ou dois elementos de protoxilema e outros de metaxilema; - xilema secundārio apresenta com frequência um vaso isola do de grande abertura, envolvido por tecido parenquimático. A região floemātica é bem desenvolvida. Drusas podem ser observadas espalhadas por toda a estrutura sendo mais frequentes no parénquima floemático e raras no tecido epidērmico. Em toda a região parenquimātica são encontrados grãos de amilo, especialmente no parénquima cortical, na endoder me e nos raios medulares. 


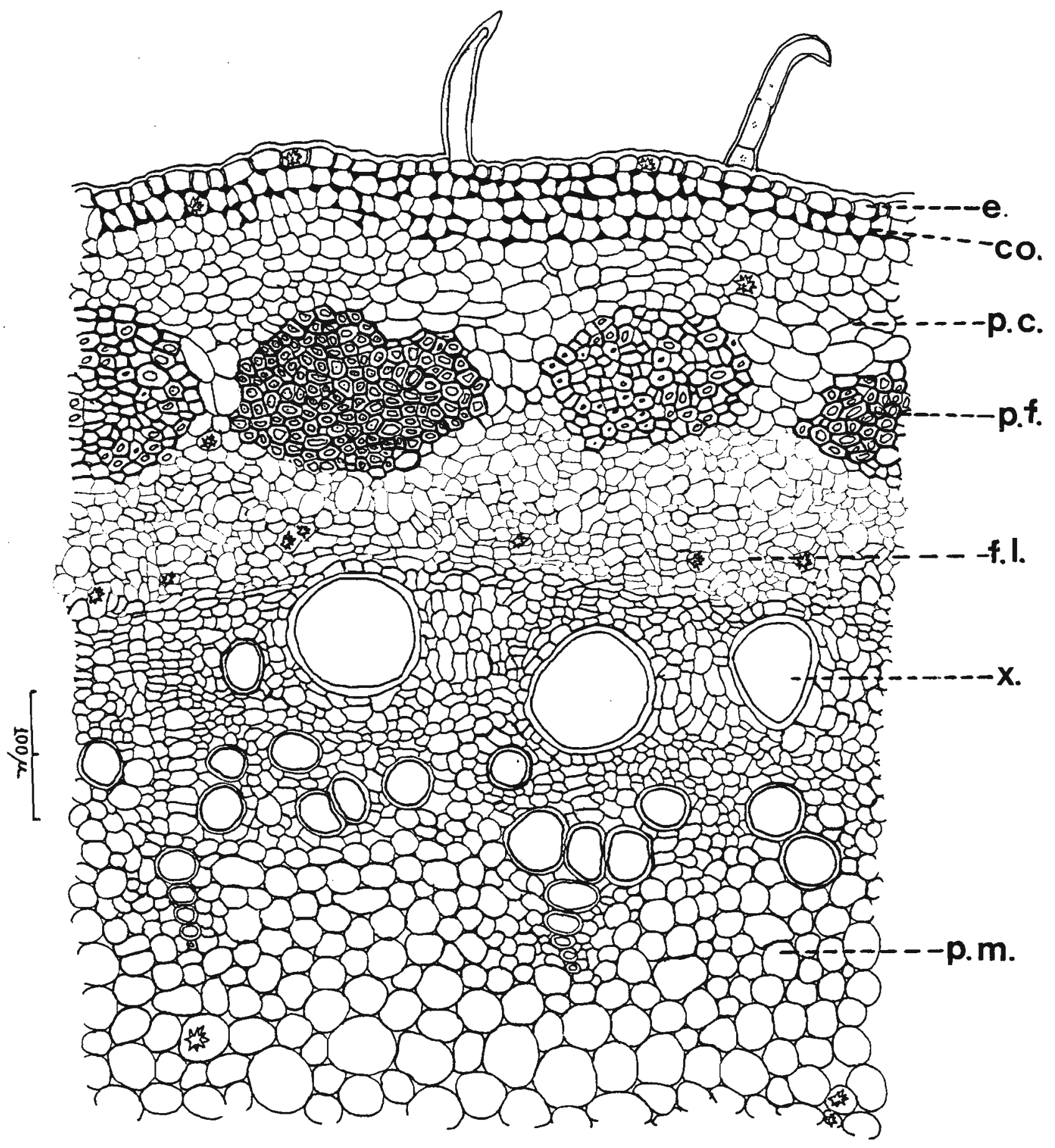

FIGURA 29 - Passiflora incarnata L.: Secção transversal do caute: e-epiderme; ca-colēnquima; p.c-parēnquima cortical; p.f-periciclo fibroso; fl.-floema; $x$-xilema; pm-parēnquima medular. 


\subsection{1 - Anālise Cromatogrāfica da Fração Flavonoí- dica dos Extratos Fluídos das Diversas Es- pécies de Passiflora L.}

Os perfis cromatogräficos das frações flavonóidicas dos extratos fluidos dos maracujās obti dos a partir da cromatografia em camada delgada conforme o item 3.2 .2 .2 , acham-se registrados na fotografia seguinte:
A
$a$
E
V Ik
0
lo. MP

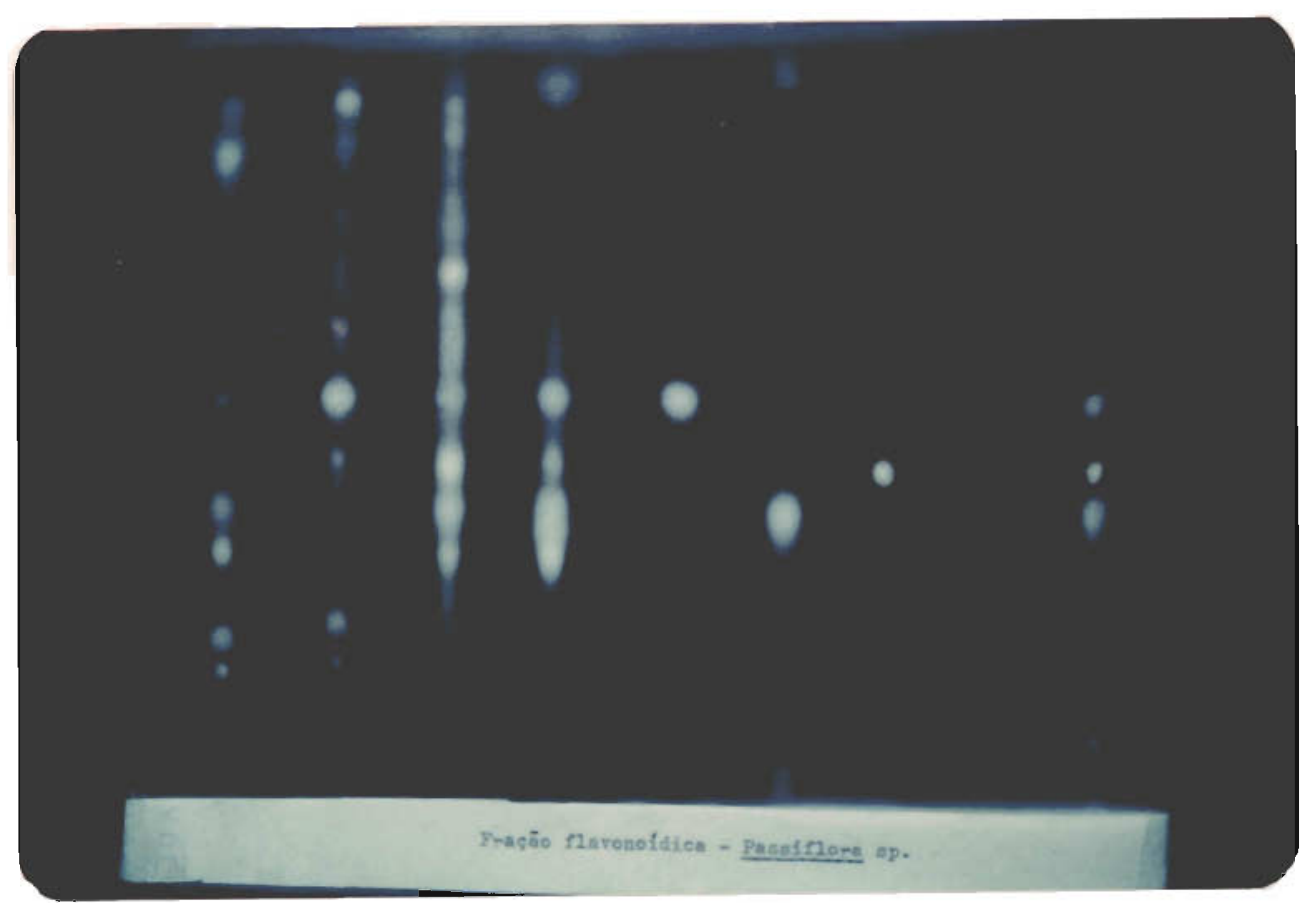

FIGURA 30 - Cromatograma das frações flavonoídicas dos ex tratos de Passiflora L. Amostras: $A=$ P.alata L.; $Q=\underline{P}$.quadrangularis $L . ; E=\underline{P}$.edulis sims.; $I=$ P.incarnata L.. Padröes: V=Vitexina; IV= Isovitexina; $0=$ Orientina; Io= Isoorientina; $M P=$ Mistura de padrões. 
4.2.2 - Anālise Cromatogrāfica em Camada Delgada da Fração Alcaloídica dos Extratos de

\section{Passiflora L.}

Os perfis cromatogrāficos obtidos utị

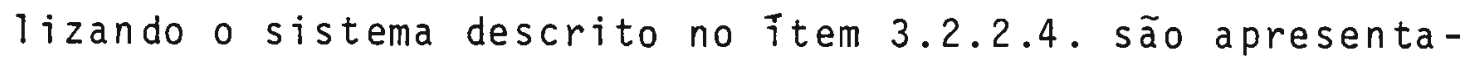
dos na Fig. 31 .
A
Q Mp $\quad H$
$\mathrm{Hi}$

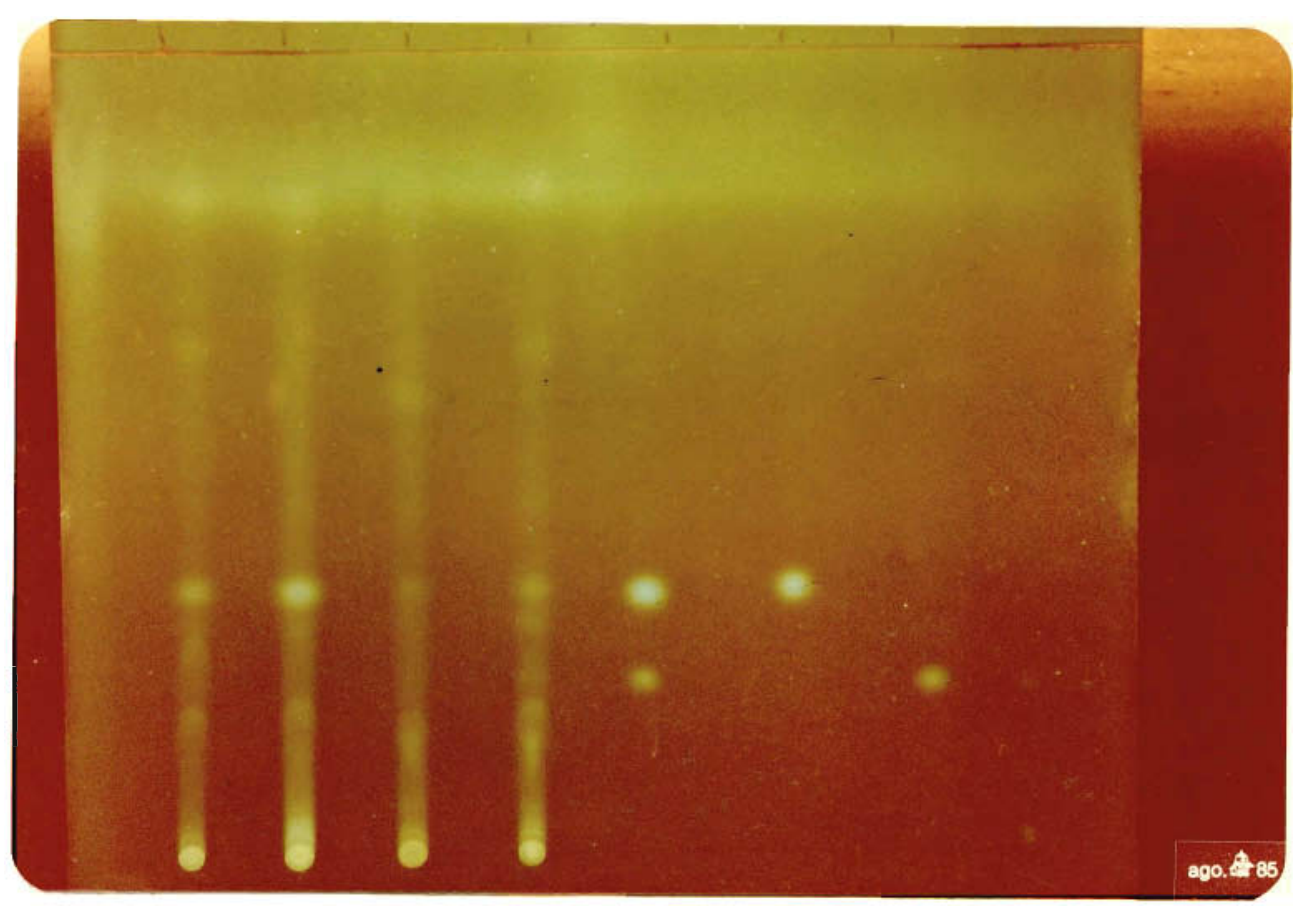

FIGURA 31 - Cromatograma das frações alcaloídicas dos extratos de Passiflora L. Amostras: idem a Figura 30. Padrões: $H a=$ Harmana; $H i=H a r m i n a ; ~ M p=$ Mistura de padrões. 
4.2.3 - Teores Flavonoídico e Alcaloúdico do Extrato Seco de $\underline{\text { P.alata }}$ Dryand.

4.2.3.1 - Determinação dos flavonōides por anāi ise densitométrica.

A curva padrão obtida com orientina segundo as condições do item 3.2.3., ē apresentada na Fig. 32 .

os valores encontrados para os teores de flavonóides totais foram:

a) $45,5 \mu \mathrm{g} / 700 \mathrm{mg}$

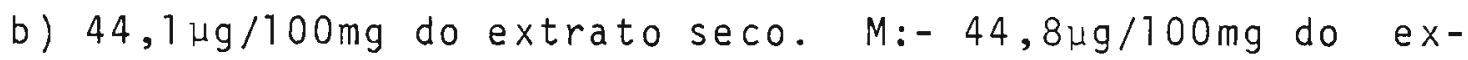
trato seco de $\underline{\text { p. alata }}$ Dryand.

4.2.3.2 - Determinação de alcalóides harmānicos por densitometria em placa cromatogräfica.

A curva padrão construĩda a partir das soluções de harmana conforme o descrito no item 3.2.4. é apresentada na Fig. 33 .

Os valores encontrados para o alca10 i de harmana:

a) $0,075 \mu \mathrm{g} / 100 \mathrm{mg}$

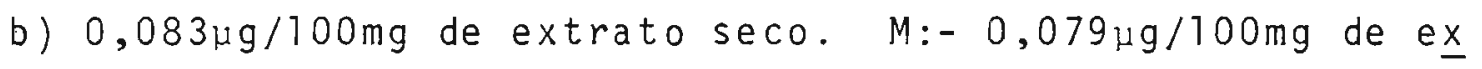
trato seco de $\underline{P}$. alata Dryand. 


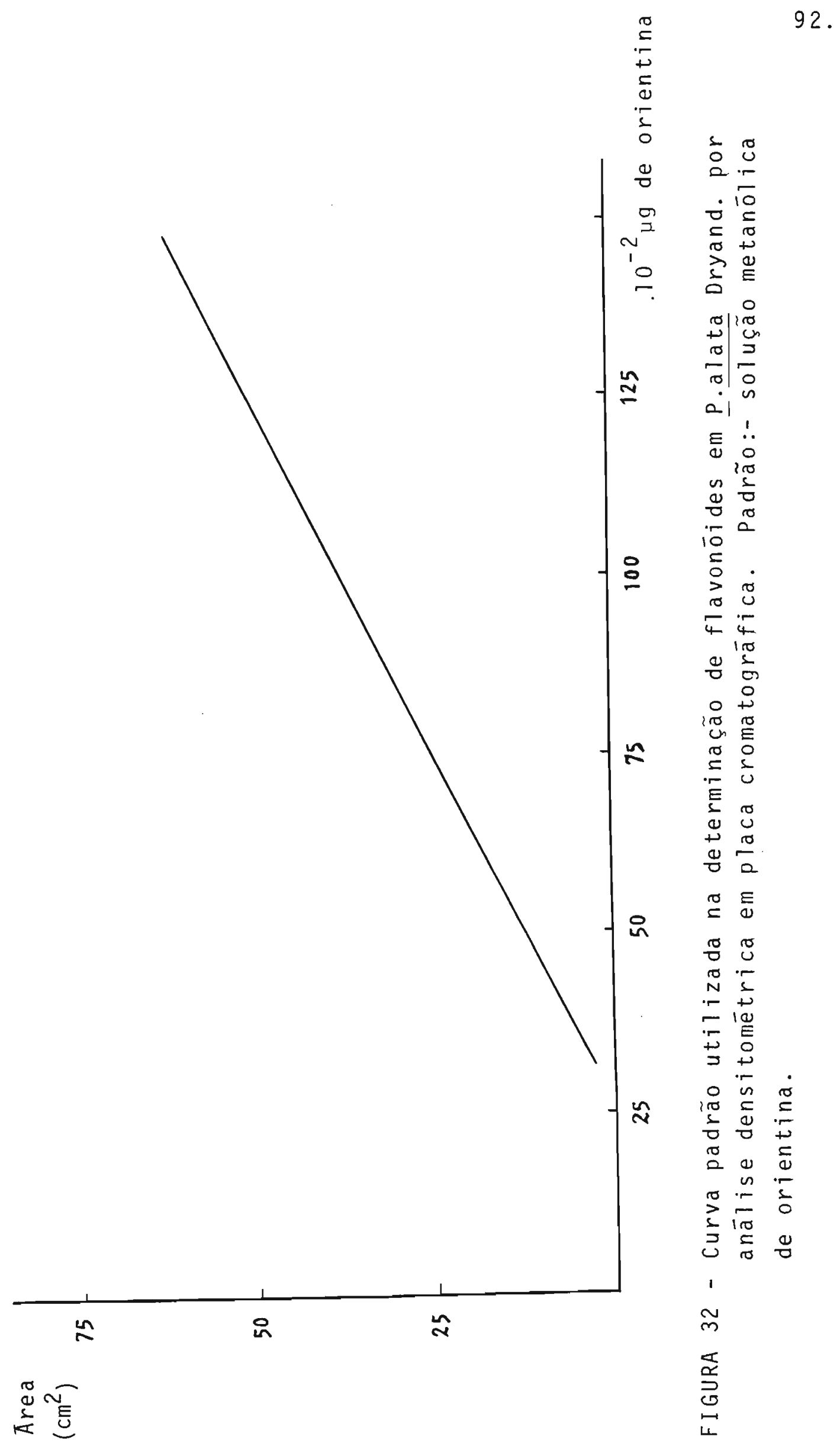


93.

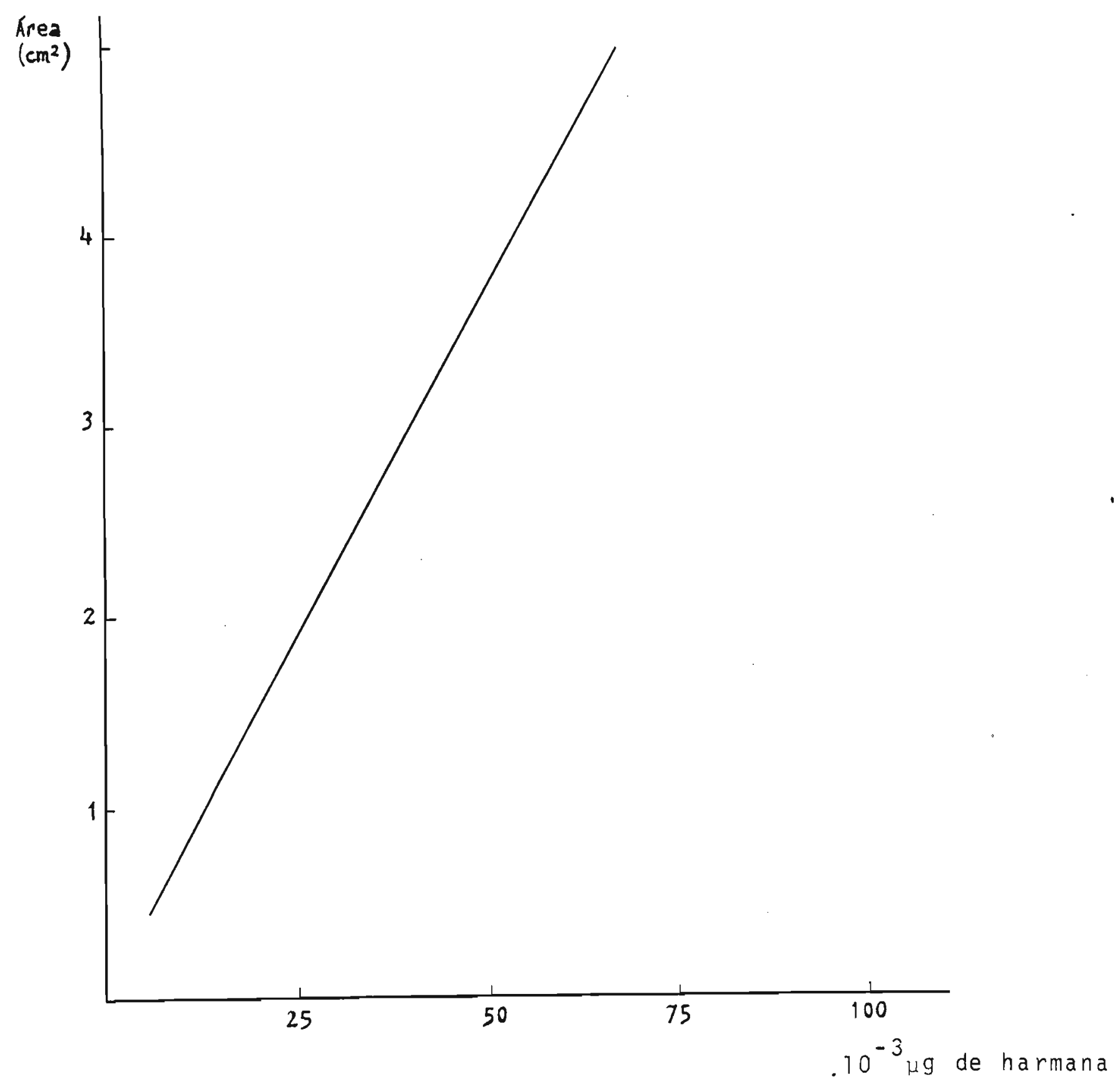

FIGURA 33 - Curva padrão obtida com solução de harmana em metanol, utilizada na anāi ise densitométrica por cromatografia em camada delgada dos alca1óides de Passiflora L. 
Para os alcalóides totais relaciona dos a harmana, e que apresentavam fluorescēncia, os resultados foram:-

a) $0,213 \mu \mathrm{g} / 100 \mathrm{mg}$

b) $0,220 \mu \mathrm{g} / 100 \mathrm{mg}-M:-0,217 \mu \mathrm{g}$ de a $1 \mathrm{ca} 10 \overline{i d e s}$ por $100 \mathrm{mg}$ de extrato seco de $\underline{P}$. alata Dryand.

4.3 - FARMACOLOGIA

4.3.1 - Atividade Farmacológica do Extrato de $\underline{P}$. a 1 ata Dryand.

4.3.1.1 - Tempo de sono induzido pelo pentobarbital.

o pentobarbital è um barbitūrico de rivado da maloniluréia empregado principalmente para induzir o sono. O sono produzido é semelhante ao sono fisioló gico. E considerado depressor de todo o sistema nervoso central e em doses mais elevadas sobre o sistema nervoso autōnomo. São particularmente sensĩveis às suas ações o cōrtex cerebral, a substāncia reticular e, no bulbo, o cen tro respiratōrio, causando depressão respiratōria (67).

Os resultados deste experimento estão representados na TABELA I. Os dados mostram que o ex-

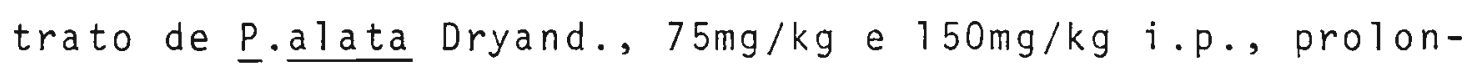
ga o tempo de sono induzido, pelo pentobarbital, com o aumento percentual de $110 \%$ com a dose maior do extrato. 
TABELA I

Efeito do extrato de $\underline{\text { palata }}$ Dryand. no tempo de sono indu zido pelo pentobarbital sódico

\begin{tabular}{lcc}
\hline GRUPOS & $\begin{array}{c}\text { Tempo de sono } \\
(\mathrm{min} .)\end{array}$ & $\begin{array}{c}\text { Aumento } \\
(\%)\end{array}$ \\
\hline Controle - salina & $45,7 \pm 10,0$ & 38 \\
Extrato $(75 \mathrm{mg} / \mathrm{kg})$ & $107,0 \pm 13,0^{*}$ & 110 \\
Extrato $(150 \mathrm{mg} / \mathrm{kg})$ & $139,8 \pm 3,4^{*}$ & \\
\hline
\end{tabular}

* Significante $(p<0,05$, Tukey) em relação ao controle.

- Cada valor representa a média t Erro Padrão obtidos de 10 animais.

- Todos os animais receberam $25 \mathrm{mg} / \mathrm{kg}$ i.p. de pentobarbital sōdico (Nembutal ${ }^{R}$ ) 60 minutos apōs a administração do extrato de P.alata Dryand. 
96.

\section{3 .1 .2 - Convulsão por estricnina}

A estricnina è um estimulante central de ação predominante na medula, aumentando os reflexos medulares e em doses tóxicas provocando convulsões tónicas. Esta droga inibe a ação do mediador inibitōrio dos neurônios. Na falta da inibição causada pelos terminais inibitórios, os efeitos dos mediadores excitatōrios tornam-se exaltados e os neurōnios passam a apresentar descar gas rāpidas, responsāveis pelo aparecimento das convulsões $(67)$.

A TABELA I I mostra que o extrato de P.alata Dryand. aumenta o tempo de laténcia do efeito estricninico, tanto com a dose de $75 \mathrm{mg} / \mathrm{kg}$ quanto com a de $150 \mathrm{mg} / \mathrm{kg}$ do extrato. O perỉodo de convulsão, representado como tempo de sobrevivēncia, foi aumentado significativamente somente com a dose de $150 \mathrm{mg} / \mathrm{kg}$. Todos os animais morreram, inclusive os do grupo tratado com a substāncia referēncia-diazepan $5 \mathrm{mg} / \mathrm{kg}$.

Embora não tenha impedido o aparec $\underline{i}$ mento das convulsões, o extrato assim como o diazepan determinaram o aumento dos intervaios entre as convulsões tó nicas intermintentes. 
TABELA II

Efeito do extrato de P.alata Dryand. na convulsão estricn nica

\begin{tabular}{lccc}
\hline GRUPOS & $\begin{array}{c}\text { Tempo de Laténcia } \\
\text { (seg.) }\end{array}$ & $\begin{array}{c}\text { Tempo de vida } \\
\text { (seg.) }\end{array}$ & $\begin{array}{c}\text { Mortali } \\
\text { dade(\%) }\end{array}$ \\
\hline Salina - controle & $88,8 \pm 5,42$ & $16,0 \pm 2,31$ & 100 \\
Extrato (75mg/kg) & $109,0 \pm 5,12^{*}$ & $25,7 \pm 4,27$ & 100 \\
Extrato $(150 \mathrm{mg} / \mathrm{kg})$ & $147,0 \pm 2,87^{*}$ & $33,3 \pm 3,72^{*}$ & 100 \\
Diazepan (5mg/kg) & $145,0 \pm 2,75^{*}$ & $38,3 \pm 2,45^{*}$ & 100 \\
\hline * Significante $(p<0,05$, Tukey), em relação ao controle.
\end{tabular}

- Cada valor representa a média + Erro Padrão obtidos de 6 animais.

- Todos os animais receberam 3mg/kg i.p. de estricnina 60 minutos apōs a administração do extrato. 


\subsubsection{3-Convulsão por pentetrazol}

0 pentetrazol é uma droga sintética que provoca intensa estimulação do sistema nervoso central, tendo ação predominante no tronco cerebral. Difere da estricnina na sua ação, pois inibe os neurônios gabaérgicos. Segundo alguns autores, a ação do pentetrazol se verifica nos centros superiores e subcorticais ocasionando o aparecimento das convulsões tōnico clônicas (67).

O extrato de P.alata Dryand. nas do ses empregadas, $75 \mathrm{mg} / \mathrm{kg}$ e $150 \mathrm{mg} / \mathrm{kg}$ i.p., demonstrou um aumento no tempo de latēncia das convulsões induzidas pelo pentetrazol, em relação ao grupo controle, tratado somente com solução salina.

O perīodo em que ocorreram convulsões nos grupos tratados com o extrato de $\underline{\text { palata }}$ Dryand. e com diazepan foi significativamente maior em confronto com o do grupo controle. Ademais, o extrato na dose de $150 \mathrm{mg} / \mathrm{kg}$ previniu a morte em $16,7 \%$ dos animais.

O grupo tratado com diazepan (5mg/ kg i.p.) apresentou comportamento semelhante ao do grupo que recebeu $150 \mathrm{mg} / \mathrm{kg}$ do extrato, no que diz respeito à 1 atência, período convulsivo e proteção dos animais contra o efeito letal do pentetrazol ( $50 \mathrm{ml} / \mathrm{kg} \mathrm{i.p.).} \mathrm{Os} \mathrm{resultados}$ encontrados acham-se reunidos na TABELA III. 
99.

\section{TABELA III}

Efeito do extrato de $\underline{\text {.alata }}$ Dryand. na convulsão por pente trazol em camundongos

\begin{tabular}{lccc}
\hline GRUPOS & $\begin{array}{c}\text { Tempo de latência } \\
\text { (seg.) }\end{array}$ & $\begin{array}{c}\text { Duração da } \\
\text { convulsão } \\
(\text { seg. })\end{array}$ & $\begin{array}{c}\text { Mortali- } \\
\text { dade } \\
(\%)\end{array}$ \\
\hline Controle, sol.salina $0,9 \%$ & $26,1 \pm 1,74$ & $74,6 \pm 4,9$ & 100 \\
Extrato $(75 \mathrm{mg} / \mathrm{kg})$ & $34,0 \pm 1,84^{*}$ & $105,6 \pm 8,1 *$ & 100 \\
Extrato $(150 \mathrm{mg} / \mathrm{kg})$ & $53,3 \pm 6,17^{*}$ & $191,8 \pm 22,5^{*}$ & 83 \\
Diazepan $(5 \mathrm{mg} / \mathrm{kg})$ & $54,5 \pm 3,37^{*}$ & $292,5 \pm 28,5 *$ & 67 \\
\hline * Significante $(p<0,05$, Tukey), em relação a o controle.
\end{tabular}

- Cada valor representa a média t Erro Padrão obtidos de 6 animais.

- Todos os animais receberam $50 \mathrm{mg} / \mathrm{kg}$ i.p. de pentetrazol 60 minutos após a administração do extrato de $\underline{P}$. alata Dryand. 


\subsubsection{4 - Atividade motora espontānea}

Os animais tratados com $3 \mathrm{mg} / \mathrm{kg}$ i.p. de anfetamina, mostraram nitido aumento dos movimentos espontāneos, no intervalo de tempo de 90 minutos de observação. 0 extrato de $\underline{\text { Palata }}$ Dryand. na dose de $150 \mathrm{mg} / \mathrm{kg}$ i.p., inversamente, reduziu os movimentos tanto nos animais previamente tratados com anfetamina ( $3 \mathrm{mg} / \mathrm{kg}$ i.p.) quanto nos do grupo controle, tratado com salina. Os resultados deste experimento estäo representados na Fig. 34 .

\subsubsection{5 - Toxicidade aguda}

0 extrato submetido a teste de toxi cidade aguda, em camundongos, revelou que o efeito letal é causado em doses acima de $432 \mathrm{mg} / \mathrm{kg}$ i.p.. Todos os animais apresentaram sinais de depressão, com sonolēncia, e, em do ses letais, a morte ocorre dentro de 24 horas. A DL $50 \%$ calculada foi de 456 (424 e 491$) \mathrm{mg} / \mathrm{kg}$ i.p...(16) 


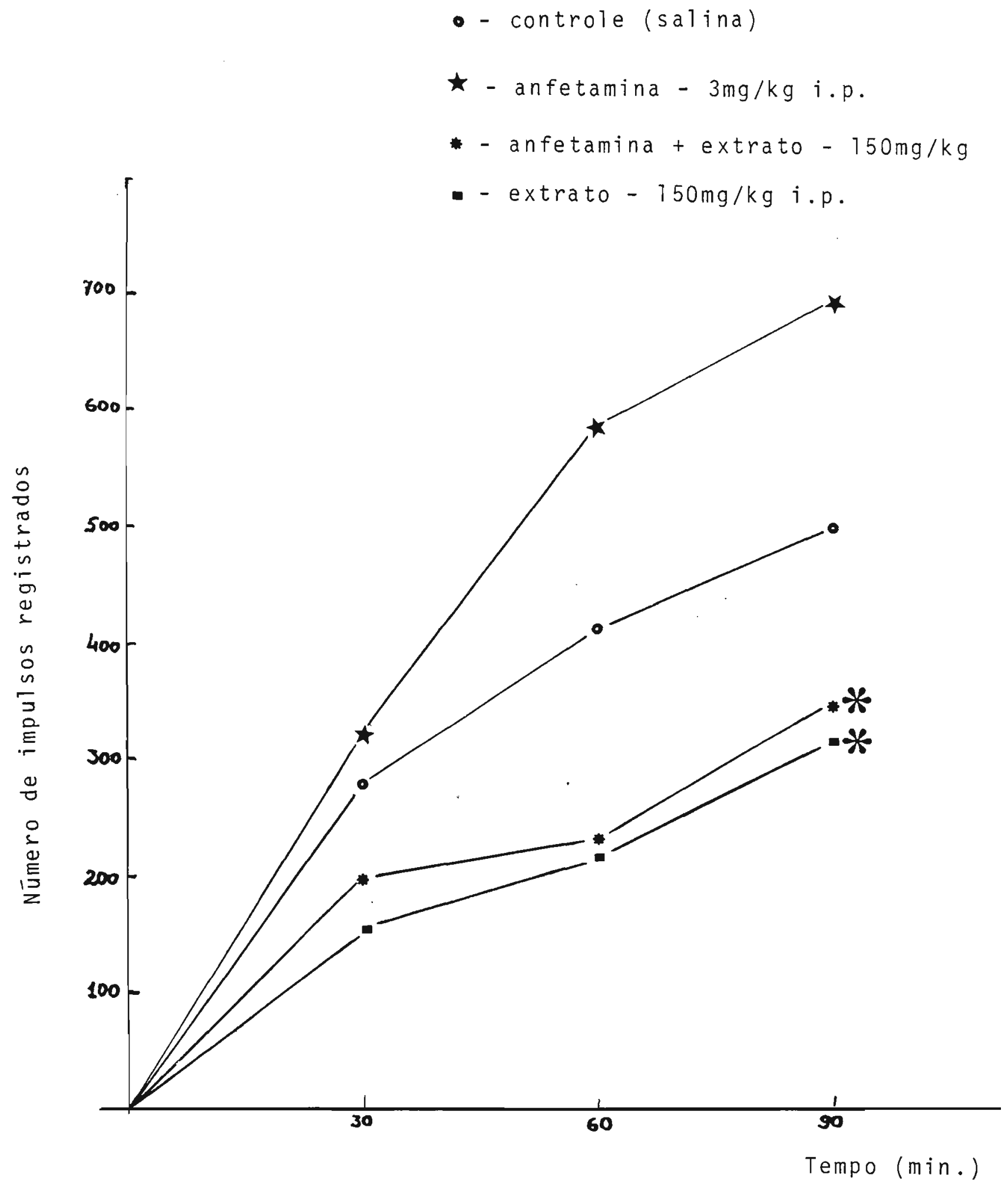

FIGURA 34 - Efeito do extrato de P.alata Dryand. na atividade motora espontānea de camundongos.

* Significante $(p<0,01)$ em relação ao controTe. Cada ponto representa a média obtida de 6 animais. 


\section{5 - DISCUSSAO}

\section{$5.1-$ BOTANNICA}

\section{1 .1 - Caracterização macroscōpica}

O nome vulgar maracujā, de origem tupi-guarani é empregado para designar uma série de espécies vegetais pertencentes ao gēnero botānico Passiflora L. Algumas destas espécies gozam de prestigio por thes serem atribuidas propriedades medicinais. A Farmacopéia Brasileira inclue na lista de suas monografias P.alata Dryand. oficializando-a no Brasil. Além desta, outras espécies são, com frequência, empregadas na elaboração de medicamen tos, entre elas P.incarnata L., P.edul is sims., P.quadrangularis $L$. e p.caerulea $L$.. As diversas firmas que comercializam drogas vegetais obtidas a partir destas espécies, frequentemente enfrentam certa dificuldade na identificação destes materiais. Repetidamente, tais firmas adquirem nas de coletores preocupados única e exclusivamente com a atividade extrativa, sem interesse no cultivo da espécie medicinal, bem como indiferentes à época da colheita e ao processo de transformação adequada das partes vegetais em droga. Por isso, muitas vezes, a droga comercializada no Brasil é de baixa qualidade e não raro apresenta-se frauda da. Com referência a este ūitimo fato é conveniente acres centar que o problema é bem mais amplo e diz respeito de uma maneira geral à major parte das drogas aqui comerciali 
zadas. 01 iveira e Akisue (48) tratando do problema de adul teração de drogas no Estado de São Paulo assinalam o fato de em 100 amostras analisadas $21 \%$ não estavam em condições de uso.

A Farmacopéia Brasileira oficializa as folhas de $\underline{\text { Palata }}$ Dryand.. Entretanto, a droga comercializada na maioria das vezes é representada pelas partes aéreas. A dificuldade maior na diferenciação morfológica deste material em relação a outras PassifloraL. diz respeito a $\underline{\text { Pquadrangularis } L . . ~ A ~ f o r m a ~ d a s ~ f o l h a s, ~ b e m ~ c o m o ~} 0$ aspecto do caule caracteristicamente alado, são bem parecidos nas duas espēcies. Entretanto, a diferenciação pode ser feita se atentarmos para alguns detalhes. Assim, no peciolo de P.alata Dryand. ocorrem quatro glāndulas ao passo

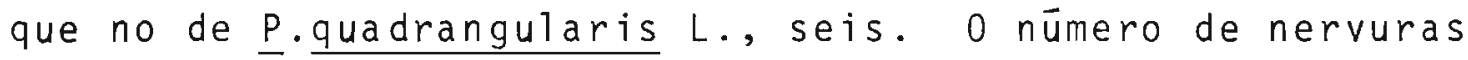
secundārias em $\underline{P}$.quadrangularis L. é aproximadamente o dobro dos existentes em $\underline{\text { P.alata }}$ Dryand.. Além disso, o tama

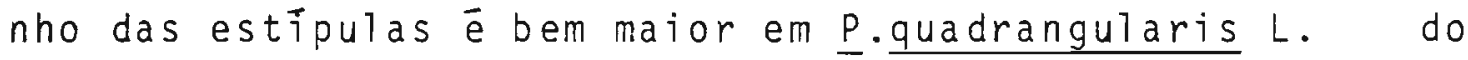
que em $\underline{\text { P.alata Dryand.. }}$

A dificuldade de diferenciação macroscópica destas drogas aumenta com o grau de fragmentação.

A diferenciação de $\underline{\text { P. alata }}$ Dryand. com outras espécies vegetais do gēnero comercializadas, é relativamente fácil, visto estes materiais apresentarem fo1has lobadas:- P.incarnata L. e P.edulis Sims. - e folhas

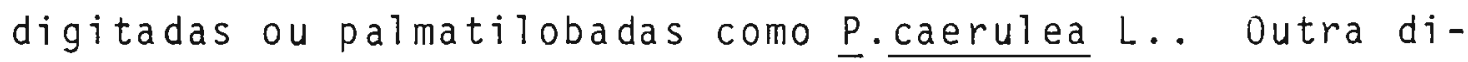
ferenciação que frequentemente preocupa o farmacognosta é 
aquela que diz respeito a $\underline{\text { Pincarnata }} L$. e $\underline{p}$.edulis Sims. Esta diferenciação pode ser efetuada se atentarmos para o fato de a margem da folha de $\underline{p}$.edulis sims. ser mais evidentemente serrilhada do que a de $\underline{P}$.incarnata L.. Acresce-se ainda o fato de a folha de $\underline{P}$ edulis sims. ser um tanto irregular não se conseguindo apla inā-la totalmente quando a prensamos entre folhas de papel absorvente. Por outro la do, a face dorsal da folha de $\underline{\text { Pincarnata }}$ L. é pubescente - que pode ser observado com auxîlio de lupa, fato estenão observado em $\underline{P}$.edulis sims..

Algumas outras espécies de passiflo ra L. aparecem no comércio, exigindo da pessoa encarregáda da diagnose, atenção e observação de sutilezas.

\section{1 .2 - Caracterização Microscōpica}

Segundo Metcalfe e Chalk (43) as fo 1 has pertencentes a espēcies da famīlia Passifloraceae, sal vo algumas exceções possuem mesofilo heterogēneo e assimé trico. As espēcies estudadas neste trabalho não fogem a este aspecto geral ou melhor $\underline{p}$.alata Dryand., $\underline{p}$.quadrangula

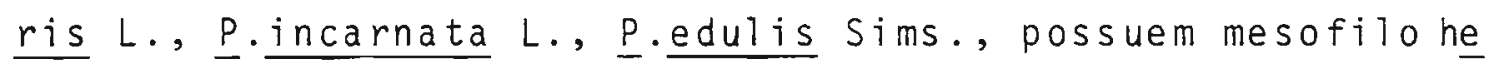
terogêneo e assimétrico.

A Farmacopéia Brasileira, tratando

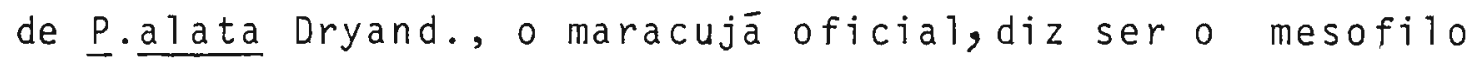
desta espēcie heterogēneo e assimētrico sendo formado na parte superior por 2 a 3 fileiras de cēlulas em paliçada. Discordamos do conteúdo da Farmacopéia Brasileira quando menciona o parênquima paliçādico. 
105.

A observação demorada desta região da folha em materiais de diversas procedencias permitiu-nos verificar que o parēnquima paliçādico é geralmente constituído de apenas uma fileira celular e menos frequentemente por duas fileiras celulares. Não conseguimos observar em nenhuma das amostras estudadas trēs fileiras de parēnquima paliçādico. Somos de opinião que este item seja modificado na prōxima edição do código Farmacēutico Brasileiro.

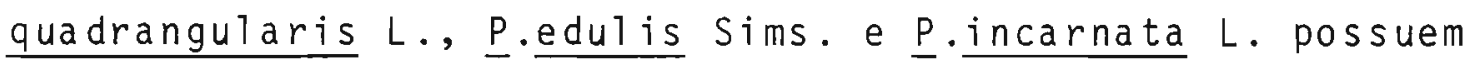
também uma sō fileira de cēlulas em patiçada.

O parênquima paliçādico de $\underline{P}$. al ata Dryand. frequentemente aparece mais frouxo do que o de $\underline{P}$. quadrangularis L.. Já o parénquima paliçādico de $\underline{\text { Padulis }}$ Sims apresenta características muito próximas daquelas ob servadas em $\underline{P}$. incarnata $L$.

As quatro espécies estudadas possuem inclusão de oxalato de cālcio do tipo drusa. A quantidade de drusas observada em $\underline{\text { P.alata }}$ Dryand. é bem maior do que em $\underline{P}$.quadrangularis L. Além disso, em $\underline{\text { Palata }}$ Dryand. as drusas acham-se distribuĩdas por todo o parénquima lacunoso ao passo que em $\underline{P}$.quadrangularis L. 1ocalizam - se de preferéncia nas bainhas que envolvem os feixes vasculares.

Segundo Metcalfe e Chalk (43) pēlos tectores simples cônicos e as vezes em forma de gancho apa recem com certa frequēncia no gēnero passiflora L. As fo-

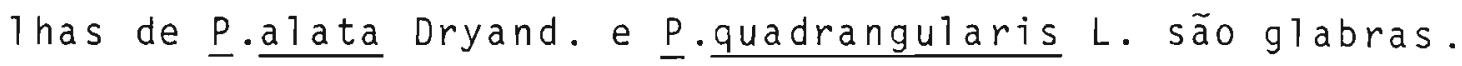


106.

P.edulis Sims. apresenta epiderme provida de pēlos simples cōnicos e curtos ao passo que $\underline{\text { Pincarnata }}$ L. apresenta pêlos tectores em maior quantidade, especialmente localizados sobre a epiderme inferior. Estes pêlos são cônicos e providos de uma a cinco células. Fato digno de nota e importante sob o ponto de vista da diagnose do vegetal è a presença de estrias sobre a cutícula que recobre estes tri comas. Já $\underline{\text { P.caerulea }} L$. é desprovida de pélos tectores co mo afirma Brasseur e Angenot (8).

A região da nervura mediana apresen ta-se carenada nas quatro espēcies estudadas.

As folhas apresentam estōmatos somente do lado da epiderme inferior.

Como nas Passifloraceae de um modo geral (43), as espécies de Passiflora L. estudadas não apre sentam hipoderme.

Os peciolos de $\underline{\text { Palata }}$ Dryand. apre sentam-se canaletados. Os feixes vasculares distribuem-se em dois conjuntos. 0 conjunto localizado na região mediana dispõe-se aproximadamente em cîrculo.

0 outro conjunto è representado $\Gamma^{n} r$ do is feixes localizados nas alas, um de cada lado da cana1eta. Fato semelhante ao mencionado por ūitimo ocorre em $\underline{P}$-quadrangularis L. e $\underline{P}$.edul is Sims.. Com referéncia a $\underline{P}$. incarnata L. cada uma das alas possui dois feixes vasculares. 
Cristais de oxalato de cálcio em for ma de drusas ocorrem no parēnquima fundamental e no parênquima do floema dos peciolos das quatro espécies estuda das.

Secções transversais dos caules de P.alata Dryand. e de $\underline{P}$-quadrangularis L. mostram contorno quadrangutar a tado e estrutura eustética. As duas espēcies apresentam, caracteristicamente, colênquima angular subepidérmico, e nas regiões das alas, grupos de fibras. A região medular nas duas espécies é bem desenvolvida e na droga algumas vezes pode ser observada a presença de fístü la, motivada pela retração do tecido parenquimático devido ao processo de secagem. Os feixes vasculares das duas espécies são protegidos por periciclo fibroso que é mais de-

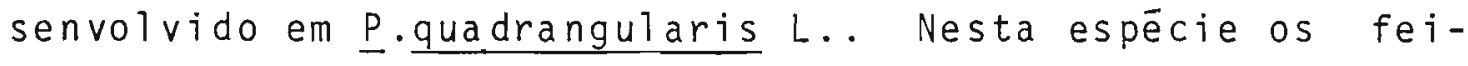
xes vasculares de maior calibre, localizados nas regiões adjacentes às alas, apresentam as fibras dispostas em três calotas.

0 nūmero de feixes vasculares localizados nas regiões que ficam entre as alas é menor em . alata Dryand. do que em $\underline{p}$.quadrangularis L. O caule das duas espécies inclue drusas de oxalato de cālcio.

o caule de P.edulis sims.e o de P.in carnata L. apresentam contorno aproximadamente circular em secções transversais. O caule de $\underline{P}$.incarnata L. apresenta -se algumas vezes ligeiramente penta-anguloso e provido de pêlos tectores cōnicos os quais não foram observados em $\underline{p}$. edulis sims. 
A presença de drusas pode ser obser vada no caule das duas espécies. Fístula decorrente da se cagem pode ser observada nos caules de ambas as espécies.

A diferença entre P.edulis Sims. e P. incarnata L. no que diz respeito as drusas segundo Brasseur e Augenot (8) reside no fato de estes cristais ocorrerem em maior quantidade na primeira espécie onde são bem pequenas na região do colênquima, um pouco maior na região cortical e floemática e bem maiores na região da medula. Estes autores citam como localização destas inclusões no caule de $\underline{P}$.caerulea L., a região cortical.

\section{2 - QUIMICA}

Com a introdução do maracujā - $\underline{P}$. $\underline{\text { in }}$ carnata L. - na medicina clássica, ocorrida em 1867 , o estudo químico do gênero sofreu o seu primeiro alento. os re sultados positivos no tratamento de insōnia, proclamados por stapleton (29) incentivou a pesquisa dos componentes químicos farmacologicamente ativos.

Em 1909, Peckolt (3) trabalhando com vārias espécies brasileiras conseguiu isolar duas subs tâncias. Uma delas obtida em forma cristalina e por ele denominada passiflorina, a outra, amorfa - a maracujina. Com mais recursos Neu (44) desenvolveu trabalhos de isolamento e purificação de substâncias básicas no extrato alcoōlico de P.incarnata L. Este autor confirmou a presença de um 
a lcalóide de estrutura idêntica à 3-metil-4-carbolina, conhecidocomo harmana. Seguiram-se vārias pesquisas com os maracujās objetivando a identificação e avaliação de compostos $\beta$-carbolinicos tais como:- harmina, harmol, harmalina e harmalot.

A existência de harmana em $\underline{P}$. alata Dryand. pode ser evidenciada pela primeira vez, cromatogra ficamente, em nosso trabalho. Ao lado deste fato, logramos confirmar a presença daquela substāncia em $\underline{P}$. edulis Sims., P.incarnata L. e $\underline{P}$.quadrangularis L.. Na fração al caloídica de P.alata Dryand. o composto que ocorre em maior quantidade é harmana. Este alcalóide aparece, comparativa mente, em maior concentração em $\underline{p}$. edulis sims. e em quanti dade bem menor em $\underline{\text { pincarnata }}$ L..

O perfil cromatogrāfico da fração alcaloídica de P.quadrangularis L. evidencia número maior de substancias fluorescentes que o das outras espécies.

Os resultados obtidos na avaliação quantitativa de alcalóides B-carbolínicos em drogas de ori

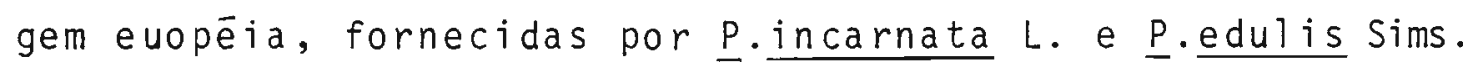
apresentam variações significativas conforme pode ser visto no quadro seguinte. 
110.

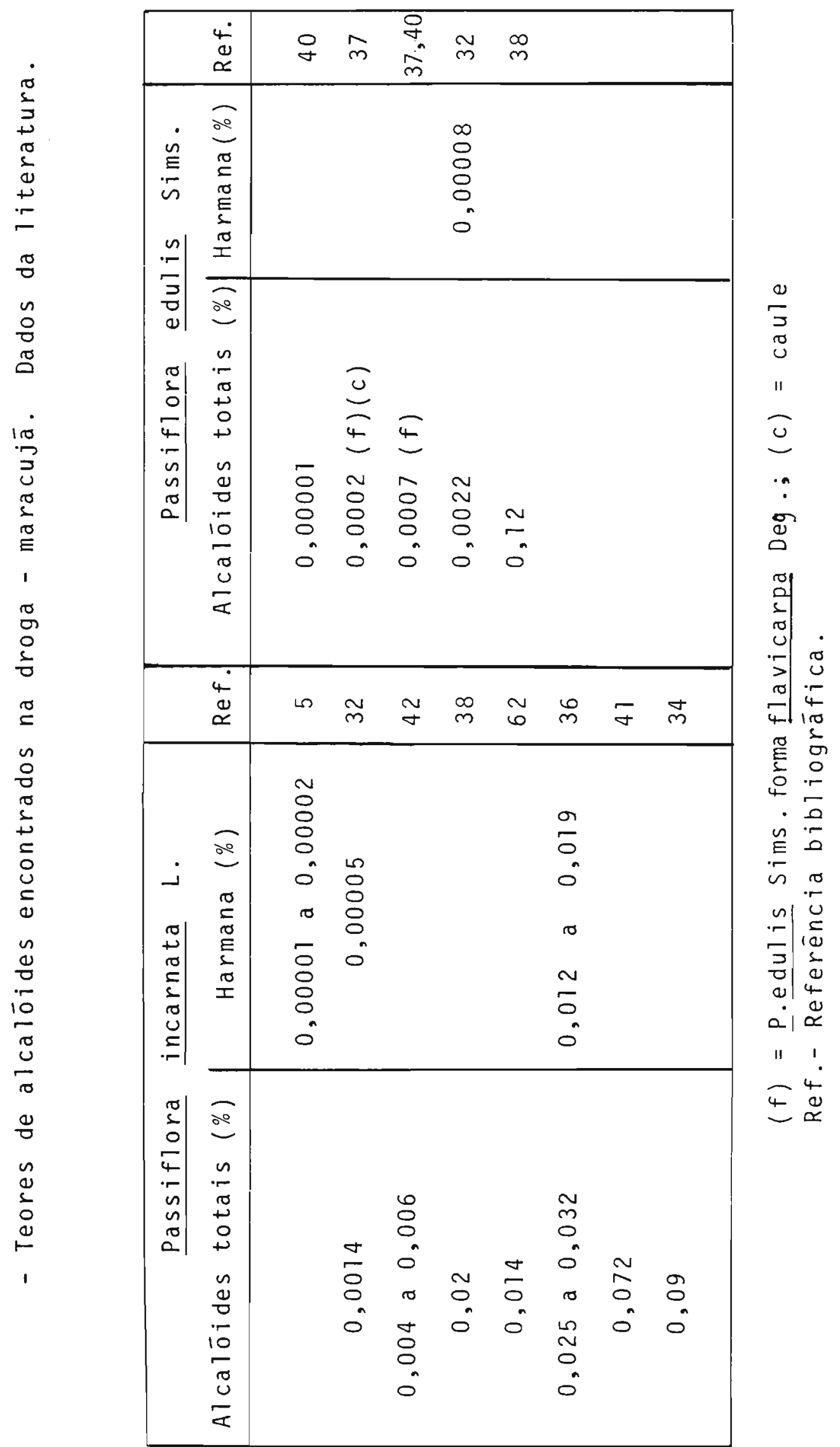


A discrepãncia dos valores indicados deve-se em parte $\bar{a}$ metodologia aplicada na quantificação das substâncias. Lohdefink e Kating (32) analisando extra tos metanólicos de algumas espécies de Passiflora L., quan to ao seu teor alcaloídico, atravēs de mētodos titulomëtri co e espectrofotométrico, evidenciaram esta desparidade de resultados, exemplificada no quadro seguinte.

\begin{tabular}{lc|c}
\hline & TITULOMETRIA & ESPECTROFOTOMETRIA \\
\hline & $\mu \mathrm{g}$ de alcalóides/100g droga & $\mu \mathrm{g}$ harmana/100g droga \\
$\underline{P} \cdot \underline{\text { edulis }}$ & 2.200 & 85 \\
$\underline{P}$. incarnata & 1.400 & 55 \\
\hline
\end{tabular}

Alēm disso, pode-se considerar como fatores de variação dos teores alcaloídicos em drogas, os ōrgãos vegetais empregados, a ëpoca e os locais das colhei tas. Assim, Lutomski e Malek (37), analisando diferentes ör gãos de $\underline{p}$.edulis sims. forma flavicarpa, encontraram os se guintes resultados:- 0,0007\% e 0,0002\% para folhas e cauTes, respectivamente.

Considerando que a droga comercialmente utilizada $\bar{e}$ representada pelas partes aéreas do vege tal, a variação na quantidade de folhas, em relação ao cau 1e, pode levar a uma queda significante do teor alcaloídico.

Em nosso trabalho, efetuamos a avalia ção quantitativa dos alcalóides B-carbolínicos fluorescen-

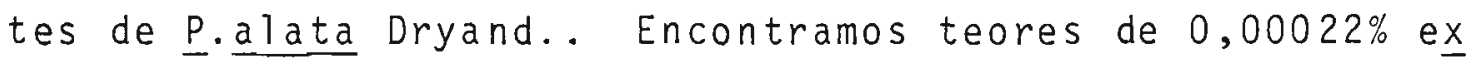
pressos como harmana, utilizando folhas adultas, secas à 
sombra, provenientes de espēcimes cultivados em Jaboticabal e em fase de floração.

De acordo com o raciocinio anterior, $\bar{e}$ de se esperar que a quantidade destes alcalóides nas dro gas comercializadas em São Paulo seja diferente daquela por nös encontrada, visto que o material vendido no comércio farmacēutico é constituído na sua maior parte por frag mentos de caule.

outro grupo de substāncias presente nos maracujās e que vem merecendo cada vez mais a atenção dos pesquisadores é o dos flavonóides. Schindler (41) em 1955 relatou pela primeira vez a presença de compostos fla vonoídicos na tintura de P.incarnata L.. Este achado foi comprovado por Lutomski e Wrocinski (41) que encontraram 4 substāncias na anālise da fração flavonoídica da espécie em questão. A identïficação destas substāncias somente có meçou a ocorrer a partir de 1968 com Glotzbach e Rimpler (24). Os resultados das anāi ises cromatogrāficas encontra dos por estes autores trabalhando com $\underline{P}$.incarnata $L$. e $\underline{P}$. quadrangularis $L$. foram confirmados em nosso trabalho. In tegram a fração fravonoídica das 4 espēcies por nós estuda das, os seguintes compostos:- vitexina, orientina, isovitexina e isoorientina.

0 quadro seguinte reune dados da $1 \mathrm{i}-$ teratura referentes a espécies em estudo quanto a seu teor flavonoídico. 


\begin{tabular}{|c|c|c|c|c|}
\hline Passiflora & incarnata $L$. & Ref. & Passiflora edulis Sims. & Ref. \\
\hline 1,5 & a $2,1 \%$ & 60 & $0,001 \%$ (f) & 40 \\
\hline 0,2 & a $\quad 0,8 \%(c)$ & 60 & $0,001 \%$ & 40 \\
\hline 1,5 & a $2,2 \%$ & 61 & & \\
\hline 0,15 & a $\quad 0,31 \%$ & 21 & & \\
\hline & $44 \%$ & 62 & & \\
\hline
\end{tabular}

(f) - P.edulis Sims. forma flavicarpa - (c)-caule.

Ref.- Referēncia bibliogrāfica.

A semelhança do que ocorre com a fra ção alcalóidica, a fração flavonóidica tambēm estā sujeita a variações no seu conteūdo. A época de colheita, a parte da planta que constitui a droga, o local de cultivo e a me todologia empregada são responsāveis por estas variações. os resultados encontrados por schilcher (61) mostraram que

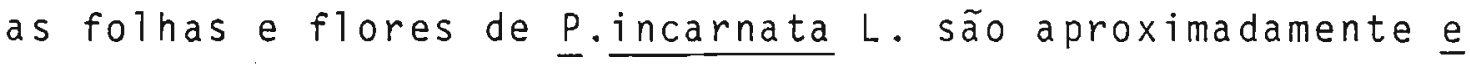
quivalentes quanto ao teor de flavonōides totais, enquanto estes compostos ocorrem nos caules em quantidade aproximadamente 4 vezes menor.

A anālise cromatográfica das frações flavonoídicas das espécies por nós estudadas evidenciouser $\underline{P}$.edulis sims. a espēcie com major nūmero de substāncias

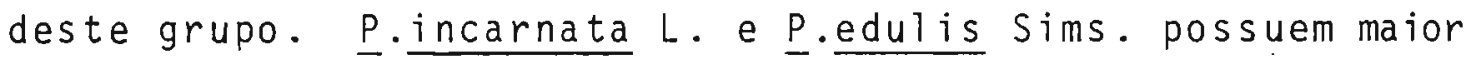
concentração de flavonóides do que $\underline{\text { Palata }}$ Dryand. e $\underline{\text {. }}$. quadrangularis $L$. 
114.

E interessante notar certa semelhança entre o perfil cromatogrāfico da fração flavonōidica de

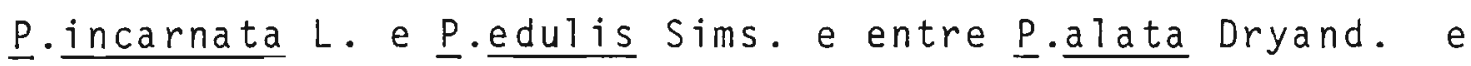
$\underline{P}$.quadrangularis $L$.

Observando-se o cromatograma compara tivo pode-se verificar que o glicósido flavonoídico vitexi na aparece em maior quantidade em $\underline{P}$. incarnata L. seguindose $\underline{P}$.edulis sims. e $\underline{P}$.quadrangularis L.. o teor deste com posto de $\underline{\text { palata }}$ Dryand. é relativamente pequeno; sendo es te vegetal o que apresentou menor quantidade de flavonói des.

Comparativamente, o flavonōide isovitexina aparece em quantidade alta em $\underline{p}$.edulis sims. e $\underline{\text { e }}$

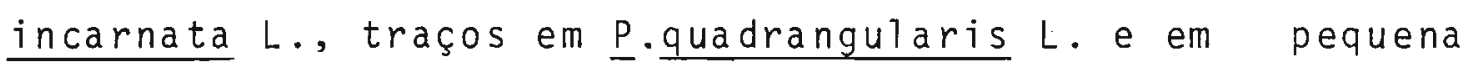
concentração em $\underline{\text { Palata }}$ Dryand.. Orientina ocorre em maior quantidade em $\underline{P}$.incarnata L. e $\underline{P}$.edulis Sims. $\underline{\text { e alata }}$ Dryand. apresentou traços desta substāncia, ao passo que em $\underline{P}$-quadrangutaris $L$. seu teor é pouco maior. 
Vários são os experimentos laboratoriais objetivando precisar a atividade farmacológica dos maracujās, especialmente de seus extratos, procurando rela cionā-la à composição quỉmica. Tratando-se de extrato vegetal, mistura complexa de substāncias, é difícil atribuirse ação farmacológica a um ūnico composto. A atividade fi nal é quase sempre resultado de sinergismos e antagonismos.

\section{Os extratos de P.incarnata L., a es-} pécie de maracujā melhor estudada, tiveram ação hipotensora evidenciada por trabalhos realizados por Fellows (19) e Ruggy (56).

Efeitos, hipotensor, antiinflamatório e antiespasmódico do flavonöide vitexina, foram consta tados por Prabhakar et a1. (51) em 1981. A presença deste composto na espécie mencionada poderia, até certo ponto, justificar a atividade hipotensora encontrada nas pesquisas anteriormente citadas.

A presença em quantidade significati va de vitexina na fração flavonoídica de P.edulis Sims. e

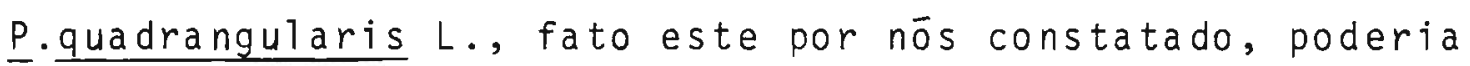
sugerir igual efeito para os extratos destas plantas.

A atividade sedativa de $P$. incarnata L. foi evidenciada por Cavazzuti (10), Gagiu (20), Lutoms ki e Wrocinski (41) e Lutomski et al. (36). Estes autores 
116.

põem em destaque a importāncia da presença conjunta das frações alcaloídicas e flavonoídicas na eficiência do resultado terapēutico.

Lutomski et a 1. (40) estudando sucos obtidos de $\underline{P}$.edulis sims. forma flavicarpa e de $\underline{P}$. edulis Sims. concluiram que, apōs administração oral a camundongos, houve diminuição significativa da movimentação espontānea dos animais bem como diminuição da irritabilidade, e aumento no tempo de busca a alimentos. Semelhantes resultados foram encontrados por valle e colaboradores (66) que trabalharam com as folhas dos vegetais.

Segundo o raciocinio de que o fitocomplexo fração alcalōidica-fração flavonōidica, é importante, para a ação sedante dos maracujās, trabalhamos com o extrato hidro-alcoólico integral das folhas de $\underline{\text { P alata }}$ Dryand.

Pelos resultados laboratoriais obti dos pudemos verificar a ação depressora do sistema nervoso central de modo semelhante a dos estudos anteriormente citados. 0 extrato de P. alata Dryand., nas doses de $75 \mathrm{mg} / \mathrm{kg}$ e $150 \mathrm{mg} / \mathrm{kg}$, demonstrou ação potenciadora sobre o sono indu zido pelo pentabarbital em ratos. Em outro experimento po de-se verificar tambēm que o referido extrato na dose de $150 \mathrm{mg} / \mathrm{kg}$ aumentou o tempo de latência na convulsão provoca da por estricnina. 0 extrato de maracujā não impediu o aparecimento das convulsões estricnīnicas porém tornou-as mais brandas e espaçadas. Fato semelhante fo'i também ob- 
servado em relação a convulsão tōnico-clōnica induzida pe10 pentetrazol.

Constatação semelhante $\bar{a}$ obtida com

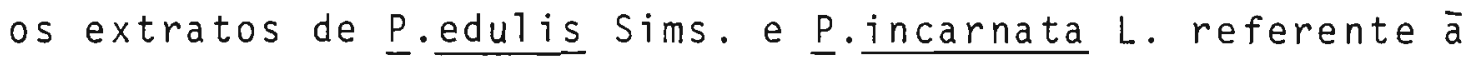
diminuição da atividade motora espontānea em ratos, foi ob servada em nosso trabalho com o extrato de $\underline{\text { Palata Dryand. }}$

A atribuição da responsabilidade da ação terapēutica sedativa dos maracujās a algum composto ou mesmo a grupo de compostos quỉmicos é ainda matēria de discussão.

Até meados da década de 60 as preparações fitoterapéuticas contendo Passiflora spp. colocaram em realce a presença de alcalóides B-carbalínicos. Este po sicionamente aos poucos foi sendo deslocado para os compos tos de natureza flavonoídica, sem entrentato, ocorrer fato que justificasse este procedimento.

Concomitantemente, alguns pesquisado res, atribuem a propalada ação sedante a glicōsidos triter pénicos como Bombardeli, por exemplo (6). Para Ayoagi(2) esta atividade deveria estar relacionado com derivados da pirona como o maltol.

A atividade sobre o sistema nervoso de extratos elaborados a partir de espécies do gēnero Passiflora L. não pode ser totalmente explicada considerando- como decorrēncia da presença de compostos isolados ou mesmo de categorias isoladas de princípios ativos. 
118.

Alguns alcalóides $\beta$-carbolínicos são conhecidos como inibidores da MAO (67) e relatados como es timulantes do sistema nervoso central. Entre estes alca10 ides cita-se, especialmente, a harmalina e a harmina.

A ação alucinogēnica do "yagē" ou "caapi", Banisteriopsis caapi (Spruce ex Grise1.) Morton cos tuma ser atribuĩda a estes alcalóides (27).

Dolzhenko (15), em 1982, refere a ação tranquilizante de harmana mencionando que sua ativida de difere do diazepan e que não demonstra possuir ação relaxante muscular. Trabalhos recentes de Rommelspacher(54, 55) demonstram que a harmana é um potente inibidor endōgeno dos receptores benzodiazepinicos.

Com referéncia a fração flavonoídica foram Lutomski e Wrocinski (41) os únicos autores que atri buīram a estas substāncias, pelo menos parte da atividade sedante dos maracujās. Estes autores encontraram atividade tranquilizante da referida fração em peixes e camundongos.

Ao nosso ver a pretendida relação en tre composição quîmica dos maracujās e a atividade farmaco iógica se afigura comu extremamente complexa. Posição da equidistāncia das diversas correntes de opiniões parecenos o mais prudente. 


\section{$6-$ CONCLUSÕES}

1 - São características importantes na morfodiagnose das drogas:

- Passiflora alata Dryander

Características macroscōpicas: folhas de contorno oval ou oval-oblongo, de consistēncia membranācea ou subcoriāceas; pecĩolo provido de qua tro glāndulas; caule quadrangular a lado.

Caracterīsticas microscōpicas: fol has com mesofilo heterogēneo e assimētrico, geralmente com uma ünica fileira de cēlulas em paliçada; presença de drusas em todas as regiões parenquimāticas; ausēncia de pēlos; caule de estrutura eustélica pro vido de secção transversal quadrangular alada, presença de grupo de fibras nas regiões de alas caulinares.

\section{- Passiflora quadrangularis $L$.}

Caracterīsticas macroscōpicas: folhas de contorno oval ou oval-oblongo, de consistēncia membranācea ou subcoriācea; peciolo provido de seis glāndulas; caule quadrangular alado.

Caracterīsticas microscōpicas: follhas com mesofilo heterogēneo e assimétrico provido de uma ünica fileira de cēlulas em paliçada; presença, 
de drusas localizadas junto a região floemática dos feixes vasculares; ausēncia de pēlos; caule provido de secção transversal quadrangular alada e de estru tura eustēlica; presença de grupos de fibras nas re gioes de alas cautinares.

\section{- Passiflora edulis sims.}

Características ma croscōpicas: fol has trilobadas de contorno arredondado nitidamente de margem serrilhada; superficie do limbo foliar não perfeitamente aplainável; glabras; pecĩolo provido de duas glāndulas; caule cilindrico estriado longitidinalmente.

Características macroscōpicas: fol has com mesofilo heterogēneo assimētrico, provido de paliçada com uma ūnica fileira celular; presença de drusas espalhadas pelas regiões parenquimáticas; pre sença de pêlos tectores cōnicos, curtos, localizados especialmente nas regiöes de nervuras; caule de secção transversal arredondada, de estrutura eusté1 ica; presença de drusas cujo tamanho aumenta da re gião externa para o interior da estrutura.

\section{- Passif. ura incarnata $L$.}

Caracteristicas macroscōpicas: folhas trilobadas de contorno arredondado e margem esparsa mente serrilhada; superfície do 1 imbo foliar perfei tamente aplaināvel; pecíolo provido de duas glàndu- 
1as; face dorsal pubescente; caule cilindrico, estriado longitudinalmente.

Características microscópicas: fol has de mesofilo heterogéneo e assimétrico provido de pa liçada com uma única fileira celular; presença de drusas; pêlos tectores relativamente longas formados por 1 a 4 cēlulas dispostas em uma série e possuidores de cutícula estriada; caules de secção trans versal arredondada, do tipo eustēlico; presença de drusas nos parēnquimas cautinares.

2 - E possivel diferenciar cromatograficamente os extratos fluidos de Passiflora alata Dryand., Passiflora quadrangularis L., Passiflora edul is sims. e Passiflo ra incarnata L..

3 - Foi confirmada a presença de vitexina, isovitexina e orientina na fração flavonoídica dos extratos fluidos de $\underline{p}$. incarnata L., $\underline{P}$.edulis sims. e $\underline{p}$. quadrangularis L. .

4 - Foi verificada a presença de vitexina, isovitexina e orientina na fração flavonoídica do extrato fluido de $\underline{\text { P. alata }}$ Dryand..

5 - Foi confirmada a presença de harmana nas fraçōes alca loidicas dos extratos fluidos de $\underline{\text { pincarnata }}$ L. e . edulis Sims.. 
6 - Foi verificada a presença de harmana na fração alcaloidica dos extratos flujdos de $\underline{\text { Palata }}$ Dryand. e $\underline{\text { P }}$. quadrangularis L. .

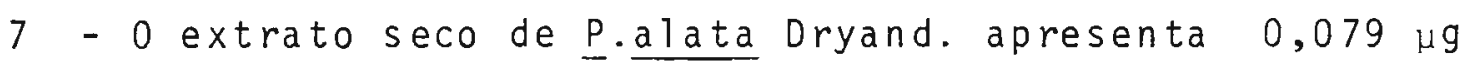
de harmana por $100 \mathrm{mg}$ de extrato.

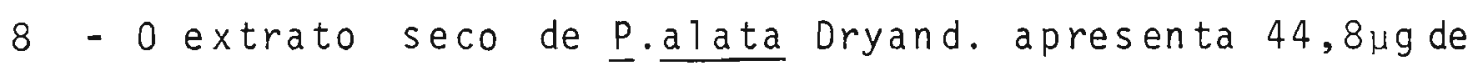
flavonóides por $100 \mathrm{mg}$ do extrato, empregando-se orien tina como padrão.

9 - o extrato seco de P.alata Dryand., nas doses de $75 \mathrm{mg} /$ $\mathrm{kg}$ e $150 \mathrm{mg} / \mathrm{kg}$ exerceu ação potenciadora sobre o pento barbital, causando prolongamento no tempo de sono em camundongos.

10 - 0 extrato seco de $\underline{\text { Palata }}$ Dryand. não impediu o apare cimento das convulsões induzidas pela estricnina, nem pelo pentetrazol, causando apenas uma diminuição na intensidade das convulsões, aumentando o tempo de vida dos animais.

11 - 0 extrato seco de $\underline{\text { Palata }}$ Dryand. diminuiu a atividade motora espontānea de camundongos tratados, pela via intraperitonial, com a dose de $150 \mathrm{mg} / \mathrm{kg}$.

12 - Nos ensajos de toxicidade, aguda em camundongos, por via intraperitonial, o extrato seco de $\underline{\text { palata Dryand. }}$ apresentou $\mathrm{DL}_{50}$ de $456 \mathrm{mg} / \mathrm{kg}$. 
SUMMARY

The objective of the present dissertation is to contribute for the enlargment and engrossment of the available data on the drug known as maracujā as well as on its extracts. Comprised topics include comparative morphodiagnostic studies and illustrations for $\underline{\text { P.alata }}$ Dryand., $\underline{\text { Pquadrangularis L., }}$ P. edulis Sims. and P.incarnata L.. The differentiation and characterization of the above mentioned species in terms of chemical composition was accomplished by thin layer chromatographic techniques. Chromatographical profiles were established for flavonoid and alkaloid fractions on the four species in relation to reference standards orientin, isoorientin, vitexin, and isovitexin (for flavonoids), and harman and harmin (for alkaloids). P.alata Dryand. earned a more detailed study. The quantifications of flavonoid and alkaloid fractions were performed densitometricaly by TLC and expressed as orientin and harman, respectively. Pharmacological assays carried out with extracts included acute toxicity and CNS depressor activity. 
1. Angely, J. - Flora analítica e fitogeogräfica do Estado de São Pau1o. São Paulo, Phyton, 1970. 30 Vol. p.51317.

2. Aoyagi, N. et al. - Studies on Passiflora incarnata L. extract. I. Isolation of maltol and pharmacological action of maltol and ethyl maltol. Chem.Pharm.Bull., Tokyo, 22 $(5): 1008-13,1974$.

3. Benigni, R.; Capra, C.; Cottorini, P.E.-Piante Medicinali. Chimica, Farmacologia e Terapia. Milano, Inverni. \& Della Beffa, 1964. p. 1080-85.

4. Bennati, E. - Riconoscimento per cromatografia su strato sottile de 11 'estratto fluido di Passiflora incarnata L. Boll.Chim.Farm., Milan, 106:756-61, 1967.

5. Bennati, E. - Determinazione quantitativa del1'armano e dell'armina nell estratto di Passiflora incarnata L.. Bol1.Chim.Farm., Milan, 110:664-69, 1971.

6. Bombardel1i, E. et al. - Passiflorine, a new glycoside from Passiflora edulis sims.. Phytochemistry., New York, 14 (12): 2661-5, 1975.

7. Borgatti, G. - Studio di farmacodinamia sulla Passiflora incarnata L.. Boll.Soc.Ital.Biol.Sper., Naples, 14: 203-5, 1939 . 
8. Brasseur, T. \& Angenot, L. - Contribuition a l'etude. pharmacognostique de la passiflore. J. Pharm. Belg., 39 (1): $15-22,1984$.

9. Caminhoá, J.M. - Elementos de Botänica Geral e Médica. Rio de Janeiro, Typographia Naciona1, 1877. p.2166-7.

10. Cavazzuti, G.B. - Clinical pharmacology of a plant extract $\gamma$-amino- $\beta$-hydroxybutyric acid combination use for infants with behavior disturbances and insomnia. Clin.Ter., Rome, 51 (1): 15-19, 1969. Apud. Chem. Abstr., Columbus, $\underline{72}: 99037 p ., 1970$.

11. Correa, M.P. - Dicionārio de Plantas Uteis do Brasil. Rio de Janeiro, Instituto Brasileiro de Desenvolvimento Floresta1, 1974. Vol. V, p. 108-129.

12. Costa, A.F. - Farmacognosia. 2a ed. Lisboa, Calouste Gulben kian, 1978. II Vol. p. 633-5.

13. Cronquist, $A$. - An integrated system of classification of flowering plants. New York, Columbia University Press, 1981. p. 412-15.

14. Cunha, A.G, - Dicionārio Histōrico das Palavras Portuguesas de origem Tupi. São Paulo, Melhoramentos, 1978. p. $205-6$.

15. Dolzhenko, A.T. et al. - Tranquilizing activity of harman and.3-methyl-harman. Khim.Farm.Zh., 16 (12): 1474-6, 1982. Apud. Chem.Abstr., Columbus, 98 : $137492 \mathrm{e}, 1983$. 
16. Engler, A. - Syllabus der Pflanzenfamilien. Berlin-Niko lassee, Gebrüder Borntraeger, 1964. Vol. II. 666 p.

17. FARMACOPE IA Brasileira. 3â ed. São Paulo, Organização Andrei, 1977. p. 839-840.

18. FARMACOPEIA dos Estados Unidos do Brasil. 2á ed. S.Pau10, Ind.Graf.Siqueira, 1959. p. 561 .

19. Fellows, E.J. \& Smith, C.S. - The chemistry of Passiflo ra incarnata L.. J.Am.Pharm.Ass., Washington, 27 (7) : $565-73,1938$.

20. Gagiu, F. et al. - Sedative chewing gum. Rom. 59589 (C1. A61k9/00), 30 nov. 1975, App1. 66. 300, 23 Mar. 1971, 2 pp. Apud. Chem.Abstr., Columbus, $89: 48897 n$, 1978.

21. Gavasheli, N.M. - Flavonoids of the lemon plant. Passiflora incarnata L.. Sobshch. Akad. Nauk. Gruz. SSR., Tiflis, 60 (2): 353-6, 1970. Apud. Chem. Abstr., Columbus, 74 : $72818 y, 1971$.

22. Gavasheli, N.M. et a1. - Oxycoumarins of P. incarnata L. Khim.Prir.Soedin., Tashkent, 9 (4) : 552, 1973. Apud. Chem.Abstr., Columbus, 80 : $118198 a, 1974$.

23. Gavasheli, N.M. et a1. - Flavonoids from P.incarnata L. Khim.Prir.Soedin., Tashkent, 10 (1): 95-6, 1974. Apud. Chem.Abstr., Columbus, 81 : 60811x, 1974 .

24. Glotzbach, B. \& Rimpler, H. - Die flavonoide von $\underline{P}$. incarnata L., P.quadrangularis L. und P.pulchella H.B.K. Planta Med., Stuttgart, 16 (1): 1-7, 1968. 
25. Halim, M.M. \& Colins, R.P. - Anthcyanins of Passiflora quadranqularis L. Bul1. Torrey Bot.Club., (New York), 97 (5) : 247-8, 1970. Apud. Chem.Abstr., Columbus, 74: $61581 \mathrm{~g} ., 1971$.

26. Hoehne, F.C. - Plantas e substāncias vegetais tōxicas e medicinais. São Paulo, Departamento de Botānica do Estado, 1939. p. 199-201.

27. Holmstedt, B. et al. - Ayahuasca, caapi ou yagē - bebida alucinogēnica dos indios da bacia amazōnica. Ciênc. Cu1t., São Pau1o, 31 (10): 1120-24, 1979.

28. Killip, E.P. - The American Species of Passifloraceae. Chicago, Field Museum of Natural History., vol. 19, 1938. $613 \mathrm{p}$.

29. Leclerc, H. - Prēcis de Phytothërapie. Paris, Masson et cie, 19.27.p. 254-5.

30. Leitão Filho, H.F. \& Aranha, C. - Botânica do Maracujazeiro. In: SIMPÓSIO-CULTURA DO MARACUJA. 1971. Campinas. Secretaria da Agricultura, 1974. p. 1-13.

31. Löhdefink, J. - Untersuchungen zur Flavonoidführung eini ger Passiflora-Arten. [Pesquisa para determinação de flavonōides em algumas espēcies ae Passiflora.]. Dtsch. Apoth-Ztg., Stuttgart, 116 (16): 557-60, 1976 .

32. Löhdefink, J. \& Kating, H. - Zur frage des vorkommens von harmanalkaloiden in Passiflora-Arten. Planta Med., Stuttgart, $25: 101-4,1974$. 
33. Lutomski, J. - The content determination of harman, har mine and harmol in plant material. Biul.Inst. Roslin Lecz., Poznan, $\underline{5}$ : 169-81, 1959. Apud. Chem.Abstr, Columbus, $\underline{54}: 16752 a, 1960$.

34. Lutomski, J. - Qualitative and quantitative chromatogra phic investigations of alkaloids of P.incarnata L. Biul. Inst.Roslin Lecz., Poznan, $\underline{5}$ : 182-98, 1959. Apud. Chem.Abstr., Columbus, $\underline{54}: 16751 \mathrm{f}, 1960$.

35. Lutomski, J. \& Adamska, M. - Wyodrebnienie witersyny z frakcji flawonoidowez ziela pasyflory cielistej. ( siflora incarnata L.). (Extração da vitexina a partir da fração flavonoidica de P.incarnata L.]. Herba Pol., Poznan, 14 (4): 249-52, 1968.

36. Lutomski, J.; Adamska, M.; Jaruzelski, M. - Proste alka loidy karbokinowe. V. Analiza poröwrawcza skladnikōw zasadowych meczennicy cielistej (Passiflora incarnata L.) Z yprawy szklarniowej i gruntowej. [Alcalóides car bonîlicos simples. V. Anālise comparativa dos constituintes básicos de P.incarnata L. a partir de estufa e cultura]. Herba Pol., Poznan, 14 (3): $139-47$, 1968.

37. Lutomski, J. \& Malek, B. - Pharmakochemische undersuchungen von drogen der gattung Passiflora L.: 3. Mitteilung: Phytochemische Forschung der drogen aus Passiflora edulis sims. forma flavicarpa. (Pharmacomiche cal investigations on raw materials genus passiflora. 
3. Phytochemical investigations on raw materials of Passiflora edulis Sims. forma flavicarpa). Planta Med., Stuttgart, 27 (3): 222-5, 1975.

38. Lutomski, J. \& Malek, B. - Pharmakochemische undersuchungen der drogen der gattung Passiflora L. 4. Mittlg.: Der vergleich des alkaloidgehaltes in verschiedenen harmandrogen. (Pharmacological investigation on raw materials of the genus Passiflora L. 4. The comparison of contents of alkaloids in some harman raw mate rials). Planta Med., Stuttgart, 27 (4):381-4, 1975.

39. Lutomski, J. \& Malek, B. - Phytochemical studies of drugs from Passiflora edulis sims. forma flavicarpa. Herba Hung., Budapest, 15 (2): 7-11, 1976. Apud. Chem.Abstr., Columbus, 85 : 59630 p., 1976.

40. Lutomski, J.; Malek, B.; Rybacka, L. - Pharmacochemical investigation of the raw materials from Passiflora L. genus. 2. The pharmacochemical estimation of juices from the fruits of Passiflora edulis Sims. and Passiflora edulis Sims. forma flavicarpa. Planta Med., Stuttgart, $27(2): 112-21,1975$.

41. Lutomski, J. \& Wrocinski; T. - Farmakodynamiczne własciwos̄̄i preparatōw z ziela pasyflory cielistej (Passiflora incarnata L.). Wpływ składnikow alkaloidowych i flavwonoidowych na farmakodynamiczna surowca. [Pro priedades farmacodināmicas dos preparados da erva $\underline{\text {. }}$ incarnata L.. Influēncia dos componentes alcaloídi- 
cos e flavonoídicos no valor farmacodinâmico da droga]. Biul.Inst.Ros1.Lecz., (Poznan), 6 (2):176-84, 1960.

42. Makauskas, I. et a1.- Study of analytic methods in galenic preparations. I. Passiflora L. fluid extract. Rev. . Cubana Farm., Havana, 11 (1): 55-9, 1977.

43. Metcalfe, C.R. \& Chalk, L. - Anatomy of the Dicotyledons. Oxford, Clarendon Press, 1950. V. 1, p.674-80.

44. Neu, R. - Compounds contained in $\underline{\text { P.incarnata }} L$. I. Arzneim.Forsch., Aulendorf, $\underline{4}$ : 292-4, 1954.

45. Neu, R. - Compounds contained in P.incarnata L.. II. Basic compounds. Arzeim. Forsch., Aulendorf, $\underline{4}: 601-6$, 1954.

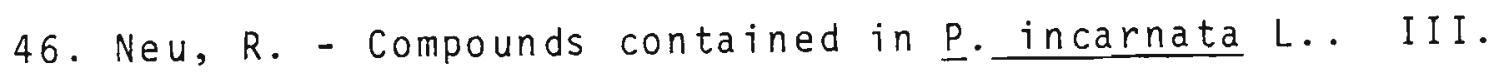
3-Methyl-4-carboline, the alkaloid of passionflower. Arzeim.Forsch., Aulendorf, $\underline{6}: 94-9,1956$.

47. Oga, S. et al. - Pharmacological trials of crude ex-

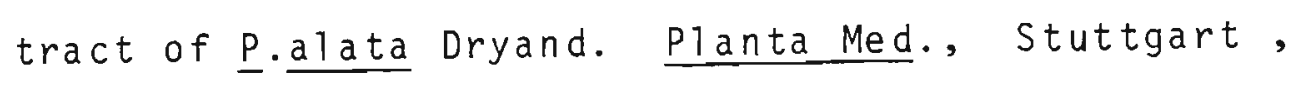
$51(4): 303-6,1984$.

48. 01 iveira, F. \& Akisue, G. - O problema da adulteração de drogas. Rev.Bras.Farm., Rio de Janeiro, 54 (2) : $71-83,1973$.

49. Penso, G. - Index Plantarum Medicinalium Totius Mundi Eorumque Synonymorum. Milano, O.E.M.F., 1984. p. $709-10$. 
50. PHARMACOPEIA dos Estados Unidos do Brasil. São Paulo, Companhia Editora Nacional, 1929. p. 574-5.

51. Prabhakar, M.C. et a 1.-Pharmacological investigations on vitexin. Planta Med., Stuttgart, 43 : 396-403, 1981 .

52. Quercia, $V$. et al. - Identification and determination of vitexin and isovitexin in P. incarnata L. extracts. J.Chromatogr., - (Amsterdam), $161: 396-402,1978$.

53. Raou1, L. et a1. - Chromaximetric investigation of cer tain psychotropic agents and their modification of the neural effects of ethyl alcool. Therapie, 19(4): 967-74, 1964. Apud. Chem.Abstr., Columbus, 63 : $7536 c, 1965$.

54. Rommelspacher, H. et al., - Harmane, a potent endogenous inhibitor of benzodrazepine receptor binding. Naunyn-Schmiedeberg's Arch.Pharmacol., 314 (1):97-100, 1980. Apud. Chem.Abstr., Columbus, $\underline{94}$ : $95729 x$, 1981 .

55. Rommelspacher, H. et al. - Is there a correlation between the concentration of $\beta$-carbolines and their pharmacodynamic effects?. Prog.Clin.Biol.Res., 90 : 41-55, 1982. Apud. Chem.Abstr., Columbus, 97 :209054t, 1982 .

56. Ruggy, G.H. \& Smith, C.S. - Chemical studies on a physiologically active substance in $\underline{\text { Pincarnata }} \mathrm{L}$. . J.Am.Pharm.Ass., Washington, 29 : 207-8, 1940. 
57. Ruggy, G.H. \& Smith, C.S. - A pharmacological study of the active principle of $\underline{\text { pincarnata }}$ L. J.Am. Pharm. Ass., Washington, 29: 245-9, 1940.

58. Sacco, J.C. - Passifloraceas. Flora Ilustrada Catari nense, Itajaī, Herbārio "Barbosa Rodrigues", 1980. $132 \mathrm{p}$.

59. Salomão, T.A. - Botānica do Maracujazeiro. In: RUGGIERo, C. - Cultura do Maracujazeiro. Jaboticabal, FCAV, 1980. p. $3-21$.

60. Schilcher, H. - Qualitätsprüfung von handelsdrogen. 4. Mitteilung: Herba Passiflorae. [Testes de qualidade de drogas do comércio. 4. Droga: Passiflora L.]. Dtsch. Apoth-Ztg., Oberurse1, 107 (25): 849-52, 1967.

61. Schilcher, H. - Flavone C-glycosides in P.incarnata L.. Z.Naturforsch., B. Tuebingen, 23 (10): 1393, 1968. Apud. Chem.Abstr., Columbus, $\underline{70}: 35080 y ., 1969$.

62. Svanidze, N. et al. - Resultados de la introduccion y estudio farmacognóstico de la p. incarnata L. en las condiciones de Cuba. Rev.Cubana Farm., Havana, $\underline{8}$ (3) : 309-14, 1974 .

63. Theodossiou, P. - Chromatographic analysis of galenic preparation of Passiflora L.. Trav.Soc.Pharm. Montpellier, Montpel1ier, 25 (1): 43-6, 1965. 
64. Thompson, W.R. - Use of moving averages and interpolation to estimate median-effective dose. Bact. Rev., $11: 115-45,1947$.

65. Ulubelen, A. et a 1. - C-glycosylflavonoids from Passiflora pittieri, P.alata Dryand., P.ambigua. J.Nat. prod., Cincinnati, 45 (6): 783, 1982.

66. Vale, N.B. \& Leite, J.R. - Efeitos psicofarmacológicos de preparações de $\underline{\text { p.edulis sims.. Cienc. Cult., } 35}$ (1) : 11-24, 1983 .

67. Zanini, A.C. \& Oga, S. - Farmacologia Aplicada. 2a ed. São Pau1o, Atheneu, 1982. 